University of Chicago Law School

Chicago Unbound

Journal Articles

Faculty Scholarship

2002

\title{
Parenthood Divided: A Legal History of the Bifurcated Law of Parental Relations
}

Jill Elaine Hasday

Follow this and additional works at: https://chicagounbound.uchicago.edu/journal_articles

Part of the Law Commons

\section{Recommended Citation}

Jill Elaine Hasday, "Parenthood Divided: A Legal History of the Bifurcated Law of Parental Relations," 90 Georgetown Law Journal 299 (2002).

This Article is brought to you for free and open access by the Faculty Scholarship at Chicago Unbound. It has been accepted for inclusion in Journal Articles by an authorized administrator of Chicago Unbound. For more information, please contact unbound@law.uchicago.edu. 


\title{
ARTICLES
}

\section{Parenthood Divided: A Legal History of the Bifurcated Law of Parental Relations}

\author{
JiLl ELAINE HASDAY*
}

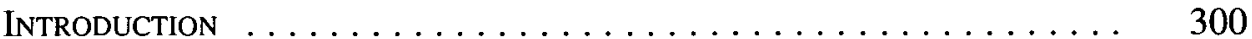

I. The Bifurcation of the Legal Treatment of Parenthood . . . . 304

A. A STARK DIVIDE IN THE LEGAL REGULATION OF PARENTHOOD EMERGES IN LATE NINETEENTH-CENTURY AMERICA $\ldots \ldots \ldots \ldots$

B. THE FIRST HALF OF THE DIVIDE: COMMON LAW PRINCIPLES AND FAMILY LAW AS IT WAS OFFICIALLY UNDERSTOOD . . . . . . . . .

C. SOCIOECONOMICS AND THE IDEAL OF DOMESTICITY IN THE

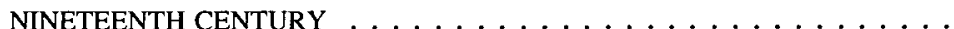

1. Domesticity, and Failed Home Life, Defined . . . . . . 319

2. The Socioeconomics of Failed Fatherhood ......... 323

II. Domestic Intervention . . . . . . . . . . . . . . . . . . . 328

A. PHILANTHROPIC INTERVENTION BETWEEN THE POOR AND THEIR

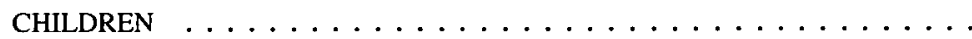

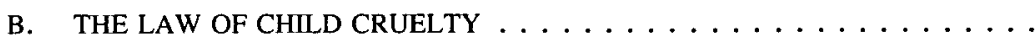

1. The New York Society for the Prevention of Cruelty to Children . . . . . . . . . . . . . . . . .

2. The Child Cruelty Movement $\ldots \ldots \ldots \ldots \ldots \ldots$

C. MOTHERS' PENSIONS $\ldots \ldots \ldots \ldots \ldots \ldots \ldots \ldots$

* Assistant Professor, University of Chicago Law School. B.A. 1994, J.D. 1997, Yale University. I would like to thank Reva Siegel, Katharine Baker, Jack Balkin, Emily Buss, Naomi Cahn, Mary Anne Case, Adrienne Davis, Allan Erbsen, Elizabeth Garrett, Jack Goldsmith, Ariela Gross, Philip Hamburger, Robert Hasday, R.H. Helmholz, Helen Hershkoff, Saul Levmore, Linda McClain, Tracey Meares, Eric Posner, Anna Marie Smith, David Strauss, Cass Sunstein, Adrian Vermeule, John Witt, Viviana Zelizer, and the participants in faculty workshops at the University of Chicago Law School, the American Society for Legal History Conference, and the fourth annual meeting of the Working Group on Law, Culture, and the Humanities. Rachel Bennett, Joan Britton, Bryan Dayton, Susan Gihring, Danielle Kemp, and the University of Chicago Law Library all provided superb research assistance. The Arnold and Frieda Shure Research Fund and the Insurance Research Fund contributed generous financial support. $(\mathcal{C} 2002$, Jill Elaine Hasday. 
III. The Modern Divide in the Legal Regulation of Parenthood . .

A. THE ENDURING BIFURCATION $\ldots \ldots \ldots \ldots \ldots \ldots \ldots$

B. THE EVASION OF CRITICAL SCRUTINY $\ldots \ldots \ldots \ldots \ldots \ldots$

C. THE NEED FOR NORMATIVE DELIBERATION $\ldots \ldots \ldots \ldots \ldots \ldots$

\section{INTRODUCTION}

The American law of parent and child is conventionally understood to be extremely deferential to parental prerogatives and highly reluctant to intervene. ${ }^{1}$ But this picture, endorsed by legal authorities and popular commentators from the nineteenth century to the present day, reflects only one tradition in the law's regulation of parenthood. Since the last quarter of the nineteenth century, there has also been massive legal intervention into the parental relation. This second legal tradition, moreover, has been guided by norms wholly different from those conventionally associated with family law, often evincing a radical suspicion of parental autonomy and an eager willingness to reshape family relations.

Consider, to take just one prominent modern example, the bifurcation between the norms and procedures that the Social Security program employs in dealing with parental relations, and those that shape Aid to Families with Dependent Children (AFDC) or its recent successor, Temporary Assistance for Needy Families (TANF). All of these programs are forms of family law, determining who counts as a family member for their purposes and regulating the legal rights and responsibilities that family members have because of this legal status. ${ }^{2}$ The Social Security program, however, is highly respectful of familial autonomy and self-government, abiding by the presumptions that the authoritative accounts of family law continue to endorse. Its laws and regulations distribute financial benefits to the spouses and dependent minor children of qualified workers, but make no attempt to determine whether recipients have properly fulfilled their familial responsibilities or to restructure a family's home life. Family members collect Social Security benefits based solely on their family status. When a parent entitled to Social Security (usually a father) dies or retires, his spouse and his dependent minor children are automatically entitled to receive Social Security payments. ${ }^{3}$ AFDC and TANF are also contemporary government programs that structure the legal rights and obligations of family members and distribute financial benefits to families with an absent or incapacitated parent, usually a father. But these programs, which overwhelmingly serve poor single mothers and their dependent minor children, routinely scrutinize the familial relations of their recipients, doubt parental judgment, and undercut

1. See infra text accompanying notes $25-54,195-200,264-84$.

2. There is a long tradition of federal family law that continues to thrive in the modern era. See Jill Elaine Hasday, Federalism and the Family Reconstructed, 45 UCLA L. REv. 1297, 1319-86 (1998). For a more extended discussion of the definition of family law, see $i d$. at 1311, 1370-73.

3. See infra text accompanying notes 270-79. 
familial autonomy. ${ }^{4}$

This Article explores how the divide in the laws and norms governing the parental relation emerged and maintained itself, tracing an important chapter in the history of the law's regulation of family life. It then uses this history to examine why the divide has survived the modern constitutional era. The sharp contrast between Social Security and AFDC or TANF is neither inevitable nor a one-time anomaly, simply the product of unique political commitments and coalitions shaping individual statutory schemes along different lines. It is a recent episode in a specific and lengthy history, part of a bifurcation in the law's treatment of parenthood that has flourished since the late nineteenth century.

It is also an example of the ways in which modern courts, in considering what equality means, have reasoned from within the very same history and structure that produced the challenged practice in the first place. Current constitutional doctrine easily holds that states can use the provision of aid to subject recipients of AFDC or TANF to forms of intervention that would never be used against recipients of Social Security. State AFDC programs, for example, were free to require home inspections as a condition of eligibility for assistance. ${ }^{5}$ State TANF programs are permitted to create strong disincentives against having children, by providing no additional aid for a child born while her mother is receiving TANF. ${ }^{6}$ Courts have protected the bifurcation between Social Security and AFDC or TANF as a matter of constitutional law. Indeed, they have made it clear that they take this type of bifurcation to be a matter of common sense, something that requires little, if any, justificatory explanation. In the process, this contemporary constitutional framework has allowed the historical divide in the law's treatment of parenthood to persist, without ever rigorously questioning whether it is consistent with basic principles of equality.

In order to uncover the principles and presumptions that have historically guided the law's bifurcated treatment of parenthood, this Article begins by considering how the bifurcation was created and sustained. This history is, in part, a record of the origins of the modern welfare state. But it is also, and more precisely, a particularly legal history about the development of new bodies of law to manage the dependency of poor people in a wage labor economy. The common law, the historical source of the noninterventionism generally ascribed to family law, was fiercely committed to upholding the household governance of the husband and father. But by the last half of the nineteenth century, many leading Americans had come to believe that this form of sovereignty was inappropriate for vast numbers of family men. These husbands and fathers were found wanting in several vital respects. Indeed, their failure was powerfully intersectional, simultaneously drawing weight from divides of class, race, and gender. As an initial matter, these men had failed to earn wages sufficient to

4. See infra text accompanying notes $225-63$.

5. See infra text accompanying notes $288-310$.

6. See infra text accompanying notes 337-49. 
keep their wives and children out of market labor, in an era that increasingly took this often unattainable goal to be the measure of both sound moral character in general and successful manhood more particularly. Moreover, and intensifying the consequences of this first set of failures, men who failed to provide for their families' entire support were disproportionately likely to be part of an ethnically or racially marginalized group, which made it more difficult for them to demand intrinsic respect as the patriarchs of their own homes.

The new legal regimes governing family relations that emerged starting in the nineteenth century were directed at these families, subjecting all their members to intense regulatory scrutiny because of the failed fatherhood of their assumed head. Like the common law, these new regimes evaluated and classified women and children in terms of their relationships with adult men. The legal treatment accorded to these presumed dependents turned on judgments about the men to whom they were or should have been attached. Family law, as it was officially described, was limited to those principles and presumptions governing families with a recognized male patriarch. These new bodies of law, for families with failed fathers, regulated the terms of parenthood. But they took their logic precisely from standing outside of what was considered to be family law.

The result was a two-part regime, implicitly understood but never fully acknowledged, that persists to the present day. After examining in Part I the legal, social, and economic forces driving the split, this Article proceeds in Part II to consider two key moments in the bifurcation of the law's treatment of parental relations. The first revolves around the Societies for the Prevention of Cruelty to Children, established in New York in 1874 and quickly spread across the nation. Focused on families in which fathers were unable to earn an income sufficient for their children's support, these societies were highly interventionist and very hostile to claims of parental right. Led by wealthy private philanthropists, they amassed unprecedented legal authority to scrutinize parental behavior, arrest parents, and remove thousands of children.

By the beginning of the twentieth century, this interventionist impulse had begun to take what would become its more prominent modern form. The second turning point in the law's bifurcation that this Article considers involves the mothers' pension laws that swept through state legislatures starting in 1911. Like the child cruelty societies, the mothers' pension programs regulated families without a viable male patriarch. Their jurisdiction was limited to families in which the father, if alive, had failed to maintain his family on his own wages, and his wife and children needed economic assistance. But the regulatory concern and reach of these programs extended beyond failed fathers alone to equally encompass the wives and mothers associated with these unsuccessful family men. When either parent in these families was at issue, the mothers' pension programs were systematically suspicious of parental judgment and eager to monitor, critique, and reshape parental behavior. The underlying norms carried over strongly from the child cruelty societies and the laws that empow- 
ered them. Only the form of the legal intervention was noticeably new. The mothers' pension programs were fully state-run. More crucially, they relied on the provision and denial of desperately needed financial aid, much more than the threat of familial separation, to accomplish their agenda.

Much of this historical record might appear vulnerable to normative scrutiny. But the divide in the law's treatment of parental relations has persisted nonetheless, and been accorded constitutional protection besides. As Part III explains, the law still uses the transfer of funds through government programs thought to signify dependency and failed fatherhood (like AFDC or TANF) as grounds for subjecting men, and the women and children associated with them, to rules that are interventionist, instrumental, and very much opposed to those that otherwise govern the legal treatment of family relations. In part, this divide in the regulation of parenthood has avoided critical attention because family law is still conventionally defined to include only those legal practices and presumptions applied to families considered financially self-sufficient (like those receiving Social Security). The bodies of law that operate to constrain or deny household autonomy are typically understood as falling solely within the jurisdiction of welfare or poverty law, even though they regulate the rights, responsibilities, and relationships of family members and thus importantly function as forms of family law as well.

More fundamentally, however, the disutility of the current constitutional framework has collapsed serious normative debate about whether particular transfers of money should be the occasion for a complete switch in the norms that the law uses to govern parental relations. Modern constitutional law is structured so that it is all but impossible to raise a successful legal challenge to government programs that condition the provision of aid to poor families on the surrender of legal and constitutional rights to privacy and autonomy that the recipient families would otherwise enjoy. This jurisprudence has protected the bifurcation in the law's treatment of parental relations with few questions, upholding the divide by accepting and reasoning within its confines.

With little room in constitutional jurisprudence to discuss or redress this dual normative regime, the issue has not been subject to sustained debate in political or popular discourse. But serious deliberation on the question is long overdue as a matter of legislative policy. The question is not what amount of welfare the government should supply, a much addressed topic. Rather, it concerns whether and to what extent the provision of welfare should change the legal rules of parenthood. Why should it be that a father's failure to provide, combined with a mother and child's call on the state for support through certain stigmatized programs, is still sufficient to subject the entire family to a completely different, and much more instrumental, set of laws and norms governing their family life? Constitutional law and legislative decision makers have hardly begun to frame that question, much less answer it. The divide in the law's treatment of parenthood is generally taken to be so commonsensical and so familiar as to obviate the need for serious explanation, even though many of the reasons 
historically offered to create and maintain the bifurcation would not persuade substantial numbers of contemporary Americans. History offers little defense for the divide in the legal regulation of parenthood. The time for serious reflection about whether and why the bifurcation should persist is long past due.

\section{The Bifurcation of the Legal Treatment of Parenthood}

\section{A. A STARK DIVIDE IN THE LEGAL REGULATION OF PARENTHOOD EMERGES IN LATE NINETEENTH-CENTURY AMERICA}

The founding of the first Society for the Prevention of Cruelty to Children marks a pivotal moment in the bifurcation of the law's treatment of parental relations. The New York Society for the Prevention of Cruelty to Children was established in New York City in 1874 by two elite reformers, Henry Bergh and Elbridge Gerry, who used the occasion of a celebrated case of physical violence against a child to create the first organization designed to combat "child cruelty" in the United States. ${ }^{7}$ Common law courts of the period staunchly protected the rights that parents in general and fathers in particular exercised over the custody and control of their children. ${ }^{8}$ But the New York society accorded almost no weight to the prerogatives of the parents it was concerned about, characterizing their connection to their children as little stronger than the ties of happenstance. Gerry explained at an organizational meeting in December 1874, for instance, that the society would "seek out and rescue from the dens and slums of the City the little unfortunates whose lives were rendered miserable by the system of cruelty and abuse which was constantly practiced upon them by the human brutes [their parents] who happened to possess the custody or control of them." Describing the homes of cruel parents as "dens and slums" offered a key clue, of course, to the limits the New York society placed on its jurisdiction. From the start, it focused on families that had not been successful in the wage labor economy, operating on the principle that this economic failure had been caused

7. See Fearful Cruelty to a Child, Evening Post (New York), Apr. 9, 1874, at 4; Mr. Bergh Enlarging His Sphere of Usefulness, N.Y. TIMES, Apr. 10, 1874, at 8; The Mission of Humanity, N.Y. TimEs, Apr. 11, 1874, at 2; Mary Ellen Wilson, N.Y. Times, Apr. 14, 1874, at 2; The Cruel Step-Mother, EvENING Post (New York), Apr. 27, 1874, at 4; Mary Ellen Wilson, N.Y. TImES, Apr. 28, 1874, at 8; Protection for Children, N.Y. Times, Dec. 17, 1874, at 3; Little Mary Ellen Finally Disposed Of, N.Y. Times, Dec. 27, 1874, at 12; Prevention of Cruelty to Children, N.Y. Times, Dec. 29, 1874, at 2.

Even before the plight of this particular child came to light in 1874, Henry Bergh, the president of the Society for Prevention of Cruelty to Animals, had been lobbied to extend his reformist concern to children. One woman, for instance, had written a public letter to Bergh in 1872 urging him to "prevent the cruelty used toward the little children in our streets," meaning specifically the cruelty of "the beggars in our streets" who used allegedly drugged children to aid in their appeals to the sympathy of passersby. The letter writer advocated placing these children "in an asylum of some kind" and imprisoning the adult beggars "where they will have to work." Cruelty to Children, N.Y. TIMEs, Jan. 27, 1872, at 3 (Letter from "A LADY WHO is DEEPLY INTERESTED" to Mr. Bergh (Jan. 24, 1872)); see also Mr. Bergh Enlarging His Sphere of Usefulness, supra (noting Bergh's presidency of the Society for Prevention of Cruelty to Animals).

8. See infra Part I.B.

9. Protection for Children, supra note 7 (emphasis added) (reporting remarks of Elbridge Gerry). 
by some crucial moral or character flaw. ${ }^{10}$

The New York society was formally a private organization supported mainly by private funds. " Some of the wealthiest and most prominent men in the nation sat on its board of directors. ${ }^{12}$ Yet reform movements in the late nineteenth century often closely intermingled elite private philanthropy and state power, ${ }^{13}$ and the New York society sought, and quickly won, tremendous

10. See infra text accompanying notes $142-49$.

11. Initially, the New York society received no money from either New York State or New York City. See, e.g., The New York Society for the Prevention of Cruelty to Children, Seventh Annual Report 7 (New York, Styles \& Cash 1882) [hereinafter The New York Society for the Prevention of Cruelty to Children, Seventh Annual Report] ("[The New York society] does not derive one dollar of aid from either the State or city; but, on the contrary, pays taxes to the latter on the building which it occupies, and in which it receives children at any hour of the day or night."). But in 1894, New York City began providing the society with an annual appropriation of $\$ 30,000$. See, e.g., Law of Feb. 14, 1894 , ch. 25, $\S 1-2,1894$ N.Y. Laws 60,60 ("To the New York society for the prevention of cruelty to children, the sum of thirty thousand dollars for the uses and purposes of said society .... The board of estimate and apportionment of the city of New York is hereby authorized to make immediate provision for the payment hereby authorized."), amended by Law of Apr. 19, 1894, ch. 336, § 2, 1894 N.Y. Laws 613, 613 (authorizing the New York City board of estimate and apportionment to provide for the payment to the New York society in 1894 "of such portion of the sum of thirty thousand dollars as herein authorized and as may be necessary for the uses and purposes of said society in said year by directing the comptroller to issue and sell revenue bonds of said city"); THE NEW YORK SOCIETY FOR THE Prevention of Cruelty to Children, Twenty-Third Annual Report 8 (New York, no publisher 1898) [hereinafter The New York Society for the Prevention of Cruelty to Children, Twenty-Third ANNUAL REPORT] ("For its legal work . . ., it receives an appropriation from the City of New York, to be applied to its uses and purposes. It does not receive anything from the City or State for the support, education, care or maintenance of the children."); THE NEW YORK SOCIETY FOR THE PREvENTION OF Cruelty to Children, Twenty-Fourth Annual Report 11 (New York, no publisher 1899) [hereinafter The New York Society for the Prevention of Cruelty to Children, Twenty-Fourth Annual Report] ('The expenses of this latter work [bringing 'violations to the attention of the courts,' asking 'that the violators be punished, and, if the case demands it, that children be taken'] have for some years been defrayed, in part only, by a small appropriation received from the City of New York ....").

12. John D. Wright, the New York society's first president, was a wealthy businessman who had made his fortune in the leather business. See John D. Wright Dead, N.Y. Times, Aug. 22, 1879, at 5. Commodore Vanderbilt, one of the richest men in America, was one of the New York society's first vice presidents. Vanderbilt's contribution was mainly financial. He reportedly told Wright: “'John, I haven't got the time to go into this thing myself, but I'll give you all the money you want." Id. The list of vice presidents also included Peter Cooper, a wealthy businessman and the founder of Cooper Union. See id.; Miriam Gurko, The Lives and Times of Peter Cooper 166-83 (1959); Edward C. Mack, Peter COOPER 243-73 (1949).

Elbridge Gerry, the guiding force behind the New York society, served first as its counsel and, after Wright's death in 1879 , as its president. He was a wealthy lawyer and investor, with an impeccable pedigree: His grandfather, of the same name, had signed the Declaration of Independence. See SYDNEY H. Coleman, Humane Society Leaders in America 66-67 (1924); Elbridge T. Gerry Dies in 90th Year, N.Y. Times, Feb. 19, 1927, at 15; Gerry's Odd Actions, CH1. TRIB., May 15, 1892, at 31 ("[Gerry] is a man of unquestioned philanthropy, a capital yachtsman, [and] the possessor of a fortune of about $\$ 10,000,000$...."); see also Elbridge T. Gerry, The Relation of Societies for the Prevention of Cruelty to Children to Child-Saving Work, in Proceedngs of the Ninth ANnual National Conference of Charities and Corrections Held at Madison, Wis., Aug. 7-12, 1882, at 127, 129 (A.O. Wright ed., Madison, Midland Publishing Co. 1883) (noting that the Societies for the Prevention of Cruelty to Children "are composed of humane persons of social position, unquestioned integrity and undoubted zeal" (emphasis added)).

13. Anthony Comstock, for instance, was an agent for the Young Men's Christian Association (YMCA), serving on its Committee for the Suppression of Vice. Established in 1872, this committee 
public authority. At the society's urging, the New York Legislature created new forms of positive law, at sharp variance with common law principles, to regulate poor families deemed pathological.

These laws authorized the intense scrutiny of family life, the frequent arrest and incarceration of parents found wanting, and the systematic institutionalization of their children. The New York society's work did not constitute the first occasion in American history in which public regulatory efforts were directed at poor families. Most notably, the Elizabethan poor laws in England had their equivalents in the early American colonies, states, and territories. ${ }^{14}$ But the New

was formed and financed by some of the same wealthy and influential New York philanthropists who served on the New York cruelty society's board. See ANNA Louise BATES, WeEdER IN THE GARDEN OF THE LoRD: ANTHONY Comstock's Life AND CAREER 62 (1995); Robert Bremner, Introduction to ANTHONY Comstock, Traps for tHE Young, at vii, xi (Robert Bremner ed., Harvard Univ. Press 1967) (1883). The next year, Comstock won public authority to implement the agenda that he had been pursuing through privately organized philanthropy. Comstock was the key lobbyist behind the 1873 federal antiobscenity law, which was popularly known as the "Comstock Act." See BATEs, supra, at 80-91; HeYwood Broun \& Margaret Leech, Anthony Comstock: Roundsman of The Lord 128-44 (1927); An Act for the Suppression of Trade in, and Circulation of, obscene Literature and Articles of immoral Use (Comstock Act), ch. 258, 17 Stat. 598 (1873). Immediately after the law was enacted, Comstock was appointed special agent of the Post Office, empowered to enforce the statute. See BATEs, supra, at 90; Broun \& LEECH, supra, at 143; Bremner, supra, at xiii.

A number of the private reform groups that organized to combat prostitution in the late nineteenth and early twentieth centuries also wielded significant influence and power within the law enforcement process. Agents for the "Committee of Fourteen for the Suppression of 'Raines Law Hotels' in New York City," which was incorporated in 1907, investigated "current vice conditions" in order to pass along their findings to law enforcement officials. Committee agents also provided police officers with personal introductions "“to probable law-breakers," "“continued with the police during the securing of the evidence," and "'later appeared in court as ... witness[es]." Willoughby Cyrus WATERMAN, Prostitution and ITS Repression in NEw YoRK CrTy, 1900-1931, at 98, 109-10 (1932) (quoting Commitee of Fourteen, AnNual Report for 1922, at 4-5); see also id. at 81 (discussing the Society for the Prevention of Crime, incorporated in New York in 1878 " "to aid in the enforcement of the laws of th[e] state" "against prostitution (quoting Society for the Prevention of Crime, Second Annual Report (1878))); Walter C. Reckless, Vice IN Chicago 254-55 (Patterson Smith Publishing Corp. 1969) (1933) (discussing the Committee of Fifteen, incorporated in Illinois in 1911 " "to aid the public authorities in the enforcement of all laws against pandering and to take measures calculated to suppress the white slave traffic'" (quoting Committee's incorporating documents)).

14. On the Elizabethan poor laws, see generally Lynn Hollen LeEs, The Solidarities of Strangers: The English Poor Laws and the People, 1700-1948 (1998); E.M. Leonard, The Early History of English Poor Relief (1900); and Paul Slack, The English Poor Law, 1531-1782 (1990). For a thorough account of the impact that the Elizabethan poor laws had on the law of California, see Jacobus tenBroek, California's Dual System of Family Law: Its Origin, Development, and Present Status (pts. 1-3), 16 Stan. L. Rev. 257 (1964) [hereinafter tenBroek, Part 1], 16 Stan. L. Rev. 900 (1964) [hereinafter tenBroek, Part 2], 17 Stan. L. Rev. 614 (1965) [hereinafter tenBroek, Part 3].

tenBroek's landmark study of California argued that the family law of that state was split in two, and identified the legal regime governing poor families in California as an almost direct modern descendant of the Elizabethan poor laws. See, e.g., tenBroek, Part 1, supra, at 257-58; tenBroek, Part 2, supra, at 978 ("[California] adheres to a pattern cut in Elizabethan England which was widely received in the American colonies and continued with little adaptation in the states."). On his account, however, the family law of California reffected a straightforward class divide, rather than a division also infused with important considerations of gender and race. In this vision, "[t]he basic motive" of the family law governing the poor in California was simply "fiscal and economic: to conserve public funds to the fullest extent possible consistent with the original undertaking." tenBroek, Part 3, supra, at 676. tenBroek did note that "racial and ethnic minorities" were among "the principal victims of poverty." 
York society was driven by a new vision of appropriate family life and domesticity that became dominant over the course of the nineteenth century. ${ }^{15} \mathrm{It}$ pursued its interventionist agenda with an unflagging energy for enforcement, a tremendous reach, and an impulse to centralize legal power in itself that the nation had never before seen in anywhere near the same dimensions.

The New York society's statute of incorporation gave it the right to call on the police for assistance, to bring complaints to court, and to provide the courts with factual information. ${ }^{16}$ It steadily built on this base. Society agents literally roamed the streets looking for instances of child cruelty, ${ }^{17}$ and they followed children back to their homes. ${ }^{18}$ By 1881 , they had won the statutory right to make arrests on their own authority. ${ }^{19}$ The society also developed a powerful role in the courts, deploying its prosecutorial power enthusiastically against thousands of parents. By the end of 1900, the year of Gerry's resignation, it had brought 52,860 criminal cases, resulting in 49,330 convictions (a $93.3 \%$ success rate) ${ }^{20}$ During the same period, the society removed 90,078 children with judicial approval. ${ }^{21}$ It exercised enormous discretion over their placement, ${ }^{22}$ and

(Women were not included on the list.) tenBroek, Part 2, supra, at 978. But he did not consider the ways in which evolving norms of appropriate family life, driven by intersecting divides of class, race, and gender, might have affected the development of family law. See infra Part I.c. tenBroek also did not examine regulatory efforts like the child cruelty societies, which in their enthusiasm to arrest parents and institutionalize children hardly operated on the premise that public funds needed to be carefully conserved (although that impulse certainly does help explain the eventual unpopularity of the cruelty societies' methods). See infra note 192 and accompanying text.

15. See infra Parts I.c, II.B.

16. See An Act for the incorporation of societies for the prevention of cruelty to children, ch. 130 , $\S \S 3-4,1875$ N.Y. Laws 114, 114.

17. See The New York Society for the Prevention of Cruelty to Children, Fourteenth Annual RePort 12 (New York, no publisher 1889) [hereinafter The New York Society for the Prevention of Cruelty to Children, Fourteenth AnNual Report] ("The work continues as in the years gone by, and the Society's officers both night and day search the slums and by-ways of this great city to save and rescue the 'neglected child'...."); The New York SocietY for the Prevention of Cruelty to Children, Nineteenth Annual Report 7 (New York, no publisher 1894) [hereinafter The New York Society for the Prevention of Cruelty to Chlldren, Nineteenth Annual Report] ("In the heat of the summer and in the storm of the winter, [the society's] officers penetrate the haunts of vice ....").

18. See The New York Society for the Prevention of Cruelty to Children, Third Annual Report 6 (New York, Styles \& Cash 1878) ("A number of degraded children have been removed from their parents. Great pains have been taken to exercise this delicate power with justice and discrimination. The children are always followed to their homes, and the exact condition of the family ascertained, whether professionals or unfortunate.").

19. See N.Y. Penal LaW $\$ 293$ (1881).

20. See The New York Society for the Prevention of Cruelty to Children, Twenty-Sixth Annual REPORT 12, 16 (New York, no publisher 1901).

21. See id. at 16.

22. See, e.g., The New York Society for the Prevention of Cruelty to Children, Seventh Annual REPORT, supra note 11 , at 6 (noting that the society's "aid is invoked in placing the children it rescues with the proper institutions or persons, to whom their permanent care is assigned"). Indeed, an 1886 New York statute provided that courts could appoint the New York society to serve as a child's guardian. See An Act to amend chapter one hundred and thirty of the laws of eighteen hundred and seventy-five entitled "An act for the incorporation of societies for the prevention of cruelty to children," ch. $30, \S 1,1886$ N.Y. Laws $38,38$. 
put the overwhelming majority in institutions. ${ }^{23}$ Once a child had been removed from her parents at the New York society's instigation or with its help, the courts were extremely reluctant to allow visitation or to release the child, unless the society agreed. ${ }^{24}$

The New York society's work, examined in more detail in Part II, constitutes a crucial episode in the creation of two sets of normative and legal systems for governing the parent-child relation. The rest of this Part places that bifurcation in historical context. First, to make clear the sharpness of the divide that emerged in the nineteenth century's legal treatment of parental relations, it

23. The New York society's first annual report recorded the "Disposition made of [72] Children at the instance of the Society." The New York Society for the Prevention of Cruelty to Children, First Annual Report 45 (New York, Styles \& Cash 1876) [hereinafter The New York Society for the Prevention of Cruelty to Children, First AnNual Report]. Eight $(11.1 \%)$ children had been placed in homes or "situations" (presumably apprenticeships or domestic service), 11 (15.3\%) were lost or stolen children who were returned to their parents, and $53(73.6 \%)$ were institutionalized. Id. The society followed that pattern consistently. Its third annual report, for instance, recorded the disposition of 461 children removed from their parents during 1877 . Twenty-six $(5.6 \%)$ had been placed in homes or situations, $58(12.6 \%)$ were lost, stolen, or strayed children who were returned to their parents, and 377 (81.8\%) were institutionalized. See The New York Society for the Prevention of Cruelty to ChILDREN, supra note 18, at 66 .

The New York society did promise from the start, however, that it had no intention of attempting to convert Catholic children by placing them in Protestant institutions. The Catholic Church had accused the Children's Aid Society of this practice, and the New York cruelty society was eager to avoid that controversy. See, e.g., Prevention of Cruelty to Children, supra note 7 ("It was unjustly intimated that the society was got up in favor of the Protestant sects, and that it was to interfere with the religion of Roman Catholic children.... He, as counsel, would place all Roman Catholic Children in Roman Catholic institutions." (reporting remarks of Elbridge Gerry)); ConstrTution AND By-Laws of the NEw York Society for the PRevention of CRUELTY to ChILDREn 7 (New York, no publisher 1875) ("[This society] proposes to labor in the interest of no one religious denomination ...."); THE NEw YORK Society for the Prevention of Cruelty to Children, First Annual Report, supra, at 27 ("[The society's] officers have in every case endeavored to ascertain the religious faith of the parents of the child, informed the Court thereof, and urged the commitment of the child 'to an institution governed or controlled by officers or persons of such religious faith as far as practicable."' (quoting ch. 173, \& 2, 1875 N.Y. Laws)); The New York Society for the Prevention of Cruelty to Children, Tenth AnNual RePort 13 (New York, no publisher 1885) [hereinafter The New York Society for the Prevention OF Cruelty to Children, Tenth Annual Report] ("[The society] labors, side by side, and harmoniously with the other institutions, irrespective of creed; for all religious denominations are represented in its Board of Directors, and its work is entirely unsectarian.").

24. See, e.g., People v. Giles, 46 N.E. 326, 326-28 (N.Y. 1897) (finding for society in case where mother had lost custody on charge that she was running a brothel and society refused to surrender children after mother was acquitted in criminal trial); In re Diss Debar, 3 N.Y.S. 667, 669 (Sup. Ct. 1889) ("The president of the [New York society] stated . . that the effect upon the children of allowing Madam Diss Debar to visit them at the present time would be exceedingly injurious. Under these circumstances, I am constrained to decline to make any order permitting her to see such children."); Homer Fol.ks, The Care of Destrtute, Neglected, and Delinquent Children 175 (1907) ("This society thus became, by 1890 , the factor which actually controlled the reception, care, and disposition of destitute, neglected, and wayward children in New York city, thus practically controlling the lives of an average number of about fifteen thousand children ....”); The New York SOCIETY FOR THE PREvention of Cruelty to ChILdRen, Twenty-Third Annual Report, supra note 11 , at 8 ("[The society] defends the custody of children in institutions committed through its instrumentality, when assailed upon habeas corpus, without expense to the [institution housing the child]; and in the event of adverse decisions (which rarely occur), prosecutes appeals therefrom to the appellate tribunals of the State."). 
reviews the common law principles of parenthood that courts and authoritative legal writers continued to promulgate throughout the century, principles grounded in deference to paternal autonomy. It then analyzes the social and economic forces that helped convince many leading nineteenth-century Americans that common law rules and norms could not govern vast numbers of families, that new bodies of law had to be created outside the official jurisdiction of family law because many families had no patriarch worthy of the public's deference.

\section{B. THE FIRST HALF OF THE DIVIDE: COMMON LAW PRINCIPLES AND FAMILY LAW AS IT WAS OFFICIALLY UNDERSTOOD}

Throughout the nineteenth century, the common law of parent and child remained devoted to protecting the household governance of husbands and fathers. As Part II will discuss, growing numbers of prominent citizens came to believe during this period that many husbands and fathers were unworthy of this form of self-sovereignty. America, more and more dominated by the wage labor economy, had increasingly come to define successful adult masculinity as the ability to support an entire family on one's own paycheck, keeping wife and children out of market labor and in a home of some comfort. This standard was unattainable for large numbers of fathers in the nineteenth century, and the failures were concentrated among the working class and the ethnically or racially disfavored, whose claims to public respect as the heads of their own households were more tenuous to begin with. In response, reformers and lawmakers developed new forms of law specifically and self-consciously targeted at populations they believed were characterized by failed fatherhood and failed domesticity. These laws placed far less value on familial autonomy, authorized much greater intervention into parental relations, and enthusiastically contemplated the reshaping of family life.

Common law courts and commentators never acknowledged these legal developments of the nineteenth century, however, much less considered them a threat to common law norms and rules. The principles that the new bodies of law applied to family relations were diametrically opposed to those that governed the common law. But all of this new activity took place outside of what was officially considered family law. Indeed, the governing logic behind the new legal regimes revolved precisely around the understanding that they regulated families that were outside the confines of family law because of the failure at their head. Family law, as it was authoritatively defined, was limited to the historical rules and norms that still applied to families with an acknowledged patriarch.

Over the course of the nineteenth century, the divide between official family law and the new legal rules governing the family relations of assumed social deviants became increasingly stark. This section considers the first half of that divide, examining the fierceness and consistency with which common law courts and commentators protected the prerogatives of successful fathers throughout the nineteenth century. To help make that point, the section takes the 
common law on a father's rights of custody and correction as illustrative examples.

The Anglo-American common law understood the connection between parent and child as a relation of both reciprocal obligation and hierarchical obedience. At common law, a father enjoyed an almost absolute right to the custody, labor, and earnings of his minor children ${ }^{25}$ and was in turn expected to maintain, protect, and educate them. ${ }^{26}$ In order to secure his child's obedience, a father was entitled to "correct" his child using physical punishment. Middle-class Americans' views on the legitimacy of child labor reversed over the course of the nineteenth century, so that the once accepted practice became a mark of unfit parenthood and failed home life. ${ }^{27}$ But the premise that a father who protected, supported, and educated his children was entitled to very powerful rights of custody and control persisted. Throughout the nineteenth century, common law courts and legal treatises defended these paternal prerogatives in explicitly authoritarian terms, defined their scope broadly, and enforced legal doctrines that radically diminished the possibility of legal intervention to disrupt the exercise of paternal power.

William Blackstone's Commentaries on the Laws of England (1765) set the tone of deference to a father's rule over his household. As Blackstone reported the common law's reasoning, a father had rights over his children "partly to enable [him] more effectually to perform his duty, and partly as a recompence for his care and trouble in the faithful discharge of it."28 Once a father was fulfilling his obligations to his children, however, his prerogatives were tremendous. In Blackstone's apt phrase, children lived in "the empire of the father" until they reached twenty-one. ${ }^{29} \mathrm{~A}$ father enjoyed virtually unlimited control over the custody of his minor legitimate children and was also free to determine who would serve as his children's guardian in the case of his death, unconstrained by any obligation to select the children's mother, for instance, or another relative ${ }^{30}$ Blackstone's description of the right of correction, operating on similar principles, noted that a father had to act "in a reasonable manner," but left the exact location of this limit unclear. Blackstone endorsed correction for the purpose of securing obedience; the only behavior he actually declared unreasonable was intentionally killing a child for insubordination. As he explained:

The ancient Roman laws gave the father a power of life and death over his children; upon this principle, that he who gave had also the power of taking away....

25. See 1 William Blackstone, Commentaries *441; 2 James Kent, Commentaries on American LaW 254-55 (O.W. Holmes, Jr. ed., Boston, Little, Brown, \& Co. 12th ed. 1873).

26. See 1 BlaCKStONE, supra note 25 , at *434-40; 2 KENT, supra note 25 , at 225-52.

27. See infra text accompanying notes $62-69$.

28. 1 BLACKSTONE, supra note 25 , at *440. As Blackstone noted, "a mother, as such, [was] entitled to no power, but only to reverence and respect." $I d$. at $* 441$.

29 . Id. at $* 441$.

30. See id. 
The power of a parent by our English laws is much more moderate; but still sufficient to keep the child in order and obedience. He may lawfully correct his child, being under age, in a reasonable manner; for this is for the benefit of his education. ${ }^{31}$

Blackstone's account, faithfully translated for an American audience in James Kent's Commentaries and other treatises, proved extremely influential. ${ }^{32}$ Over the entire course of the nineteenth century, common law courts and legal writers in the United States remained highly respectful of the control that parents, particularly fathers, exercised over their households and children, and committed to doctrines that made legal intervention to counter parental excess or abuse very unlikely.

The common law, for instance, remained determined to protect parental rights of custody. The child cruelty societies that spread rapidly across the nation in the last quarter of the nineteenth century may have enthusiastically deprived biological parents of custody over children that they had raised from birth and treated biological parenthood as hardly more than a mere accident. But all of this legal intervention and lack of deference was directed at families without a father able to support his wife and children and keep them out of market labor. ${ }^{33}$ In the same years that saw the rise of the child cruelty societies, the nineteenthcentury courts and treatise writers describing and developing the common law shared and enforced Blackstone's assumption that the custodial prerogatives of biological parents almost always trumped the claims of anyone else (although they did help steadily improve the position that mothers occupied in interspousal custody battles). ${ }^{34}$

31. Id. at $* 440$.

32. For instance, Kent's description of a father's right of correction, first published in 1826, followed Blackstone closely:

[T] he Romans, according to Justinian, exceeded all other people, and the liberty and lives of the children were placed within the power of the father.... When the crime of exposing and killing infants was made capital, under Valentinian and Valens, then the practice was finally exterminated, and the paternal power reduced to the standard of reason and of our own municipal law, which admits only the jus domesticoe emendationis, or right of inflicting moderate correction, under the exercise of a sound discretion.

2 Kent, supra note 25, at 253-54; see also Charles E. Chadman, Personal Rights and Domestic RELATIONS 115 (Chicago, Henneberry Co. 1899) ("At the ancient Roman law the father had the power of life and death over his children.... The English common law, while recognizing the power of the parent to correct the child, reduced the power to that sufficient to keep the child in order and obedience.").

33. See infra Part II.B.

34. Mothers seeking custody in interspousal disputes fared best when the children at issue were very young, or ill, or female. See, e.g., Anonymous, 55 Ala. 428, 432-33 (1876) ("All must feel, that no greater calamity can befall an infant daughter, than a deprivation of a mother's care, vigilance, precept and example.... Therefore, courts are reluctant now to deprive her of the custody of her infant daughters, and but seldom, if ever, do so, unless misconduct is imputable to her."); McKim v. McKim, 12 R.I. 462,464 (1879) ("The welfare of the child, considering her tender age, her sex, and the delicacy of her constitution, will, in our opinion, be best subserved by leaving her for the present with her 
Nineteenth-century judges and legal writers conceded that common law courts could rule against the custodial claims of parents "when the morals, or safety, or interests of the children strongly require[d] it." ${ }^{35}$ But they stressed that it was "not enough to consider the interests of the child alone." "[D]ue weight" had to "always be given to the legal rights of the father." ${ }^{37}$ In virtually every case, this meant that a father who was not "plainly" unable or unwilling to discharge his basic parental duties had "a paramount right to the custody of his infant child, which no court [was] at liberty to disregard." 38 As one state supreme court summarized the premise guiding nineteenth-century custody decisions at common law, "it would not do" to deprive a biological parent of his custodial authority simply because his children were, "in the ordinary estimation, ... neglected, and ... the popular verdict would declare that they would be better off, and stand a better chance of becoming useful members of society, if they were removed from the pernicious influence of their parents." ${ }^{39}$ A biological parent could only lose custody for behavior that was "sufficiently extravagant and singular and wrong to meet the condemnation of all decent and law-abiding people. $" 40$

Given this legal standard, common law custody disputes challenging the claims of a biological parent in the nineteenth century clustered around a narrow set of circumstances. A biological parent who was raising his child in his household faced little risk that a common law court would deprive him of custody in favor of a third party. The typical custody battle that these courts adjudicated between biological parents and third parties involved "third parties" who had been raising the child for some time and were biologically related to the child as well. Courts occasionally granted these surrogate parents legal custody, ${ }^{41}$ but their chances were greatest where the biological parent had

mother ... ."); id. at 465 ("[I]f the child here, instead of being a girl, were a boy of somewhat riper age, in good health, we might deem it our duty under the law to restore him to his father, even at the risk of tearing the mother's heartstrings asunder.'); JAMEs SCHOULER, A TREATISE ON THE LAW OF THE DOMESTIC Relations 338 (Boston, Little, Brown, \& Co. 1870) ("The rule as to legal preference [with respect to child custody] is essentially that of the common law, with, however, an increasing liberality in favor of the mother; strengthened, in no slight degree, by positive legislation."); Walter C. Tiffany, HandBook on the Law of Persons and Domestic Relations 250-51 (St. Paul, West Publishing Co. 1896) ("A child of very tender years needs the care and attention of a mother ... . It can only be in such cases as this, where the child, from its extreme youth or sickness, needs a mother's care, that the court can deprive the father of the right to the child's custody ....").

35. 2 KENT, supra note 25, at 254-55.

36. Verser v. Ford, 37 Ark. 27, 30 (1881).

37. TIFFany, supra note 34 , at 248.

38. State v. Richardson, 40 N.H. 272, 275 (1860); see also SCHOULER, supra note 34, at 339 (noting that "[t]he father has then, in America, the paramount right of custody independently of all statutes to the contrary," although "this paramount right may be forfeited by his misconduct").

39. Lovell v. House of the Good Shepherd, 37 P. 660, 661 (Wash. 1894).

40. Id.

41. In almost all of the cases I found, three factors were present when a common law court awarded custody to a third party instead of a biological parent: (1) the third party had been raising the child in his household for a substantial period of time, either with the parent's consent or because the parent had 


\section{waived his parental rights or had allowed his relationship with his child to lapse for a number of years before attempting to reassert control. ${ }^{42}$}

totally abandoned his responsibilities; (2) the third party was biologically related to the child; and (3) the biological parent was claiming custody singly rather than jointly with the other parent, usually because the other biological parent was dead. See, e.g., In re Vance, 28 P. 229, 230-31 (Cal. 1891) (awarding custody to maternal grandmother who had raised children rather than widowed father who had abandoned and ceased supporting them); Estate and Guardianship of Linden, 1 Myrick Prob. 215, 216-21 (Cal. Prob. Ct. 1878) (awarding custody to maternal aunt rather than widowed father who had given aunt the child to raise at nine months); Smith v. Bragg, $68 \mathrm{Ga}$. 650, 651-53 (1882) (awarding custody to maternal uncle who had raised and supported child rather than widowed father who had abandoned child); Bryan v. Lyon, 3 N.E. 880, 880-86 (Ind. 1885) (awarding custody to maternal uncle and aunt who had raised and supported children rather than widowed father who had abandoned them); Bonnett ex rel. Newmeyer v. Bonnett, 16 N.W. 91, 92-93 (Iowa 1883) (awarding custody to paternal grandparents rather than widowed mother who had given grandparents the child to raise when child was two months old); Drumb v. Keen, 47 Iowa 435, 435-38 (1877) (awarding custody to maternal grandparents rather than widowed father who had given grandparents the child to raise when child was three); Chapsky v. Wood, 26 Kan. 650, 654-58 (1881) (awarding custody to maternal aunt rather than father (possibly widowed but definitely not living with wife) where parents had given aunt the child to raise at birth); Sturtevant v. State ex rel. Havens, 19 N.W. 617,617-19 (Neb. 1884) (awarding custody to maternal grandparents rather than widowed father who had given grandparents the child to raise at birth); In re Schroeder, 65 How. Pr. 194, 195-98 (N.Y. Sup. Ct. 1883) (awarding custody to paternal aunts rather than widowed mother who had agreed aunts would raise the children); Commonwealth $e x$ rel. Goerlitz v. Barney, 4 Brewster 408, 409-13 (Pa. Ct. Com. Pl. 1872) (awarding custody to maternal grandmother who had been raising the child rather than widowed mother); Sheers v. Stein, 43 N.W. 728, 729-31 (Wis. 1889) (awarding custody to paternal aunt who had been raising child rather than widowed father who had never contributed to the child's support, manifested aversion toward the child, and expressed the belief that he was not the child's biological father).

Less frequently, courts ruled in favor of the custodial claims of a third party who had been raising a child but was not biologically related to the child. See, e.g., Washaw v. Gimble, 7 S.W. 389, 389-90 (Ark. 1888) (awarding custody to member of widowed father's church congregation who had raised child from birth at father's request rather than to father who now demanded custody); People ex rel. Curley v. Porter, 23 Ill. App. 196, 196-99 (1887) (awarding custody to couple who had raised and supported child at widowed father's request rather than to father who had agreed that couple could keep child until adulthood but now demanded custody).

42. In State v. Richardson, for instance, the Supreme Court of New Hampshire awarded a widowed biological father custody of his ten year-old daughter, against the claims of a maternal uncle and his family who had raised the child for most of her life. See 40 N.H. at 275-82. The court stressed that "there [was] no evidence of the unfitness of the father for the proper discharge of his parental duties toward the child, or of the want of proper parental affection," id. at 276, finding that the father had never agreed to give the uncle custody and had never, "in any way, waived or abandoned his parental rights or duties," id. at 279. For other examples where a biological parent was awarded legal custody against the claims of a third party who had raised the child for a significant period of time, see People ex rel. Trainer v. Cooper, 8 How. Pr. 288, 291-97 (N.Y. Sup. Ct. 1853) (awarding custody to widowed father, a free black man, who was claiming his daughter from a woman who had been raising the girl, on ground that "the father has a title superior to any stranger"); Armstrong v. Stone, 50 Va. (9 Gratt.) $102,102-08$ (1852) (awarding custody to widowed mother rather than paternal grandfather who had been raising the child, on ground that "the mother was entitled to the custody as her legal right" and had not "impair[ed] her right to the custody" by temporarily leaving her child with the child's grandfather while she worked to support herself); Lovell, 37 P. at 660-62 (holding that widowed mother had legal right to custody of child that she had placed in charitable institution for raising but now wanted back); and Rust v. Vanvacter, 9 W. Va. 600,602,612-15 (1866) (awarding custody to widowed father rather than maternal grandmother who had been raising child, on ground that father had the preeminent right to his child and had never waived or abandoned his parental rights). See also Henson $v$. Walts, 40 Ind $170,171-73$ (1872) (awarding custody to widowed father who had placed child in care of unrelated 
The bifurcation that emerged in the law's treatment of parenthood is perhaps easiest to see in the custody context, where common law courts diligently protected and reinforced a biological parent's right to custody at the same moment that the child cruelty societies were extremely willing, even eager, to scrutinize familial relations, undercut parental autonomy, and deprive biological parents of custody. But the common law right of correction also provides an illuminating juxtaposition to the norms of intervention and suspicion that governed the work of the child cruelty societies and their successors, even if the divide in the law of parenthood is somewhat less obvious here. As we will see, the cruelty societies and the programs that followed in their tradition never focused on preventing the physical abuse of children, even where failed fathers and their families were concerned. ${ }^{43}$ Yet the case law and legal scholarship on the common law right of correction nevertheless help reveal the commitment that the common law maintained in the nineteenth century to protecting and upholding a father's household government, simply because those common law norms were never stated and defended more clearly than in this context.

Tapping Reeve, author of the first family law treatise published in the United States, acknowledged some limit on a father's right of correction. But Reeve, more explicitly than even Blackstone, left determining "the bounds of moderation" almost entirely to a father's own discretion. ${ }^{44}$ His Law of Baron and Femme (1816) explained that a "parent"-and here Reeve certainly was not envisioning a married woman stripped of her civil identity by common law coverture-operated as a sovereign within his own realm, subject to state intervention only in clear cases of malicious intent. ${ }^{45}$ " $[\mathrm{T}]$ he parent ought to be considered as acting in a judicial capacity, when he corrects; and, of course, not liable for errors of opinion," Reeve instructed. "[A]lthough the punishment should appear to the triers to be unreasonably severe, and in no measure proportioned to the offence; yet, if it should also appear, that the parent acted conscientiously, and from motives of duty, no verdict ought to be found against him.,"46

As intended, the legal protection accorded to a parent's right of correction at common law discouraged prosecution. In contrast to all the legal activity that

couple for a year and then had couple attempt to gain legal custody); and Hutson v. Townsend, 27 S.C. Eq. (6 Rich. Eq.) 249, 249, 253-54 (Ct. App. 1854) (awarding custody pending the resolution of a lawsuit over permanent placement to widowed father rather than maternal aunt who had been raising child, on ground that "the natural right of the father to the custody of his child did not appear to be infringed by misconduct on his part, or by consequential injury to the interests of the child").

43. See infra text accompanying notes $128-34,168$.

44. Tapping Reeve, The Law of Baron and Femme 288 (New Haven, Oliver Steele 1816).

45. At common law, a married woman had little or no right to own property, contract, file suit, keep her own earnings, or claim custody of her children. See NORMa BasCH, IN THE EYES OF THE LAw: WOMEN, Marriage, and Property in Nineteenth-Century New York 17, 51-55 (1982); Michael Grossberg, Governing the Hearth: Law and the Family in Nineteenth-Century America 25 (1985); Elizabeth Bowles Warbasse, The Changing Legal Rights of Married Women, 1800-1861, at 7-21 (1987); Richard H. Chused, Married Women's Property Law: 1800-1850, 71 Geo. L.J. 1359, 1365-68 (1983).

46. ReEve, supra note 44, at 288. 
the Societies for the Prevention of Cruelty to Children generated, the common law courts, addressing families with a recognized patriarch, had cause to consider a parent's right of correction in just a handful of cases in the nineteenth century. These courts modified the common law only marginally, retaining the historical commitment to supporting a father's governance of his children. Indeed, a minority of jurisdictions, hearing cases that arose largely in the $1870 \mathrm{~s}$ and 1880 s (the very years the child cruelty societies emerged on the scene), adopted a stance virtually identical to the one that Reeve had articulated at the beginning of the century. This position, most prominently advanced in a series of North Carolina Supreme Court decisions, held "that so long as the parent acts in good faith and without malice," which was the legal presumption, "the criminal law will not interfere with him however severe or unmerited the punishment, unless it produces permanent injury."47

The North Carolina Supreme Court explained its noninterventionism (or, more accurately, its decision to staunchly protect parents from prosecution) in a language of parental sovereignty particularly adapted for the American context and particularly powerful in a Southern state after the Civil War. The family, in this view, occupied a role analogous to that of a state in the federal system of government. " $[\mathrm{F}] \mathrm{amily}$ government [was] recognized by law as being as complete in itself as the State government is in itself, and yet subordinate to it. ${ }^{,{ }^{\prime} 8}$ Like the states, a family needed and enjoyed vast discretion to govern its own affairs. Conflicts within the family were to be resolved internally, with the explicit understanding that the parent's (particularly the father's) will would

47. 1 Joel Prentiss Bishop, New Commentaries on the Criminal Law 531 (Chicago, T.H. Flood \& Co. 8th ed. 1892). For examples of decisions adopting this position, see Dean v. State, 8 So. 38,39 (Ala. 1890) ("He must not only inflict on the child immoderate chastisement, but he must do so malo animo,-with legal malice or wicked motives; or else he must inflict on him some permanent injury .... [T] [Te parent, as to such matters of discipline, exercises pro hac vice judicial functions ...."); Neal v. State, $54 \mathrm{Ga} .282,283$ (1875) ("[A] very large margin must be left to the judgment of the parent . ..."); State v. Jones, 95 N.C. 588 (1886) (discussed infra text accompanying notes 48-49); and State v. Alford, 68 N.C. 300,302 (1873) ("[A]s it appeared that the chastisement was for the misconduct of the boy, ... and the injury did not, nor was it in its nature, calculated to produce lasting injury to the boy, it did not exceed the limits of the power granted to the defendant . ...").

For analogous reasoning in cases ruling on a teacher's right to physically correct a student, see Boyd v. State, 7 So. 268, 269 (Ala. 1890) ("[A] teacher is often said pro hac vice to exercise judicial functions .... [But] [h] cannot lawfully disfigure [his student], or perpetuate on his person any other permanent injury.... [and a teacher cannot lawfully correct when] induced by legal malice, or wickedness of motive ...."); State v. Pendergrass, 19 N.C. (2 Dev. \& Bat.) 348, 350 (1837) ("His judgment must be presumed correct, because he is the judge.... [But] [i]f he use his authority as a cover for malice, and under pretence of administering correction, gratify his own bad passions, the mask of the judge shall be taken off . ..."); Commonwealth v. Seed, 4 AM. L.J. 137, 138 (Ct. C.P. Phila. 1852) ("[T]he parent ought to be considered as acting in a judicial capacity, when he corrects; and, of course, not liable for errors of opinion .... [I]f it should ... appear that the parent acted conscientiously, and from motives of duty, no verdict ought to be found against him."); and Anderson v. State, 40 Tenn. ( 3 Head) 455, 457 (1859) ("[T]he legal presumption is, that the chastisement was proper ... To hold a parent bound to prove that he had good cause to whip his child, or be subject to a conviction upon indictment, would be monstrous. The same rule applies to the relation under consideration.").

48. Jones, 95 N.C. at 592 (quoting State v. Rhodes, 61 N.C. (Phil. Law) 453, 456 (1868)). 
control. As the court warned, allowing a jury to convict whenever it found that a parent had inflicted "cruel and excessive" punishment "would tend, if not to subvert family government, greatly to impair its efficiency, and remove restraints upon the conduct of children."49

While a majority of common law courts in the nineteenth century formally adopted a legal doctrine on correction that was slightly more liberal than the North Carolina rule, they too remained firmly noninterventionist and committed to protecting a father's sovereignty over his offspring. These courts held that a father could only inflict moderate correction on his children; if his chastisement was excessive (a question for the jury), no showing of malice or of permanent injury was necessary to convict. ${ }^{50}$ In practice, though, the presumption that a

49. Id. at 590. The North Carolina court also supplemented its authority-based rationale for upholding a father's household government with newer privacy considerations, predicting that forcing a father-defendant "to lift the curtain from the scenes of home life, and exhibit a long series of acts of insubordination, disobedience and ill-doing ... would open the door to a flood of irreparable evils far transcending that to be remedied by a public prosecution." Id. The most interesting aspect of this appearance of privacy discourse, however, is how much of a rarity such discourse was. Some scholars have assumed that nineteenth-century common law authorities deferred to parental prerogatives of correction out of a "belief in the privacy of the family." Elizabeth Pleck, Domestic Tyranny: The Making of Social Policy Against Family Violence from Colonial Times to the Present 75 (1987). Yet such presumptions are quite ahistorical. Privacy arguments began to dominate the jurisprudence on wife beating in the late nineteenth century, as feminist agitation and cultural celebrations of companionate marriage made authoritarian rationales for nonintervention seem less and less persuasive in that context. See Reva B. Siegel, "The Rule of Love": Wife Beating as Prerogative and Privacy, 105 YALE L.J. 2117, 2150-74 (1996). The North Carolina Supreme Court played a leading role in this case law on the marital relation, one reason it may have thought to insert an argument from privacy into a decision on a parent's prerogatives that generally focused on parental authority. See Rhodes, 61 N.C. (Phil. Law) at 459 ("[It] is not, that the husband has the right to whip his wife . . ; but that we will not interfere with family government in trifling cases .... We will not inflict upon society the greater evil of raising the curtain upon domestic privacy, to punish the lesser evil of trifling violence."). But to my knowledge, no other common law court in the nineteenth century reasoned about a parent's right of correction in the idiom of privacy. Instead, these courts still took authoritarian accounts of parenthood to be fully convincing and grounded their explanations for nonintervention on explicit endorsements of the subordination of children to their parents.

50. See Fletcher v. People, 52 Ill. 395, 397 (1869) ("It would be monstrous to hold that under the pretense of sustaining parental authority, children must be left, without the protection of the law, at the mercy of depraved men or women, with liberty to inflict any species of barbarity short of the actual taking of life."); Hinkle v. State, 26 N.E. 777, 778 (Ind. 1891) ("The father has the right to administer proper and reasonable chastisement to his child without being guilty of an assault and battery, but ... if he does administer unreasonable chastisement, and treats the child cruelly and inhumanly, his acts become unlawful, and, if they ... constitute an assault and battery, he may be prosecuted ...."); Hombeck v. State, 45 N.E. 620, 620 (Ind. App. 1896) ("The law is well settled that a parent has the right to administer proper and reasonable chastisement to his child without being guilty of an assault and battery; but he has no right to administer unreasonable or cruel and inhuman punishment."); State v. Bitman, 13 Iowa 485, 486 (1862) ("It is the right of a parent to chastise his child, but when such chastisement amounts to cruelty or inhumanity, or where, as the court below charged the jury, the parent or master goes beyond the line of reasonable correction, his conduct becomes more or less criminal."); State v. Washington, 29 So. 55, 55 (La. 1900) ("Whether a parent who inflicts corporal punishment on a child is acting 'in good faith, prompted by parental love, without passion,' is a matter which may be determined [by the jury] largely from the character of the injuries received by the child...."); Commonwealth v. Blaker, 1 Brewster 311, 311-12 (Ct. Quarter Sessions Phila. 1867) ("[P]arent[s] must exercise reasonable judgment and discretion, and be governed as to the mode and severity of the 
father's correction had been within the bounds of his authority remained extremely difficult to overcome. Successful prosecutions were rare, ${ }^{51}$ and they targeted defendants who might have tested even North Carolina's generous deference (like the father who doused his blind son with kerosene and locked him in an unheated cellar). ${ }^{52}$ As these courts explained, "[t]he right of parents to chastise their refractory and disobedient children, is so necessary to the government of families and to the good order of society," that no one would think "of interfering with its existence, or of calling upon [parents] to account for the manner of its exercise upon light or frivolous pretences." 53 "The authority to govern must rest in some one, and the law has placed that power in the hands of the father as the head of the family. His right to exercise such authority in moderation and justly will not be denied." 54

The next section considers the social and economic forces that helped

punishment by the nature of the offence, the age, size, and apparent powers of endurance of the child, and it is for the jury to decide whether the punishment was excessive."); Johnson v. State, 21 Tenn. (2 Hum.) 283,283 (1840) ("In chastising a child, the parent must be careful that he does not exceed the bounds of moderation, and inflict cruel and merciless punishment; if he do, he is a trespasser, and liable to be punished by indictment."); Stanfield v. State, 43 Tex. 167, 168 (1875) ("Whether it is moderate or excessive must necessarily depend upon the age, sex, condition, and disposition of the child, with all the attending and surrounding circumstances, to be judged of by the jury . ...); 17 THE AMERICAN AND ENGLISH ENCYCLOPÆDIA OF LAW 362 (John Houston Merrill ed., Northport, Edward Thompson Co. 1892) ("In assertion of this right of control the law gives the parent the right of moderate correction of his child in a reasonable manner; and the courts are reluctant to interfere in matters of family discipline."); G.W. Field, The Legal Relations of Infants 66 (Rochester, Williamson \& Higbie 1888) ("The parent may lawfully correct or chastise his child, being under age, in a reasonable manner; but he cannot inflict a cruel and excessive punishment; and the question of excess of punishment is one for a jury."); 1 EmLIN McClain, A Treatise on the Criminal Law 206 (Chicago, Callaghan \& Co. 1897) ("There are various relations in life which make some degree of violence or restraint under proper circumstances lawful. Thus, moderate restraint or correction may be employed by the parent, or by one in loco parentis. But if such correction or restraint is unreasonable it constitutes an assault."); W.C. RoDGERS, A TREATISE ON THE LAW OF Domestic Relations 419 (Chicago, T.H. Flood \& Co. 1899) ("[A parent has] the right to inflict such bodily punishment or chastisement as is reasonably necessary to compel a dutiful and proper respect for and obedience to the parental authority .... [S]o long as the parent exercises proper moderation, there is no criminal liability for chastising his child.").

51. For four examples, see Hinkle, 26 N.E. at 778 (affirming father's conviction for assault and battery where father "fasten[ed]" his twelve year-old daughter "to a sewing-machine by a chain attached to the girl's ankle, and allow[ed] her to remain chained during the day, except at meal-times, and ... at bed-time"; the girl was found "thus chained in the house, with her little brother, about two or three years old, there being no older person at the house"); Hornbeck, 45 N.E. at 620 (affirming father's conviction where "[t]he assault and battery was committed upon the person of the appellant's own son, a lad of 13 years, by striking him a number of times with a buggy whip"); Commonwealth v. Coffey, 121 Mass. 66, 66, 69 (1876) (holding that jury lawfully convicted father of assault and battery "upon the ground that [he and his co-defendants] used force which was excessive and unjustifiable in the sick condition of the daughter" or upon the ground that the defendants' "acts were not done in the exercise or support of the rightful authority of the father, but in the execution of a scheme of the [father's lawyer], and under [the lawyer's] direction and control only"); and Blaker, I Brewster at 311-12 (reporting that jury convicted mother of assault and battery upon her child, but found defendant not guilty of assault and battery with intent to kill).

52. See Fletcher, 52 Ill. at 396-97.

53. Johnson, 21 Tenn. (2 Hum.) at 283.

54. Smith v. Slocum, 62 Ill. 354, 358 (1872). 
convince leading American reformers and lawmakers in the nineteenth century that many of the nation's husbands and fathers did not merit the protection and deference that the common law continued to so copiously accord to the household government of family patriarchs. These failed men, and accordingly the women and children in their families, needed to be subject to a new legal regime.

\section{SOCIOECONOMICS AND THE IDEAL OF DOMESTICITY IN THE NINETEENTH CENTURY}

Women's historians have long stressed the importance that ideas about the home and family assumed in the construction of gender relations in nineteenthcentury America. ${ }^{55}$ But the American ideology of domesticity, as it developed and became hegemonic over the course of the nineteenth century, was always profoundly intersectional, and as much about socioeconomics as about gender. The nineteenth century saw the rise of a powerful concept of domesticity that defined proper family life to revolve around a particular ordering of familymarket relations, in which the husband earned a salary regular and ample enough to support his entire family, the wife and children performed no market labor, and all family members resided within a comfortable home. This was an ideal in which economic relations, increasingly dominated by wage labor in the nineteenth century, played a remarkably large role. It was also a measure of successful family formation, and successful fatherhood more specifically, by which large numbers of Americans were predestined to fall short.

There was a real irony and a real unfairness embedded in the dominant nineteenth-century understanding of successful and failed fatherhood. The labor movement was agitating for a "family wage" so energetically in this period precisely because such an income was not available to most working men. ${ }^{56}$ Similarly, opposition to child labor became such a highly charged issue among middle-class reformers in the nineteenth century because so many families still

55. Barbara Welter's Cult of True Womanhood is the seminal examination of gender in the literature of domesticity. See Barbara Welter, The Cult of True Womanhood: 1820-1860, 18 AM. Q. 151 (1966). For other leading accounts of the vision of women in antebellum American writing on domesticity, see Mary P. Ryan, The Empire of the Mother: American Writing About Domesticity, 1830-1860 (1982); and Kathryn Kish Sklar, Catharine Beecher: A Study in American Domesticity (1976). Nancy Cott has valuably added to this literature by examining women's diaries and letters between 1780 and 1835 in order to consider "how a certain congeries of social attitudes that has been called the 'cult of true womanhood' and the 'cult of domesticity,' and first became conspicuous in the early nineteenth century, related to women's actual circumstances, experiences, and consciousness." NANCY F. CoTT, THE BondS of Womanhood: "Woman's Sphere" in New England, 1780-1835, at 1-3 (2d ed. 1997).

56. See 9 S. Doc. No. 61-645, at 14 (1910); Jeanne Boydston, Home and Work: Housework, Wages, and the Ideology of Labor in the Early Republic 99, 155 (1990); Alice Kessler-Harris, A Woman's Wage: Historical Meanings and Social Consequences 8-9 (1990); Amy Dru Stanley, From Bondage to Contract: Wage Labor, Marriage, and the Market in the Age of Slave Emancipation 165-66 (1998); Nancy Fraser \& Linda Gordon, A Genealogy of Dependency: Tracing a Keyword of the U.S. Welfare State, 19 Signs 309, 318-19 (1994); Martha May, Bread Before Roses: American Workingmen, Labor Unions and the Family Wage, in WOMEN, WORK AND PROTEST: A CENTURY OF US WOMEN's LABOR HISTORY 1, 3-10 (Ruth Milkman ed., 1985); infra text accompanying notes 76-79. 
depended upon their children's earnings stream for their survival. ${ }^{57}$ Familymarket orderings that the ideology of domesticity took to be a conclusive sign of a father's personal failure, the result of his moral depravity, weak character, and insufficient masculinity, actually had deeply structural roots. The standard of paternal success, as it came to be conventionally defined in the nineteenth century, required an arrangement of family and market life that was increasingly available to white middle-class Americans, but far less realizable by less privileged populations.

Nonetheless, the notion that successful fatherhood meant earning a wage sufficient to support one's entire family and keep it out of market labor gathered tremendous ideological potency throughout the nineteenth century. That definition of success, in turn, meant that vast numbers of family men were now culturally identified as failed fathers. This failure, moreover, combined with what many elites could understand as another one. A disproportionate share of the fathers unable to conform their market relations to the domestic ideal were not only poor, but also members of ethnically or racially disfavored populations, which made it significantly more difficult for them to claim the public's intrinsic respect as the heads of their own households. The combination of these two failures helped convince a growing population of reformers and lawmakers that the historical norms protecting a patriarch's government of his family should not apply to these fathers, whose entire families were now definitively classified as socially deviant. New ideas about childhood led the policy leaders and decision makers to focus in particular on the parent-child relationship in these failed families.

\section{Domesticity, and Failed Home Life, Defined}

To a striking extent, the nineteenth century's understanding of domesticity was transformed by the emergence of the wage labor economy. The vision of appropriate family life that came to dominate the nation's cultural consciousness as early as 1830 would have made little sense before the rise of that type of market relation. This ideology posited a separation between work and home, provider and provided for, of a sharpness not comprehensible in an agricultural economy before widespread industrialization. ${ }^{58}$ It characterized work as the exclusive domain of adult men, and celebrated the home as a complete and comfortable respite from labor that was populated by women and children whose husbands and fathers had protected them from the cruel demands of the market. ${ }^{59}$ As one typical author described family life, husbands and fathers

57. See infra text accompanying notes $62-69,83-85$.

58. Tellingly, similar ideologies of domesticity emerged and came to prominence in other industrializing nations in the early nineteenth century. See AnNa Clark, The Struggle for the Breeches: Gender and the Making of the British Working Class 197-271 (1995); Deborah Simonton, A History of European Women's Work, 1700 to the Present 87-96 (1998); John Tosh, A Man's Place: Masculinity and the Middle-Class Home in Victorian England 4-5 (1999).

59. In contrast, for example, Mary Ryan's study of Whitestown, New York found that "[b]etween 1790 and 1820 the household was the principal, almost solitary place of production within the 
spent their days in "the busy and turbulent world," leaving women and children free to dwell in the "sanctuary of rest" that men only returned to at night. ${ }^{60}$ Women and children, on this account, resided in "a refuge from the vexations and embarrassments of business." 61

Indeed, children sheltered from the market became perhaps the preeminent sign of a father's successful family formation in the nineteenth century, although one always tied to the twin need for a wife at home. Eighteenth-century Americans, still under the heavy influence of Calvinist principles, had generally accepted that children were born corrupt and needed to be brought to salvation through reason and deliberate choice when confronted with alternatives in the world. ${ }^{62}$ But over the course of the nineteenth century, that view was progressively replaced by the understanding that children were born innocent and highly vulnerable to worldly contamination. ${ }^{63}$ This faith in childhood innocence

township ... Parents conceived of their children as their own flesh, blood, and labor supply." MARY P. Ryan, Cradle of the Middle Class: The Family in Oneida County, New York, 1790-1865, at 25-26 (1981).

60. Mrs. A.J. Graves, Woman in America; Being an Examination into the Moral and Intellectual Condition of American Female Society 163-64 (New York, Harper \& Bros. 1847).

61. Charles Burroughs, an Address on Female Education, Delivered in Portsmouth, NewHAMPSHIRE, OCTOBER 26, 1827, at 18 (Portsmouth, Childs \& March 1827). E. Anthony Rotundo's research into the private letters of men and women in the nineteenth century has revealed many statements that echo the nineteenth-century prescriptive literature's account of appropriate domesticity, suggesting the pervasive power of this ideological vision. In one characteristic letter from 1868 , for instance, Mary Clarke reported to her suitor that she "'often [thought] it is so different for men from what it is with us women. Love is our life our reality, business yours."' E. ANTHONY Rotundo, american Manhood: Transformations in Masculinity from the Revolution to the Modern ERa 168 (1993) (quoting Letter from Mary Clarke to Willie Franklin (Sept. 10, 1868)). Alexander Rice would have agreed. He explained to his future wife in 1844 that a family's economic fate (and social status) rested on the efforts of the husband and father. He was the person " upon whose arm you are to lean thro' life, upon whose reputation your own will rest and upon whose effects your happiness as well as his own will mainly depend." Id. at 169 (quoting Letter from Alexander Hamilton Rice to Augusta McKim (Mar. 2, 1844)).

62. For evidence of the eighteenth-century conception that children were born without innocence to lose, see Nancy F. Cott, Eighteenth-Century Family and Social Life Revealed in Massachusetts Divorce Records, 10 J. Soc. Hist. 20, 29-30 (1976); and Peter Gregg Slater, Views of Children and of Child Rearing During the Early National Period: A Study in the New England Intellect 41-44 (1970) (unpublished Ph.D. dissertation, University of California (Berkeley)) (on file with author). Traces of this view remained in the early nineteenth century. See LEONARD Woods, LetTers to Unitarians Occasioned by the Sermon of the Reverend William E. Channing at the Ordination of the Rev. J. SPARKS 50-51 (Andover, Flagg \& Gould 1820) (“[C]hildren are prone to evil, inclined to go astray. Any plan of education, whether domestic or public, which should overlook this principle, and involve the opposite one of man's native purity, would be regarded by all men of sober experience and sober judgment, as romantic and dangerous.").

Philippe Ariès has tracked this understanding of childhood before and during the eighteenth century in Europe. He found, for instance, no assumption of childhood sexual innocence in early seventeenthcentury France. See Philippe Ariès, Centuries of Childhood: A Social History of Family Life 100 (Robert Baldick trans., Alfred A. Knopf 1962) (1960) ("The modern reader of [a] diary . . o of the young Louis XIII's life is astonished by the liberties which people took with children, by the coarseness of the jokes they made, and by the indecency of gestures made in public which shocked nobody and which were regarded as perfectly natural.").

63. For articulations of this new understanding of childhood, see Catharine E. Beecher, Religious Training of Children in the School, the Family, and the Church 157 (New York, Harper \& Bros. 
led many middle-class reformers to argue that corporal punishment was only appropriate as a last resort, ${ }^{64}$ on the ground that obedience could be better secured through appeals to a child's inherent sense of love and goodness. ${ }^{65}$ It gave still greater power to the mounting cultural and political opposition to child labor.

The legitimacy of child labor had been widely accepted in the eighteenth and early nineteenth centuries. By the middle of the nineteenth century, however, many middle-class Americans had begun to fervently reject the proposition that children should contribute to their family's income stream. ${ }^{66}$ The shift was linked to the spread of industrialization; child labor on a family farm aroused no opposition even in the nineteenth century, as Americans continued to believe that agricultural labor was good training for adult life and independent citizenship. ${ }^{67}$ But the rising opposition to child labor was also inextricably tied to ascendant ideas about the nature of childhood and parental, particularly paternal, responsibility. For the growing number of opponents to child labor, this mode of family-market organization came to represent the corruption of childhood innocence and conclusive evidence of a father's deliberate indifference and willful exploitation. Harper's Magazine offered a standard characterization

1864) ("[T]his doctrine of transmitted infant depravity ... . has been the [cause of the] CONFLICT of AGES, in which common sense has been struggling against this theological dogma and the systems resulting from it."); Horace Bushnell, Christian Nurture 10 (New York, Charles Scribner 1861) ("[T]he aim, effort, and expectation should be, not, as is commonly assumed, that the child is to grow up in sin, to be converted after he comes to a mature age; but that he is . . to have loved what is good from his earliest years."); and infra text accompanying notes 70-71.

64. Elizabeth Pleck has calculated that six out of the seven child rearing manuals published in England or America in the last half of the nineteenth century advised parents to limit their use of corporal punishment. See PLECK, supra note 49, at 34. For examples from the child rearing literature calling for a greater reliance on non-corporal techniques of control, see MARY BLAKE, TwENTY-SIX Hours A DaY 110-11 (Boston, D. Lothrop \& Co. 1883) ("There will be times, and I say it in all sadness, when nothing will answer but the rod .... It should always be the last resort, and never, never, NEVER when the parent is angry. Stop and think about it, be sure you are right and just and calm."); and Lyman Cobb, The Evil Tendencies of Corporal Punishment as a Means of Moral Discipline in Families and Schools, Examined and Discussed 9 (New York, Mark H. Newman \& Co. 1847) ("As long as the conduct of the parent or teacher is influenced solely by an affectionate and conscientious desire to benefit the child, he has the right to punish; but, beyond that he has no right whatever .....").

For a discussion of the rise of opposition to corporal punishment in other contexts, see MYRA C. Glenn, Campaigns against Corporal Punishment: Prisoners, Sailors, Women, and Children in Antebellum America (1984); and James Turner, Reckoning with the Beast: Animals, Pain, and Humanity in the Victorian Mind (1980).

65. As Humphrey explained, a child would respond to love-based appeals more strongly and more quickly than he would respond to reason. A child might be "too young, indeed, to know why it yields," but he would not be "too young to feel the power by which its heart is so sweetly captivated." H. Humphrey, Domestic EduCATION 184 (Amherst, J.S.\&C. Adams 1840); see also infra text accompanying notes 72-73.

66. For an excellent account of this transition, see Viviana A. Zelizer, Pricing the Priceless Child: The Changing Social Value of Children 56-72 (1985).

67. See id. at 77; see also 41 Cong. REC. 1552 (1907) (statement of Sen. Beveridge) ("This bill does not strike at the employment of children engaged in agriculture. I do not for a moment pretend that working children on the farm is bad for them. I think it is the universal experience that where children are employed within their strength and in the open air there can be no better training."). 
of the practice in 1873, reporting that children performed market work simply because their fathers were "indifferent" to their "natural growth and improvement" and lacked the "disinterestedness" needed "to be able to forego present profit for the future benefit of the little one." ${ }^{68}$ Fathers whose children labored in the market had, the New York Times editorialized in more dramatic terms, "no civilization, no decency, no anything but covetousness." 69

If a father's success was beginning to turn sharply in the nineteenth century on whether his children labored in the market, the growing opposition to child labor was also firmly linked to the understanding that successful family life, and successful fatherhood, depended on keeping wives and mothers at home and focused on domesticity. The child rearing literature of the nineteenth century operated on the presumption that healthy child development required not only the banishment of child labor, but also a mother's constant presence and ceaseless vigilance against the appearance of sin. Mrs. Child explained that "[t]he rule ... for developing good affections in a child is, that he never be allowed to see or feel the influence of bad passions, even in the most trifling things."70 "While the character of the babe is forming," Mrs. L.H. Sigourney similarly advised, mothers needed to "let every action and indication of motive, be a subject of observation."71

The turn from corporal punishment, moreover, only intensified the cultural requirement that a mother's time and energy be devoted exclusively to her home and children. The literature advocating restraint in physical chastisement advised mothers to rely instead on far more time-intensive techniques of moral suasion and affective manipulation. These new strategies of securing obedience depended on the development and indefatigable maintenance of intense, almost romantic bonds between mother and child, such that a mother's mere threat to withdraw some of her love and attention would be sufficient to secure a child's prompt and eager obedience. ${ }^{72}$ As Lyman Cobb summarized the strategy in a

68. The Little Laborers of New York City, 279 HARPER's New Monthly MAG. 321, 321 (1873).

69. Child Labor in Coal Mines, N.Y. TIMEs, Dec. 17, 1902, at 8. More rigorous compulsory schooling laws, reflecting similar societal impulses, also appear to have helped the movement against child labor, although perhaps it was the other way around. Paul Osterman argues, for instance, that compulsory schooling laws were enacted and enforced precisely when the extent of child labor had already diminished. As he explains, "[s]ince firms no longer required the labor of children and adolescents, those pressing for longer compulsory schooling were able to succeed." PAUL OSTERMAN, Getting Started: The Youth Labor Market 60-61 (1980); see also Forest Chester Ensign, CompulSORY School Attendance AND ChILd Labor 236 (1921) ("That child labor and compulsory school attendance represent but two aspects of a single problem is now generally recognized .... [T]he laws themselves are usually worked out with such care as to insure reasonable harmony ...."); MIRIAM E. Loughran, The Historical Development of Child-Labor Legislation in the United States 5 (1921) (" $[I] t$ is recognized that the enforcement of the child-labor law is practically impossible without the assistance of a school attendance law which keeps the child in school during the time when he is not legally permitted to work.").

70. Mrs. Child, The Mother's Book 9 (Boston, Carter \& Hendee 2d ed. 1831).

71. Mrs. L.H. Sigourney, Letters to Mothers 81 (Hartford, Hudson \& Skinner 1838).

72. Richard Brodhead has very aptly termed this approach to child rearing "discipline through love." Richard H. Brodhead, Cultures of Letters: Scenes of Reading and Writing in Nineteenth-Century AMERICA 18 (1993). 
tract also concerned with order in the classroom, "[t]he parent or teacher should, first of all, secure the LOVE and affection of his children or pupils. He will then have an unlimited control over their minds and conduct."73

The nineteenth-century literature on appropriate family life recognized that its methods placed significant demands on parents. But it reasoned that mothers who failed to constantly supervise their children at home, and fathers who failed to make that possible, had to lack love and concern for their children. As one commentator reported, these parents did "not consider the welfare and happiness of their children in future life, and their own happiness in connection with them as they advance towards their declining years, as of sufficient importance to call for the bestowment of this time and attention." 74

\section{The Socioeconomics of Failed Fatherhood}

This vision of home and family was deeply gendered. It prescribed starkly differentiated roles for men and women, refused to count women's household labor as a form of work, ${ }^{75}$ and evaluated women (and children) according to judgments about the adult men who led or were supposed to lead their families. But it also had a sharp class content. The dominant nineteenth-century account of successful domesticity and successful fatherhood assumed, endorsed, and demanded an ordering of family-market relations that was becoming more common among the white middle class, but remained literally impossible for many Americans to achieve.

Most notably, large numbers of husbands and fathers were simply unable to earn enough to support their families on their own, even in relatively good economic times. ${ }^{76}$ Indeed, wage dependents in the nineteenth century were frequently paid at or below the subsistence level and experienced chronic unemployment. ${ }^{77}$ In the relatively prosperous year of 1890 , for instance, $19 \%$ of the male labor force in Massachusetts found itself unemployed at some point, and these men remained out of work for an average of 3.3 months. ${ }^{78}$ The outlook was even bleaker, moreover, during one of the economic downturns that regularly cycled through the nineteenth-century economy. No less than $29.6 \%$ of the male Massachusetts labor force was out of work at some point during the

73. СоBB, supra note 64 , at 104.

74. Jacob Abbott, Gentle Measures in the Management and Training of the Young 292 (New York, Harper \& Bros. 1871).

75. For an extended discussion of nineteenth-century accounts of housework that refused to recognize it as a form of labor, see BoYdSTon, supra note 56, at 142-63.

76. See supra note 56 and accompanying text.

77. See Alexander Keyssar, Out of Work: The First Century of Unemployment in MassachuSETTS 45 (1986) ("[M]ost workingmen [in nineteenth-century Massachusetts] did little more than keep themselves afloat, and many were not paid enough to support a family at all."); STANLEY, supra note 56, at 101 ("[W]age work [in the postbellum nineteenth century] left both skilled and unskilled vulnerable to casual labor, pay below subsistence levels, and unemployment - each an expression of the fluctuating rhythms of commodity production.").

78. See KeYSSAR, supra note 77, at 47, 50, 51 tbl.3.2, 58. 
depression year of 1885 , and the average period of unemployment lasted 4.2 months. ${ }^{79}$

For this reason, many families were vitally dependent on the economic contributions of wives and children. While the overall number of married women who worked outside the home in the nineteenth century was small, ${ }^{80}$ many wives needed to add to their household's income stream. Outside work was most frequent among wives who were African-American, foreign-born, or in the native white working class. ${ }^{81}$ In addition, the same groups of wives more typically earned money while in their homes, most often by taking in piecework, laundry, or boarders. ${ }^{82}$

79. See id. at $47,50,51$ tbl.3.2.

80. The 1890 census, for instance, found that only $4.6 \%$ of all married women were "engaged in gainful occupations." Bureau of the Census, Dep't of Commerce and Labor, Statistics of Women at Work Based on UnPublished INformation Derived from the Schedules of the Twelfth Census: 1900 , at 9,22 tbl.16 (1907). This statistic included a mere $2.2 \%$ of native-born white wives with two native-born parents who were gainfully employed. See id. at 22 tbl.16. The figure was $2.7 \%$ for native-born white wives with at least one foreign-born parent, $3.0 \%$ for foreign-born white wives, 22.7\% for African-American wives, and $8.6 \%$ for "Indian and Mongolian" wives. Id.

81. See, e.g., Paula Giddings, When and Where I EnTer: The Impact of Black Women on Race AND SEX IN AMERICA 48 (1984) ("By 1847 a census revealed that close to half the female Black population of Philadelphia consisted of washerwomen and domestic servants .... While the White female labor force was made up primarily of single women, Black women, both married and single, were forced to

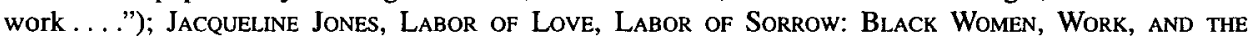
Family from Slavery to the Present 63 (1985) ("[I]n 1870 more than four out of ten black married women listed jobs, almost all as field laborers. By contrast, fully 98.4 percent of white wives told the census taker they were 'keeping house' and had no gainful occupation."); Alice KeSsLer-Harris, OUt to Work: A History of Wage-Earning Women IN THE UNITEd States 121 (1982) ("[F]amilies of unskilled workers frequently found it impossible to live on the income of a single wage-earner .... Tenement rents [in Lawrence, Massachusetts] in 1893, when wages dipped below the $\$ 300$ mark, were often $\$ 200$ a year. By this time a man had difficulty surviving unless his children as well as his wife worked."); Claudia Goldin, Family Strategies and the Family Economy in the Late Nineteenth Century: The Role of Secondary Workers, in PhiladelPhia: Work, SPACE, FamlLy, and GROUP EXPERIENCE IN THE NineteEnTH Century 277, 280-81 (Theodore Hershberg ed., 1981) [hereinafter Goldin, Family Strategies] (reporting, based on 1880 U.S. Federal Population Census manuscripts for Philadelphia, that over twenty percent of all black married women "worked for pay on a full-time basis"); Claudia Goldin, Female Labor Force Participation: The Origin of Black and White Differences, 1870 and 1880, $37 \mathrm{~J}$. ECON. HIST. 87, 91, 94 (1977) (reporting, based on U.S. Population Census manuscripts from seven southern cities for 1870 and 1880 , that "[b]lack women participated in the labor force on average three times more than did white women, and married black women averaged almost six times the rate of married white females"); source cited supra note 80.

82. See BoYDSTON, supra note 56, at 89 (describing poor married women-immigrant and nativeborn, white and black - who "concentrated on strategies of selling their domestic labor within their own homes-working at home as outwork needlewomen, for example" or taking in boarders or laundry); James Oliver Horton \& Lois E. Horton, Black Bostonians: Family Life and CommuntTy StrugGle IN THE ANTEBELluM NORTH 16-18 (1979) (reporting that antebellum free black wives frequently took in boarders, a practice that was an important source of income for them); Christine Stansell, City of Women: SeX and Class in New YoRK, 1789-1860, at 106-19 (1986) (describing poor women's piecework in the New York garment industry); Thomas Dublin, Women and Outwork in a NineteenthCentury New England Town, in The Countryside in the Age of CaptTalist Transformation: Essays in the Social History of Rural America 51, 52-54, 60-62, 64 (Steven Hahn \& Jonathan Prude eds., 1985) (discussing the piecework of poor rural wives); Sharon Harley, Northern Black Female Workers: Jacksonian Era, in The Afro-American Woman: Struggles and Images 5, 10 (Sharon Harley \& 
Many poor and working-class families in the nineteenth century, immigrant and native-born, also found that their children's earnings were absolutely indispensable to their economic survival, no matter what middle-class reformers thought about the practice of child labor and imagined about the motivations behind it. One study of white families in Philadelphia in 1880, for example, discovered that the children of Irish-born men earned between thirty-eight and forty-six percent of their households' total income, while their peers with German-born fathers earned between thirty-three and thirty-five percent, and the children of native-born fathers earned between twenty-eight and thirty-two percent. $^{83}$ As a consequence of this sort of dependency, market labor was probably even more common among children than among wives in the nineteenth century. The 1870 census, employing a definition that excluded many child workers, still counted 765,000 children between the ages of ten and fifteen who were gainfully employed, representing almost six percent of the total work force. ${ }^{84}$ Thirty years later, the 1900 census recorded 1,750,000 child workers, almost one million more than reported in 1870 and now slightly over six percent of the working population. ${ }^{85}$

In representing both work and home life, the nineteenth-century ideology of domesticity frequently claimed to be just depicting the world as it was. But it was not doing that. The ideology of domesticity was normatively invested in a specific mode of family-market relations. Its vision of work and home was an idealized, prescriptive account, in which cultural norms about sex and economics infused the way in which the world was being portrayed. By purporting to

Rosalyn Terborg-Penn eds., 1978) (reporting that black married women frequently earned money at home as laundresses or seamstresses).

83. See Goldin, Family Strategies, supra note 81, at 284; see also Michael R. Haines, Poverty, Economic Stress, and the Family in a Late Nineteenth-Century American City: Whites in Philadelphia, 1880 , in PHILAdelPHIA, supra note 81, at 240, 265 ("The finding that poorer families sent their children to work is certainly not a startling one. But the fact that it appears to have been the main source of additional support for late nineteenth-century urban families under economic stress is not obvious."); John Modell, Changing Risks, Changing Adaptations: American Families in the Nineteenth and Twentieth Centuries, in Kin AND CommuntTIEs: FAMILIES IN AMERICA 119, 128 (Allan J. Lichtman \& Joan R. Challinor eds., 1979) (describing child labor in working-class families "as an attempt to pool risks in what was experienced as a very uncertain world").

84. See 1 Bureau of the Census, U.S. Dep't of Commerce, Historical Statistics of the United States: Colonial Times ro 1970, at 134 ser.D 75-84 (1975) (reporting 765,000 child workers out of a total work force of $12,925,000)$. The Census Bureau's definition of gainful worker excluded many children performing market labor:

Census enumerators were instructed to find and enter the occupation of each person 10 years of age and over who followed an occupation in which he earned money or its equivalent, or in which he assisted in the production of marketable goods. Thus, the term "gainful workers" includes all persons who usually followed a gainful occupation although they may not have been employed when the census was taken. It does not include women doing housework in their own homes, without wages, and having no other employment, nor children working at home, merely on general household work, or chores, or at odd times on other work.

Id. at 124.

85. See id. at 134 ser.D 75-84 (reporting 1,750,000 gainfully employed workers between the ages of ten and fifteen out of a total work force of 29,073,000). 
simply describe the world as it was, however, this body of thought was able to characterize families without the preferred family-market ordering as deviant, abnormal, and personally at fault. Its definition of successful fatherhood-of normal fatherhood, really-immediately created a large population of failed fathers, blamed for the fact that they did not earn enough to support an entire family, and of failed families, whose status was inextricably tied to their unsatisfactory patriarch.

To make matters worse, the concept of failed fatherhood drew power from racial divides, as well as those of class and gender. These failed fathers disproportionately carried an ethnic or racial identification that made it much more difficult for them to command the state's intrinsic respect for their household governance. The almost five million immigrants who arrived in the United States between 1830 and $1860,{ }^{86}$ and the over ten million who came during the next thirty years, ${ }^{87}$ quickly suffered more than their share of lowwage employment, chronic unemployment, and poverty. ${ }^{88}$ Native-born Americans frequently understood these immigrants, who were overwhelmingly from Europe ${ }^{89}$ to be fundamentally different and unchangeably inferior, not just culturally, but ethnically and even racially as well. America's racial taxonomies were in flux during the nineteenth and early twentieth centuries, especially in the North where the African-American population was much smaller. ${ }^{90}$ Throughout this period, southern states focused intently on the white-black dichotomy that came to dominate modern American thought. ${ }^{91}$ Northerners, however, were

86. See id. at 106 ser.C 89-119.

87. See id.

88. See, e.g., Michael B. Katz, Poverty and Policy in American History 12 (1983); Keyssar, supra note 77, at 79-88; Priscilla Ferguson Clement, The Transformation of the Wandering Poor in Nineteenth-Century Philadelphia, in Walking to Work: Tramps IN AMERICA, 1790-1935, at 56, 65-67 (Eric H. Monkkonen ed., 1984).

89. See 1 Bureau of THE Census, supra note 84 , at 106 ser.C 89-119.

90. The census reported 125,000 African-Americans in the Northeast in 1830, 156,000 in 1860, and 385,000 in 1900 . The African-American population in the South was vastly larger: 2,162,000 people in $1830,4,097,000$ in 1860 , and 7,923,000 in 1900. See id. at 22 ser.A 172-194.

91. Legal definitions of race in the nineteenth-century South consistently turned on the divide between white and black. Antebellum North Carolina, for instance, recognized no racial distinctions between white people, but provided that "[a]ll free persons descended from negro ancestors, to the fourth generation inclusive, though one ancestor of each generation may have been a white person, shall be deemed free negroes and persons of mixed blood." N.C. Rev. CODE ch. 107, § 79 (1855); see also State v. Chavers, 50 N.C. (5 Jones) 25, 27-28 (1857) (enforcing provision). Virginia's 1849 code similarly enforced a strict white-black dichotomy, excluding from whiteness "[e]very person who has one-fourth part or more of negro blood." VA. CODE ch. 103, § 3 (1849). After the Civil War, Tennessee enacted a statute providing "[ $[$ ] African blood in their veins, shall be known in this State as 'Persons of Color." An Act to define the term "Persons of Color," and to declare the rights of such persons, ch. $40, \S 1,1866$ Tenn. Pub. Acts 65 , 65; see also An Act Preliminary to the Legislation Induced by the Emancipation of Slaves, § 3, 1865 S.C. Acts 10, 10 (providing that "[a]ll free negroes, mulattoes and mestizoes, all freedmen and freedwomen, and all descendants through either sex of any of these persons, shall be known as persons of color, except that every such descendant, who may have of Caucasian blood seven-eighths or more, shall be deemed a white person"). In 1896, the Supreme Court found that the Reconstruction 
much more likely to see racial divisions between people now understood to be white and to locate racial inferiority in these groups. When the United States Immigration Commission compiled a Dictionary of Races or Peoples in 1911, for instance, it officially identified forty-five different races among the immigrants to the United States. ${ }^{92}$ Thirty-six of these races were indigenous to Europe ${ }^{93}$ including such races as Germans, Hebrews, Irish, Italians, and Poles. ${ }^{94}$

In the standard nineteenth-century view, the racial inferiority of these immigrants was particularly likely to manifest itself as a profound and permanent unfitness for self-government, in both its public and private forms. ${ }^{95}$ Some native-born critics focused on the immigrant's supposedly inborn incapacity for self-government in the political arena. James Russell Lowell, for instance, offered typical warnings in 1884 , predicting that American democracy was threatened because "the most ignorant and vicious of a population ... has come to us from abroad, wholly unpracticed in self-government and incapable of assimilation by American habits and methods." policymakers described immigrants' failures within their own households in parallel terms. Francis Walker, for example, explained in 1896 that the immigrants who crowded nineteenth-century America's cities were "beaten men from beaten races," who had "none of the ideas and aptitudes which fit men to take up readily and easily the problem of self-care and self-government." Massachusetts Board of State Charities elaborated on this latter theme, reporting that racial inferiority, "inherited organic imperfection,-vitiated constitu-

Amendments left these statutory definitions of race undisturbed. As the Court explained in Plessy $v$. Ferguson, 163 U.S. 537 (1896), "the proportion of colored blood necessary to constitute a colored person, as distinguished from a white person" was "to be determined under the laws of each State," id. at 552 .

92. See S. Doc. No. 61-662, at 2 (1911).

93. See id.

94. See id. at $64-68,73-75,79-85,104-06$.

95. For more detailed elaborations of this line of thought, see MatThew Frye Jacobson, Whiteness of a Different Color: European Immigrants and the Alchemy of Race 7-8, $48-49$ (1998); and Dale T. Knobel, PAdDy and the RePublic: Ethnicity and Nattonality in ANTEBellum America 54-57, 80-81 (1986). This contention was somewhat ironic, given the nature of the arguments against woman suffrage that were put forth in the same era. Opponents of woman suffrage in the late nineteenth and early twentieth centuries frequently asserted that a federal constitutional amendment guaranteeing women the vote would unreasonably interfere with "local self-government" in two senses. First, it would deprive men of the ability to determine the qualifications for suffrage on a state-by-state basis. Second, it would threaten the self-government of families, by which the opponents of woman suffrage meant that the proposed amendment would strip men of sovereign control over their wives. See Reva B Siegel, She, the People: The Nineteenth Amendment, Sex Equality, Federalism, and the Family, 115 HARv. L. REv. (forthcoming Feb. 2002) (manuscript at 45-54, on file with author). These anti-suffrage arguments were grounded in the premise that men were always fit for self-government in both politics and family life, at the same time that Americans in other contexts were arguing with equal vigor that foreign-born men precisely lacked that capacity.

96. James Russell Lowell, Democracy (1884), in Essays, Poems and Letters 143, 147 (William Smith Clark II ed., 1948).

97. Francis A. Walker, Restriction of Immigration, 77 AtLantic MonThLy 822, 828 (1896) (emphasis added). 
tion,- - or poor stock," primarily explained the inability of poor men to adequately support their families. ${ }^{98}$ The widespread incidence of failed fatherhood was troubling enough, but the fact that many of these men were (understood to be) racially predisposed to such failure could only be considered a stronger sign that the preconditions for recognition as a patriarch were not being met. The combined situation helped convince leading reformers and lawmakers that the common law's fierce deference to patriarchal household government should not apply to these husbands and fathers. These men-and, it was thought to naturally follow, the women and children in their families-required a new and different governing scheme.

\section{DOMESTIC INTERVENTION}

Part II examines the legal regimes that were created beginning in the nineteenth century to regulate failed fathers and the women and children whose status turned on this evaluation of the men who headed or were supposed to head their households. These regimes were highly suspicious of parental judgment, committed to the intense scrutiny of family life, and eager to remake familial relations. Drawing on the growing elite consensus described in Part I, they operated on the premise that common law rules and norms, which continued to govern economically successful families, were wholly inappropriate in the absence of a viable patriarch. The record of the rise of these new legal structures is, in part, a story about the emergence of the modern welfare state. But it is also, and more specifically, a uniquely legal history about the development of new bodies of law that regulated family life, yet took their logic from standing outside of what was conventionally and authoritatively known as family law. To analyze the emergence of this two-part regime for governing the legal treatment of parenthood, this Part focuses in particular on two crucial moments in the law's bifurcation.

In nineteenth-century reform movements, elite private philanthropy and state power frequently associated on intimate terms. As early as the $1850 \mathrm{~s}$ and $1860 \mathrm{~s}$, leading American reformers had become very interested in limiting the control that both fathers and mothers exercised over their children, in circumstances where those children did not have a father able to provide for his family's entire maintenance. With the founding of the Societies for the Prevention of Cruelty to Children, the first pivotal moment that this Part considers, that elite philanthropic impulse began to acquire tremendous legal support. The cruelty societies, like their more fully private predecessors, were disrespectful of both paternal and maternal autonomy and extremely anxious to intervene when families without an acknowledged patriarch were at issue. But the cruelty societies, established in New York City in 1874 and then rapidly spread

98. Second Annual Report of the Board of State Charties, at xxii (Boston, Wright \& Potter 1866). 
throughout the nation, quickly amassed and enthusiastically exercised unprecedented legal authority to investigate these families, arrest these parents, and remove these children.

By the early twentieth century, this bifurcation in the law's regulation of parenthood had begun to take what would become its more modern form. The second key moment that this Part examines concerns the mothers' pension laws that swept through state legislatures beginning in 1911. The mothers' pension programs had some new structural features that would also come to characterize successor regimes later in the twentieth and twenty-first centuries. They were entirely state-run. More importantly, they relied primarily on the provision and denial of crucial financial support, rather than the threat of separating families, to achieve their aims. But the underlying norms survived intact from the nineteenth century. Like the cruelty societies, the mothers' pension programs operated on the guiding presumption-always viscerally understood if never completely acknowledged-that parent-child relations in families without a viable patriarch needed to be scrutinized, regulated, and constantly reshaped, even though wholly different, and much less interventionist and instrumental, rules and norms continued to be appropriate for more economically successful families. Over the course of the nineteenth and early twentieth centuries, a two-part regime for governing parental relations had emerged and institutionalized itself, in a manner that is still with us today.

\section{A. PHILANTHROPIC INTERVENTION BETWEEN THE POOR AND THEIR CHILDREN}

By the mid-nineteenth century, a number of elite reform efforts had been founded on the principle that it was misguided, and even dangerous, to defer to the judgment and decision making of either parent in families without a father able to provide for his wife and children's entire support. The premise was starkly at odds with the basic norms that drove the common law's treatment of the family. But these reformers were increasingly sure that the deference to patriarchal household government that the common law so strongly endorsed was inappropriate for failed fathers and the women and children associated with them, although still well-suited to the households of more economically successful family men. While the reformers were not initially imbued with any particular legal powers, they energetically worked within the confines of existing law to limit parental authority in their targeted families. By the 1870 s, the similar reform commitments advanced by the Societies for the Prevention of Cruelty to Children would lead to the creation of new bodies of law.

The first signs of this reform agenda were visible at least as early as the 1830 s, in the Sunday school movement directed at poor urban children. By later standards, the Sunday schools' intervention into families was extremely mild: The schools simply offered religious education to children. But the schools explicitly sought to displace parents (especially mothers) as the primary moral instructors of their children, in an era that generally revered a mother's personal- 
ized and privatized instruction. ${ }^{99}$ The movement's leaders grounded their deviation from the traditional celebration of parental guidance on the conviction that the lessons their students received at home had no value and in fact needed to be diligently counteracted. As the Reverend John Todd phrased the notion, the schools believed they were the antidote to "the poison of wrong example and wrong teaching at home." 100 The only real evidence that the Sunday school leaders had to support this evaluation of their students' parents, which applied at least as much to their mothers as to their fathers, was the simple fact that these children came from families without a father able to support his dependents. In the vision of the Sunday school leaders, poor children who lived in "squalor"101 were necessarily being raised in "abodes of moral death"102 or "moral orphanage," 103 where they had no parents worthy of public respect or deference.

The energy and commitment that elite private reformers devoted to constraining parental authority and remaking parent-child relations in families without a recognized patriarch blossomed in the 1850s and 1860s. The Children's Aid Society of New York, founded in 1853 by Charles Loring Brace, ${ }^{104}$ represented the most striking manifestation.

The Children's Aid Society dedicated itself to removing poor children from New York City and placing them with farm families in the West. ${ }^{105}$ Between 1853 and 1890, the year of Brace's death, the society succeeded in relocating over ninety-two thousand people, almost all of them children. ${ }^{106}$ Although many of these children were orphans, approximately as large a group had at least one parent living. Four hundred $(51.5 \%)$ of the children placed out between February 1859 and February 1860, for example, fell into this latter category, as compared to 328 full orphans and 48 unknowns. ${ }^{107}$ All of the removed children were "“destitute,", 108 and a substantial minority was also foreign-born. In the 1859-1860 year, for instance, 296 (36.4\%) of the 814

99. See supra text accompanying notes 70-74.

100. John Todd, The Sabbath School Teacher: Designed to Aid in Elevating and Perfecting the SabBath School. System 262 (Northampton, J.H. Butler 1837).

101. The XXVth Annual Report of the American Sunday-School Union 21 (Philadelphia, The American Sunday-School Union 1849).

102. President Humphrey's Annual Sermon; or Thoughts on the Practicability of Universal Religious Education, and the Peculiar Adaptation of the Sunday School System to Effect It, Q. SUNDAY SCH. MAG., Oct. 1831, at 181, 189.

103. Id.

104. See Charles loring Brace, The Dangerous Classes of New York, and Twenty Years' Work AMONG THEM 84-88 (New York, Wynkoop \& Hallenbeck 1872).

105. See, e.g., id. at 92 (quoting first circular of the Children's Aid Society (Mar. 1853)).

106. According to the society's calculations, it relocated a total of 92,292 people between 1853 and 1890. See Thirty-Eighth Annual Report of the Children's Aid Society 17 (New York, Wynkoop, Hallenbeck \& Co. 1890). Adults accounted for only a small fraction of this number. In 1890, for instance, the society relocated 2851 people, only $286(10.0 \%)$ of them adults. See id. at 16 . On Brace's death, see id. at $\mathrm{v}-\mathrm{xx}$.

107. See Seventh Annual. Report of the Children's Aid Society 9 (New York, Wynkoop, Hallenbeck \& Thomas 1860).

108. BRACE, supra note 104, at 90 (quoting first circular of the Children's Aid Society (Mar. 1853)). 
transported people were foreign-born (mainly Irish and German), ${ }^{109}$ as compared to $456(56.0 \%)$ listed as "American," $3(.37 \%)$ classified as "Colored," and $59(7.2 \%)$ unknown. ${ }^{110}$

The Children's Aid Society had no special authority to separate parents from their children, but it seems to have taken advantage of every opportunity that the law did (at least arguably) make available. The society formally required permission from parents before it placed out their children because it could not have legally removed these children without such authorization. ${ }^{111}$ But the society was, in practice, apparently somewhat casual about parental notification and consent. The society felt comfortable referring to children with living parents as "orphans," and it hoped for their adoption by the families they lived with in the West. ${ }^{112}$ Parents routinely came forward to report that the society had not made clear the permanence of the separation intended. ${ }^{113}$ If a child apprised of the possibilities of western adventure responded by presenting himself as a (real) orphan, moreover, the evidence suggests that the society would frequently take the child with no questions asked or investigation made. ${ }^{114}$

109. Out of the 296 foreign-born people transported in 1859-1860, 177 were Irish, 95 were German, 14 were English, 7 were Scotch, and 3 were French. See Seventh ANNual Report of The Children's AID SocIETY, supra note 107 , at 9.

110. Id. The 814 total includes 38 adults. See id. Unfortunately, the society's statistics on national origin do not distinguish between children and adults, a distinction made in the statistics on parentage. See supra text accompanying note 107.

111. See BRACE, supra note 104 , at 235 (noting that these children "could not easily, on any legal grounds, be inclosed within Asylums"); Nash v. Douglass, 12 Abb. Pr. (n.s.) 187, 189 (Brooklyn City Ct. 1872) (reporting that children coming to the Children's Aid Society of Brooklyn "are examined by the agents of the society, and, if found to have parents or relatives, are required to procure their consent to the removal").

112. See Twei fTh ANnual Report of THE ChIm dren's Aid Society 42 (New York, Wynkoop \& Hallenbeck 1865) ("Observe one of these poor boys, taken from ... parents whose vices and crimes breed a comuption absolutely contagious. Follow him to his new Western home.... Perhaps he is adopted (not an unusual case) as the child of those, he only expected to serve as an orphan." (emphasis added)).

113. See BraCE, supra note 104, at 234-35.

114. For instance, the Children's Aid Society sent its first party of children west (to Michigan) in 1854. The Reverend E.P. Smith, who escorted the children on their journey, reported that some of the children were added at the very last minute, solely on their own statement that they were orphans. See The Life of Charles Loring Brace Chiefly Told in His Own Letters app. B at 492 (Emma Brace ed., New York, Charles Scribner's Sons 1894). Elbridge Gerry, later to become the driving force behind the New York Society for the Prevention of Cruelty to Children, found one child on the street " a few hours before" the group's departure and brought him to the Children's Aid Society. Id. at 493 (quoting the Company Book). The society sent the child to Michigan with the rest, after the boy reported that he was an orphan "with a quiet, sad reserve, that made us believe him truthful." Id. at 494 (quoting the Company Book). When the group stopped to transfer trains in Albany, the children made friends with another boy hanging around the tracks and convinced Smith to add him to the party, on the boy's assertion that he was an orphan as well. See id. at 495-96.

Later litigation suggests that the Children's Aid Society was slow to change its practices over time. Consider Nash v. Douglass, 12 Abb. Pr. (n.s.) at 187, in which Thomas Nash sued R.D. Douglass, an officer of the Children's Aid Society of Brooklyn, for enticing Nash's son William away, see id. at 188 . William, eighteen and apparently eager to go west, had told Douglass that he was an orphan named William Smith, born in Flushing, Queens. Douglass conceded that he had accepted this story without undertaking any independent investigation in Flushing. William had been sent to a farm in Missouri and 
The entire operation ran on the premise that virtually any level of intrusion, control, and manipulation was appropriate to counteract the authority that these parents exercised over their children. The Children's Aid Society explained its overriding conviction in terms that were becoming quite typical. As an initial matter, the society stressed that "an immense proportion"115 of the parents involved were foreign-born-"miserable creatures of Europe, the scum and refuse of ill-formed civilizations"116 - and racially predisposed to failed household government. ${ }^{117}$ As it turned out, the families the society separated actually included more native-born Americans than the society generally liked to acknowledge. ${ }^{118}$ But it was definitely the case that none of these families contained a father able to support his wife and children adequately, and the society emphasized this fact most of all. When the society reported that its removal program was desperately needed to save children from their "vile parents," 119 its evidence of vileness was precisely that these children were not protected from the demands of the market and instead frequently labored within it. On the society's account, this deviation from ideal domesticity was unquestionably deliberate. It reflected the same deep-seated moral and character flaws, the same "vices and crimes," that explained the persistence of the family's poverty in the first place. ${ }^{120}$ Only woefully inadequate parents-uncaring, immoral, and indolentkept their children "in the street to earn something for their support."121

This standard of parental fitness contained more than the usual ironies where the Children's Aid Society was concerned. Not only was it blind to the structural constraints of poverty, it also ignored the society's own promotion of child labor. The most important way that the society induced western families to receive the children that the society had removed was by promising them that the children would work for their keep. Their new homes were not much of a

had soon left it to set out on his own. See id. at 188-90. The Brooklyn City Court held that Douglass had not acted wrongfully, however, reasoning that "[i]f the first hundred men met with in [Flushing] had never seen William Smith, if the postmaster, sheriff, commissioners of the poor, had never heard of him, that would not have been inconsistent with his truthfulness." Id. at 191. As the court explained, " $[\mathrm{t}]$ he poor and unprotected, not noticeable for improper or criminal conduct, are generally little known, and if known, are soon forgotten." Id.

115. BRACE, supra note 104 , at 35 .

116. Third Annual Report of the Children's Aid Society 4 (New York, M.B. Wynkoop 1856).

117. See supra text accompanying notes $95-98$.

118. See supra text accompanying notes 109-10.

119. Second Annual Report of the Children's Aid Society 5 (New York, M.B. Wynkoop 1855).

120. Twelfth ANnual Report of the Childoren's Aid Society, supra note 112, at 42 ("Observe one of these poor boys, taken from his birthright of squalid want and haggard misery-from parents whose vices and crimes breed a corruption absolutely contagious.... [In the West,] [h] e finds a pure air, bountiful meals, comfortable clothing, and, for the first time in his life, a home."); see also SECOND ANNuAl RePORT OF THE ChILdRen's AID Society, supra note 119, at 5 (noting "that no relief can be of permanent value to society, or to the poor themselves, without influence in some form, on character"); ThiRd ANNuAl RePort of THE ChILDREN's Aid Society, supra note 116, at 27 ("In nine cases of ten, it is probable, some cursed vice has thus reduced her [an impoverished woman whose children a society agent found gathering coal in the street], and that, if her children be not separated from her, she will drag them down, too.").

121. Brace, supra note 104, at 42 . 
refuge from labor after all. ${ }^{122}$ But the Children's Aid Society applied its standards of parental success and failed fatherhood without qualm, nonetheless, convinced that the parents it dealt with did not meet the preconditions for deference or respect. By the mid-1870s, this sort of elite philanthropic conviction began to have a major legal impact, spurring the creation of new bodies of law governed by norms very much opposed to those conventionally associated with the legal treatment of parenthood.

\section{B. THE LAW OF CHILD CRUELTY}

\section{The New York Society for the Prevention of Cruelty to Children}

The New York Society for the Prevention of Cruelty to Children was formally a private organization, founded, led, and largely funded by some of the most prominent and wealthy philanthropists of its day. ${ }^{123}$ Yet it immediately sought, quickly won, and eagerly exercised unprecedented legal authority to scrutinize its targeted families, remove their children, and arrest their parents. ${ }^{124}$ The society and its empowering legislation regulated the rights, responsibilities, and relationships of family members, but its work was not understood to fall within the jurisdiction of family law, and it operated on principles at odds with family law as it was authoritatively defined. ${ }^{125}$

The New York society's standard for determining which parents merited the deference traditionally accorded at common law, and which did not, had familiar outlines, now codified into positive law. The society did not seek to overturn parental prerogatives in every arena; it only saw child cruelty in certain social forms and not others. In particular, the society operated on the overriding principle that both children and the nation at large would be endangered if the law respected the judgment and household autonomy of either parent in families without a father able to adequately support his wife and children and to keep them out of market labor. In this vision, cruelty was defined as a deviation from ideal domesticity, but not necessarily the use of violence. This standard of parental failure turned on practices strongly associated with people of little means, and the society's caseload, like that of its more fully private predecessors in elite philanthropy, ${ }^{126}$ was exclusively poor. ${ }^{127}$

122. See id. at 231-32 ("[T]here was usually a dense crowd of people at the station, awaiting the arrival of the youthful travelers .... [M] any who really wanted the children's labor pressed forward to obtain it."); To Farmers and Mechanics and Manufacturers in the Country from the Children's Aid Society (Mar. 1853), reprinted in Henry W. Thurston, The Dependent Child: A Story of Changing Aims and Methods in the Care of Dependent Children 100, 101 (1930) ("There would be no loss in the charity. These boys are, many of them, handy and active, and would learn soon any common trade or labor. They could be employed on farms, in trades, in manufacturing . . . The girls could be used for the common kinds of housework." (original emphasis omitted))

123. See supra notes $11-12$ and accompanying text.

124. See supra text accompanying notes 16-24.

125. See supra Part I.B.

126. See supra Part II.A.

127. On rare occasion, the society happened to cross paths with a wealthy child. It encountered, for instance, two wealthy orphans in its early years. See The New York Society for the Prevention of 
Although the child whose plight initially sparked the formation of the New York society had been the victim of physical abuse, ${ }^{128}$ the society always viewed the question of physical violence ambiguously. From the start, it supported a parent's right to corporally punish his child. Henry Bergh, soon to become a vice president of the New York society, ${ }^{129}$ explained at an organizational meeting in December 1874 that he was "anxious to protect children from undue severity," but still "in favor of good wholesome flogging, which he often found most efficacious." 130

Over time, the New York society appears to have become less certain that even excessive physical violence was central to the problem of child cruelty. In the 1890s, Elbridge Gerry, the president and guiding force behind the society, campaigned (unsuccessfully) in New York for laws subjecting "child cruellists" to the whipping post. ${ }^{131}$ The effort revealed, very dramatically, Gerry's assump-

Cruelty to Children, First Annual Report, supra note 23, at 33-34 ("[V]ery respectable citizens testified ... that he was possessed of considerable property in real estate and money; that both parents were dead, his mother dying in March last; ... and that evil-minded persons, both men and women, were assisting to ruin him, and squander his property."); THE NEw YORK SOCIETY FOR THE PREvention OF Cruelty to Children, supra note 18, at 10 ("Charles F. Barrett, found among the street gamins in San Francisco, Cal., by the Society there, and upon investigation it was ascertained that he had run away from Boston, Mass., some time previous; that parents had died during his absence, leaving considerable property."). But the society dealt with these children outside of its usual procedures, by arranging guardians for them. See The New York Society for the Prevention of Cruelty to Children, First ANNUAL REPORT, supra note 23, at 34 ("Judge Loew appointed Henry Kugeler, a wealthy gentleman, residing near the boy's property, guardian. Mr. Kugeler has filed bonds in the sum of $\$ 30,000$ dollars for the faithful performance of his trust."); The New York Society for the PREvention of Cruelty to Children, supra note 18, at 10 ("A proper guardian was appointed, and boy forwarded per steamer to New York, and received by this Society and forwarded to Boston, where he is now attending school, having given up his roaming propensities, as we are informed.").

128. See supra text accompanying note 7.

129. See John D. Wright Dead, supra note 12.

130. Prevention of Cruelty to Children, supra note 7 (reporting remarks of Henry Bergh).

131. See Elbridge T. Gerry, Must We Have the Cat-O'-Nine Tails?, 160 N. AM. REv. 318, 323 (1895) (advocating " $[\mathrm{t}]$ he present proposed legislation, which has the sanction of all the humane societies in the State of New York, and was prepared by their Committee on Legislation pursuant to their instructions"); The New York Society for the Prevention of Cruelty to ChIldRen, Twenty-First ANNUAL REPORT 7 (New York, no publisher 1896) ("Corporal punishment has been suggested as a very practical method of dealing with the evil, on account of its deterrent effect. Last year the Legislature of this State failed by a few votes to pass such a measure.").

John G. Shortall, the president of the Illinois Humane Society, also supported the whipping of child cruellists. See Thirtieth Annual Report of the Lllinois Humane Society 5, 56 (Chicago, Illinois Humane Society 1899) ("Shortall ... drew up a bill which was presented to the Legislature . . , asking for the enactment of a law making whipping a penalty under the criminal statutes, for certain offenses. The bill was introduced, but failed of present adoption. It was not expected that it would be adopted at once...."). The Illinois Humane Society was the local equivalent of a Society for the Prevention of Cruelty to Children. See infra text accompanying notes $175,182$.

For similar advocacy, see Flogging for Wife-Beaters, PHILA. INQUIRER, May 8, 1899, at 8 ("There is a growing sentiment that for the brute who beats his wife [or] who ill-uses children ... a short term of imprisonment is an inadequate and ineffective penalty, and the opinion is gaining ground that for such offenses the whipping post ... constitutes the only appropriate and deterrent punishment."); and The 
tions about the sort of parents who committed child cruelty. Gerry supported "the infliction of physical pain," on the ground that the rod was "an argument" that parents could "appreciate, no matter how illiterate they are, or how debased by crime, or how besotted by indulgence in liquor."132 More broadly, this campaign endorsed serious physical violence as a means of securing obedience to legitimate hierarchy, whether between the state and these particular citizens or between parent and child. In the course of his campaign for the whipping of child cruellists, Gerry made the case for the corporal punishment of children in similarly authoritarian terms, explaining that "corporal punishment is recognized in every household in the land, as a speedy and effective method of reducing an unruly child to submission; and while in very many cases it should be the last argument resorted to, it certainly has the advantage of producing an immediate compliance."133

The society's practice accorded closely with Gerry's views on the issue of physical violence. By 1893, Superintendent E. Fellows Jenkins, the man assigned to tabulate and summarize the work of the society's agents, was reporting that "fewer cases of actual physical cruelty are found," leaving the society free to focus on "neglect and moral cruelty ..., as well as many other wrongs to children." 134 Jenkins had no independent means of tracking the incidence of physical violence against children in New York City; what he was really reporting was that the society's agents were arresting fewer parents and removing fewer children on grounds of physical abuse. The New York society's campaign against child cruelty was not necessarily a campaign against violence. Indeed, the society understood much violence against children to be perfectly legitimate, and cruelty to be mostly something other than violence.

Rather than concentrate on physical abuse (or on other features of the interaction between parent and child), the society devoted its most intense energy to another problem, that of children in the commercial public, earning

Whipping-Post, WASH. PosT, May 22, 1899, at 6 ("A drunken brute capable of beating his helpless wife and maiming his innocent children recognizes no terrors in the modern prison .... The one thing he fears, and, therefore, the one deterrent he is capable of appreciating, is physical suffering.").

132. Gerry, supra note 131, at 320-21; see also The New York Society for the Prevention of CRUELTY to ChILDREN, supra note 131, at 6-7 ("[M]ore stringent measures [are] necessary to lessen successfully ['the record of crimes committed against the helpless children of the poor'] .... The human brute who seeks his victim in helpless childhood dreads imprisonment but little, if at all. Pain is the one thing to which he is not insensible."); John G. Shortall, To the Honorable the Members of the Forty-First Legislature of Illinois, Assembled at Springfield, in Thirtieth AnNual Report of the IlliNois HuMANE SocieTY, supra note 131, at 56, 57 ("We demand . . punishment which has a deterrent quality. No punishment has that quality for the person to whose fine nature you cannot appeal, except physical pain.").

133. Gerry, supra note 131, at 322; see also Shortall, supra note 132, at 57 ("From the days of Solomon it has been well known that when the rod is spared the child is spoiled. We believe it to be true to-day.").

134. The New York Society for the Prevention of Cruelty to Children, Eighteenth Annual REPORT 18 (New York, no publisher 1893). 
money by begging, ${ }^{135}$ peddling, ${ }^{136}$ or performing. ${ }^{137}$ The society understood a child in commercial life to be per se evidence of a parent's "cruelty." Its attention focused most sharply on those children whose labor was visible to a general audience, ${ }^{138}$ and it was quick to spot commerce in the street activities of poor children, easily concluding that the purportedly free performances that many of these children offered, for instance, were only veiled forms of solicita-

135. See, e.g., The New York Society for the Prevention of Cruelty to Children, First Annual REPORT, supra note 23, at 36 ("Sept. 22. Sarah Quinn, arrested with child about three years old, for begging .... Maggie Solferino arrested for begging .... Michael Brennan, aged nine years, arrested twelve o'clock at night for begging .... Malachia Brennan, six years old, arrested for begging .... [All were] [t]aken before Judge Wandell and committed....”); THE NEw YORK SOCIETY FOR THE Prevention of Cruelty to Children, Second Annual Report 41 (New York, Styles \& Cash 1877) (reporting commitment of child for begging and noting that child's "parents were Italians, strong, able-bodied persons, and were evidently living almost wholly from his efforts, his receipts being many times two and three dollars per day"); The New York Societr for the Prevention of Cruelty to CHILDREN, supra note 18, at 14-15 (reporting that parents of arrested child beggar refused "to keep him home ... as [the] boy was undoubtedly a source of large revenue to them"); see also People v. Malone, 71 N.Y.S. 224, 224-25 (App. Div. 1901) (reversing parent's conviction where the New York society found his child begging, on the ground that there was no evidence "that the parent neglected or refused to use the ordinary and proper means to restrain him from begging").

136. See The New York Society for the Prevention of Cruelty to Children, Fifth Annual Report 9 (New York, Styles \& Cash 1880) [hereinafter The New York Society for the Prevention of Cruelty to Children, Fifth Annual. RePort] (asserting that "[m]iserable little girls, compelled to sell flowers at the doors of places of vile resort-their business often being a cover for shameful practices-no longer loiter there night after night"); The New York Society for the Prevention of Cruelty to Children, Eleventh AnNual Report 6-7 (New York, no publisher 1886) [hereinafter The New York Society for the Prevention of Cruelty to Children, El.eventh Annual Report] ("[T] he practice [of child cruelty] is carried to the extremes of educating children to beg, to peddle, to steal, and even to immorality, simply to put money in the pockets of their parents, and without the slightest thought as to the consequences to the children or to society ....").

137. See In re Stevens, 24 N.Y.S. 780, 780-81 (Sup. Ct. 1893) (upholding conviction for publicly exhibiting a child in a theatrical performance, in case in which defendant was arrested "at the instance of the New York Society for the Prevention of Cruelty to Children"); People v. Meade, 10 N.Y.S. 943, 943-44 (Ct. Gen. Sess. 1890) (recording jury instructions in successful prosecution that New York society brought for employing children in a theatrical performance); THE NEw YORK SOCIETY FOR THE Prevention of Cruelty to ChILdRen, First Annual Report, supra note 23, at 39 (reporting arrest of seven year-old boy "called 'Prince Leo"" who performed on a tight rope); THE NEW YORK SOCIETY FOR the Prevention of Cruelty to Children, Fifth Annual Report, supra note 136, at 66 (reporting commitment of 'Frederick Klinket, aged eleven years, known as 'Young Barbadoes,' [who was working] as a contortionist").

138. Indeed, the society commonly described children who earned money in public as an infliction on the respectable adults who encountered them. See, e.g., THE NEw York Society for THE Prevention of CRUelty to Children, Nineteenth Annual Report, supra note 17, at 8 ("[T]he streets of this great city are no longer filled with very small children, begging, peddling and pilfering, to the annoyance of all decent people."); The New York Society for the Prevention of Cruelty to Children, supra note 18, at 14 (reporting arrest of "Frank Haller, aged ten years, a crippled beggar boy-one of the worst sights with which our city was inflicted. He was so badly deformed that he could not walk erect, but slid along the pavement, upon his hands and feet, through the snow and ice."); THE NEw York SocIETY FOR THE PReVention of CRuelty to Children, supra note 135, at 41 (reporting arrest of "Francesco Verize, a cripple boy, aged fifteen years" for begging and noting that "if persons from whom he solicited alms did not comply with his request, he would insult them"). 
tion. ${ }^{139}$ It successfully lobbied for the passage of a series of statutes that codified its views into law. As early as 1876 , a parent was guilty of a criminal offense and liable to lose permanent custody of his child whenever the child participated in "the vocation, occupation, service, or purpose of singing, playing on musical instruments, rope, or wire walking, dancing, begging, or peddling, or [performed] as a gymnast, contortionist, rider or acrobat, in any place whatsoever." 140 With less fervor (and less legislative success), the New York society also opposed child labor in factories. ${ }^{141}$

139. Statutes enacted in this era often similarly treated adult street performances as prohibited forms of begging. The Massachusetts criminal code of 1860 , for instance, punished "persons who use any juggling or unlawful games or plays, common pipers and fiddlers," along with explicit beggars. MASs. GEN. STAT. ch. 165, $\S 28$ (1860). For an excellent description of the street culture of poor people in nineteenth-century New York, see STaNSELL, supra note 82, at 50-51, 56-57, 203-05.

140. An Act to prevent and punish wrongs to children, ch. 122, $\S \S 1,3,1876$ N.Y. Laws 95, 95-96. The statute contained exceptions for singing or playing a musical instrument in church or school and for playing an instrument with "the written consent of the mayor of the city or president of the board of trustees of the village where such concert or entertainment shall take place." Id. $\S 1$. An earlier New York statute, enacted on April 3, 1874 just before Bergh and Gerry began organizing the New York society, subjected parents to the possibility of a fine and/or imprisonment if they sold, apprenticed, gave away, let out, or disposed of a child to someone who used the child for begging, peddling, or street performing. See An Act in relation to mendicant and vagrant children, ch. 116, § 1, 1874 N.Y. Laws 132, 132. This 1874 statute, however, was significantly less far-reaching than the 1876 act. Most notably, the earlier law did not authorize the deprivation of custody. See id.

For more examples of statutes passed after the New York society's founding that reflected its influence, see An Act for the protection of children, and to prevent and punish certain wrongs to children, ch. $428, \S \S 2-3,1877$ N.Y. Laws 486,486 (providing that a parent who failed to restrain his "child from begging, whether actually begging or under the pretext of peddling" was guilty of a criminal offense and subject to losing custody of his child); An Act to amend chapter four hundred and twenty-eight of the laws of eighteen hundred and seventy-seven, entitled 'An act for the protection of children and to prevent and punish certain wrongs to children,' and to repeal chapter forty-eight of the laws of eighteen hundred and fifty-nine, ch. 496, § 2, 1881 N.Y. Laws 669, 669 (providing criminal penalties for a parent who "permit[ted] or neglect[ed] to restrain [his] child from begging, gathering, picking or sorting of rags, or from collecting cigar stumps, bones or refuse from markets"); An Act to amend the Penal Code, ch. $31, \S 5,1886$ N.Y. Laws $39,40-41$ (providing criminal penalties for a parent whose child was, inter alia, performing circus tricks, "begging or receiving or soliciting alms," "gathering or picking rags, or collecting cigar stumps, bones or refuse from markets," or "peddling, singing or playing upon a musical instrument, or in a theatrical exhibition, or in any wandering occupation"); and An Act to amend section two hundred and ninety-two of the Penal Code relative to the licensing of children in theatrical exhibitions, ch. 309, § 1, 1892 N.Y. Laws 632, 632 (similar).

Within a decade after the New York society's establishment, the most influential reform lawyer in New York, David Dudley Field, was urging the institutionalization of children who lived with their parents but spent their days, "ragged and dirty, ... pick[ing] up rags, cigar stumps, and other refuse of the streets, or ... pilfer[ing] or beg[ging]." David Dudley Field, The Child and the State, 1 Forum 105, $106(1886)$.

141. The society did not begin to lobby for a child labor law for children in manufacturing until 1882. See Editorial, N.Y. Times, Feb. 16, 1882, at 4; Mary Stevenson Callcott, Child labor Legislation in New York 9 (1931); Fred Rogers Fairchild, The Factory Legislation of the State of New York 39 (American Economic Association Publication No. 4, 1905); Jeremy P. Felt, Hostages of Fortune: Child Labor Reform in New York State 8-9 (1965); Jeremy Pollard Felt, The Regulation of Child Labor in New York State, 1886-1942, at 19-21 (1959) (unpublished Ph.D. dissertation, Syracuse University) (on file with author). The state legislature did not enact its first law in that area until four years later. See An Act to regulate the employment of women and children in manufacturing establishments, and to provide for the appointment of inspectors to enforce the same, ch. $409,1886 \mathrm{~N}$.Y. Laws 
This definition of cruelty conditioned legal respect for parental prerogatives on the ability to achieve the family-market ordering idealized in the literature of domesticity, operating on the assumption that a child's contribution to his family's maintenance was a mark of parental failure, indolence, and wilful exploitation. On the society's account, huge portions of the children begging on the streets were not "driven to it by actual want and suffering," but instead had been "sent out merely to support parents in a life of vice and drunkenness." In fact, the society was also certain that the prevalence of families without a father who kept his dependents from market labor reflected, more particularly, the racial degeneracy of foreign-born populations ill-suited for self-government, whether in the household or outside it. ${ }^{143}$ Child labor had deep roots in the American tradition, ${ }^{144}$ and it remained quite common in the nineteenth century, ${ }^{145}$ despite the growing opposition of middle-class reformers. ${ }^{146}$ But the New York society systematically characterized the practice as an "antiAmerican" import, nonetheless. ${ }^{147}$ "The foreign theory," the society explained

629. The society's annual reports would occasionally note "that no child should toil in the factory." THE New York Society for the Prevention of Cruelty to Children, Fourteenth Annual Report, supra note 17, at 14; see also The New York Society for the Prevention of Cruelty to Children, Eleventh ANNUAL REPORT, supra note 136, at 7 ("[This society] joins hands with the workingmen, who have at last aroused to the fact that their children are being ruined in factories, in their efforts to secure proper legislation ...."). But they did not dwell on the issue. See Gerry's Odd Actions, supra note 12 ("The care with which Mr. Gerry refrains from interfering with the thousands of miserable children who are allowed to work in factories and crowded stores in New York is quite as expressive as the vigor with which he exercises his authoritative powers on the children of the stage.").

142. The New York Society for the Prevention of Cruelty to Children, First Annual Report, supra note 23, at 26; see also Gerry, supra note 12, at 128 ("Only those who are degraded far below the level of the brute creation ... by a shameless submission to degrading passions, compel such little children by their pitiful condition to extract alms from the compassionate for their support, or for the procurement of the means of vicious indulgence.").

Even before the advent of the New York society, a wave of nineteenth-century states passed harsh new laws criminalizing begging and vagrancy by adult men. See generally STANLEY, supra note 56, at 99-100, 108-11. These laws were similarly justified on the ground that legal coercion was needed to protect the foundation of the social order from men who were deliberately choosing to avoid work and responsibility. See id. at 103 ("Most beggars were said to be 'idle from choice,' not 'necessity' .... Supposedly, the beggar only pretended to seek work, "coining his unblushing falsehoods as fast as he can talk' ...." (citations omitted)); id. at 107 ("['[C]harity reformers'] attributed the dependence of an able-bodied man on alms to his depravity, disinclination, and skill in avoiding the 'discipline of hunger and cold.' Regarding wage labor as the obverse of dependency, they postulated that beggars simply lacked compulsion to work." (citation omitted)).

143. See supra text accompanying notes $95-98$.

144. See John Demos, A Little Commonwealth: Family Life in Plymouth Colony 140 (1970) (reporting that "[s]ix to eight seems to have been the most common age" at which children in the Plymouth Colony were apprenticed to work); Edmund S. Morgan, The Purttan Family: Religion \& Domestic Relations in Seventeenth-Century New England 66 (rev. ed. 1966) ("Probably most children were set to some kind of useful work before they reached seven. Certainly Puritan spokesmen emphasized the dangers of idleness more than the permissibility of play."); ZELIZER, supra note 66, at $59-60$.

145. See supra text accompanying notes 84-85.

146. See supra text accompanying notes $62-69$.

147. The New York Society for the Prevention of Cruelty to Children, Eleventh Annual RePort, supra note 136, at 6; see also Arthur Hornblow, The Children of the Stage, Munsey's MaG., 
in a phrase equating child cruelty with the burgeoning immigrant population, "is that children are the property of their parents, to be utilized as the latter see fit." 148 "The American theory is, that it is rather the duty of the parents to support the child."149

Deferring to the decision making and authority of these parents would, the society was convinced, have dire and inevitable consequences for the children at issue and the nation as a whole. If left unscrutinized, unregulated, and with custody of their offspring, these failed and patently immoral parents would contaminate their children's innocence to the point of threatening the foundations of the social order. The society predicted that boys cravenly forced to labor in the market would grow up to "swell the ranks of the "dangerous classes' which imperil the public peace and security," who grow up in an atmosphere of vice mature into criminals as a matter of course." 151 The girls, for their part, would be similarly corrupted, although their degradation and the blight they imposed on the public would take a different form. In the society's vision, market labor in a girl's youth led quickly and inexorably to participation in a yet more immoral and inappropriate form of commerce, namely prostitution. ${ }^{152}$ ““[I]t therefore follow[ed],", the society

Oct. 1894, at 32, 35-36 ("What is so abominable, so infamous, as to see healthy parents, perfectly able to earn their own living, forcing their children to support then? It is wrong; it is anti American; it is disgraceful."' (quoting Gerry)).

148. The New York Society for the Prevention of Cruelty to Children, Fourteenth Annual REPORT, supra note 17 , at 14.

149. Id.; see also The New York Society for the Prevention of Cruelty to Children, Eleventh ANNUAL REPORT, supra note 136, at 5, 8 ("[The] foreign theory [is] that children are merely the property of their parents, and to be utilized as they see fit for their pecuniary profit and benefit .... The proof of this appears in the nationality of the offenders. The statistics show a very small percentage of Americans as cruellists."); Elbridge T. Gerry, Children of the Stage, 151 N. AM. REv. 14, 18 (1890) ("The law compels parents to support their children during their tender years, and nowhere sanctions the reverse of this rule. If parents are unable to provide for their children, the law provides institutions for that purpose.").

150. The New York Society for the Prevention of Cruelty to Children, supra note 135, at 6.

151. The New York Society for the Prevention of Cruelty to Children, Twentieth Annual REPORT 5 (New York, no publisher 1895) (celebrating "[t]wenty years of earnest, hard work in this great city involving the custody of over 230,000 little outcasts most of whom but for the interference of the Society would to-day be mature criminals"); see also THE NEW YORK SOCIETY FOR THE PreveNTION OF Cruelty to ChILdRen, Fourteenth AnNual Report, supra note 17, at 5 ("A career in crime is usually based upon early vicious surroundings, the absence of proper religious training in the young, evil associations and frequent contact with vice.... [U]nless prompt measures are taken with the growing children, there can be but little diminution of the number of criminals as the population of this great country steadily increases.").

152. See The New York Society for the Prevention of Cruelty to Children, supra note 135, at 6 (reporting that child cruelty left girls "lost_-body and soul—often before they are women in age and maturity"). The society was especially concerned about girls who performed in public for pay. See THE New York Society for the Prevention of Cruelty to Children, Fifth AnNual Report, supra note 136, at 10 (noting that "the recorded instances of female ruin and criminal acts, originating in the miscellaneous companies and evil associations connected with these performances, more than sustain the wisdom of the action of this Society"); id. at 78, 80 (reporting that " [m] any of the girls [performing in theatrical exhibitions] become prostitutes at an early age, and finally end in low dance houses and concert salons," while the boys "'ultimately end by being thieves or tramps" (quoting "President 
explained, "'that not only [was] removal best for the[se] children," it was "'best for the country at large, as a preventative for the increase of crime and pauperism."”153

Drawing on deep cultural impulses, the society effectively summarized and defended its operating principles in a rhetoric of domesticity, explaining that the children it targeted lived with their parents but had no real households that the law could recognize or respect. From the society's first statement of purpose, it made clear that it intended to rescue "little unfortunates" "from the dens and slums of the City." 154 This description contained explicit expectations about the class composition of the population that the society was seeking to regulate; the word "slum" could hardly encompass a wealthy or middling neighborhood. But the term "dens and slums" spoke about class in an idiom that the society took to be particularly apt. From the outset, the society consistently refused to employ the language of home and domesticity to describe the families it was monitoring, managing, and separating. Instead, the society reported that it was removing children from the " $m i s c a l l e d$ homes of the inebriate," 155 or the dwellings of those "unfamiliar with the meaning of that word ['home'] in its American sense." ${ }^{156}$ Indeed, the society could not have presented the contrast in domesticity more starkly. On its account, children raised in "surroundings of vice and

Gerry's letter to the Secretary of the Cleveland Humane Society, in response to an inquiry made as to what the New York Society's views were in regard to allowing children of tender age to appear in public")); Gerry, supra note 149, at 18 (explaining that girls in public performances "soon lose all modesty and become bold, forward, and impudent. When they arrive at the limit-age of the law, they have usually entered on the downward path and end in low dance-houses, concert-saloons, and the early grave which is the inevitable conclusion of a life of debauchery."); see also In re Donohue, 52 How. Pr. 251, 254 (N.Y. Sup. Ct. 1876) (conflating the employment of children in circus productions with holding "female children ... for purposes of prostitution").

153. The New York Society for the Prevention of Cruelty to Children, fourteenth Annual. REPORT, supra note 17, at 19 (quoting "an able thinker and writer upon this subject").

154. Protection for Children, supra note 7 (reporting remarks of Elbridge Gerry); see also ConstrTUtion and By-Laws of the New York Society for the Prevention of Cruelty to ChILdRen, supra note 23 , at 5 (same).

155. The New York Society for the Prevention of Cruelty to Children, Fourth Annual Report 6 (New York, Styles \& Cash 1879) (emphasis added) (quoting the American Female Guardian Society).

156. The New York Society for the Prevention of Cruelty to Children, Nineteenth Annual RePort, supra note 17, at 6. For additional examples, see The New YORK SOCIETY FOR THE PREveNTION OF CRUElTY to CHILDREN, supra note 18, at 5 ("the most degraded and vicious surroundings"); THE NEW York Society for the Prevention of Cruelty to Children, Seventh Annual Report, supra note 11, at 5 ("the slums and dens of the city"); The New York Society for the Prevention of Cruelty to Children, Elghth Annual Report 8 (New York, Styles \& Cash 1883) [hereinafter The New York Society for the Prevention of Cruelty to Children, Eighth Annual Report] ("the slums and gutters of the city"); The New York Society for the Prevention of Cruelty to Children, Ninth Annual RePort 6 (New York, no publisher 1884) [hereinafter The New York Society for the Prevention of Cruelty to Children, Ninth AnNual Report] (“dens of wretchedness and physical suffering”); The New York Society for the Prevention of Cruelty to Children, Tenth Annual Report, supta note 23, at 8 ("vicious surroundings"); The New York Society for the Prevention of Cruelty to Children, Eleventh ANNUAL RePORT, supra note 136, at 5 ("surroundings of vice and ignorance"); ThE New York Society for the Prevention of Cruelty to Children, Thirteenth Annual Report 11 (New York, no publisher 1888) ("the cesspool of vice, and crime, and suffering"); THE NEw YORK SOCIETY FOR THE Prevention of Cruelty to Children, Fourteenth Annual Report, supra note 17, at 19 ("low, vicious 
ignorance" by their parents actually reached true "homes" when they were institutionalized at the society's behest. ${ }^{157}$ These child care institutions were, obviously, not the precise sort of homes that the literature on domesticity envisioned. But they did keep their charges out of the public marketplace and place them under constant supervision. ${ }^{158}$ The society took this to be a sufficient approximation of the requirements of ideal domesticity-one it promised was far better than what parents who "regard[ed] their children as simple puppets to be utilized in making money for them" had accomplished. ${ }^{159}$

\section{The Child Cruelty Movement}

The New York society's approach proved remarkably successful, in the state legislature and nationwide. In the last quarter of the nineteenth century, Societies for the Prevention of Cruelty to Children spread like wildfire across the United States, with the heaviest concentration in the Mid-Atlantic states and the Midwest. By the end of 1879 , there were four other cruelty societies in New

surroundings"); and The New York Society for the Prevention of Cruelty to Children, TwentyFOURTH ANNUAL REPORT, supra note 11, at 7 ("atmospheres of poverty and crime").

The New York society used this language of failed domesticity so consistently that outsiders soon described the society's work in the very same terms. Reformer Jacob Riis, for instance, characterized the society's clients as "little savages ... hauled forth from their dens of misery." JACOB A. RIIS, ThE ChILdRen OF THE Poor 143 (New York, Charles Scribner's Sons 1892). Justice Martin of the New York Court of Appeals similarly reported that "[t]he class of children which the [society] seeks to benefit is found in the slums and dens of a metropolitan community." People ex rel. State Bd. of Charities v. N.Y. Soc'y for the Prevention of Cruelty to Children, 55 N.E. 1063, 1074 (N.Y. 1900) (Martin, J., dissenting).

157. The New York Society for the Prevention of Cruelty to Children, Eleventh Annual Report, supra note 136, at 5; see also The New York Society for the Prevention of Cruelty to ChILDREN, supra note 18, at 7 ("Societies having the care of children in our city and through the country have forwarded their reports, thus placing us in a position to find homes for the little ones coming under our charge ...."); The New York Society for the Prevention of Cruelty to Children, Eighth ANNUAL REPORT, supra note 156, at 8 (praising the institutions where it placed children "for their efforts to provide homes for the little waifs after they are rescued from the slums and gutters of the city"); THE New York Society for the Prevention of Cruelty to Children, Twenty-Fifth Annual Report 11 (New York, no publisher 1900) (reporting that the society had placed "over 80,000 [children] in comfortable homes under moral influences," meaning child care institutions in the overwhelming number of cases).

158. See The New York Society for the Prevention of Cruelty to Children, Seventh Annual REPORT, supra note 11, at 5 (explaining that the society's "officers go into the slums and dens of the city, remove helpless and wronged children by the strong arm of the law, and place them, by the aid of the Courts, in the Institutions who receive children, reform their vicious habits, [and] give them moral and intellectual training"); The New York Society for the Prevention of Cruelty to ChILdRen, NinTH ANNUAL REPORT, supra note 156, at 6 ("What now constitutes the value of an Institution is not the number of children it receives and for the support of which it is paid either by private individuals or by the State or City, but the proportion of those children which it can point to, as finally saved.").

159. The New York Society for the Prevention of Cruelty to Children, Nineteenth Annual REPORT, supra note 17, at 6. David Dudley Field similarly described the institutionalization of children who lived with their parents but spent significant time earning money in the streets. "This," he wrote in 1886, "is to transfer the child from an unclean home to one that is clean, from indecency to decency, from foul air to pure, from unhealthy food to that which is healthy, from evil ways to good." Field, supra note 140, at 108 (emphasis added). 
York State, ${ }^{160}$ and sixteen more outside New York. ${ }^{161}$ By the end of 1884 , fifty-six cruelty societies had been formed in the United States in addition to the one in New York City. ${ }^{162}$ These societies were independently organized and run, but there was a broad overlap in goals and commitments. Like the New York society, the sister organizations were founded on the premise that it would be inappropriate and unsafe for the law to continue to defer to parents who had not achieved the family-market ordering celebrated in the ideology of domesticity. Throughout the country, cruelty societies demanded, obtained, and enforced new bodies of law that scrutinized, regulated, and reshaped families without a father able to adequately provide for his wife and children and protect them from market labor. ${ }^{163}$

Consider the Massachusetts Society for the Prevention of Cruelty to Children, founded in Boston in 1878. ${ }^{164}$ The Massachusetts society, nationally influential in its own right, did not follow New York's lead in all respects. The New York society's first instinct was to prosecute parents and commit children. The Massachusetts society thought it more effective to give parents some opportunity to reform their home lives under supervision, ${ }^{165}$ although it ultimately removed large numbers of children from their parents. ${ }^{166}$ The Massachusetts society also preferred to place children in foster care instead of the institutions that the New York society favored. ${ }^{167}$

But the Massachusetts officers agreed with New York about the nature of the

160. The New York Legislature helped encourage this development. The incorporation statute for the New York Society for the Prevention of Cruelty to Children provided that any five or more people could join together to incorporate a local cruelty society within New York State. See An Act for the incorporation of societies for the prevention of cruelty to children, ch. $130, \S \S 1-2,1875$ N.Y. Laws $114,114$.

161. See The New York Society for the Prevention of Cruelty to Children, Fifth Annual. REPORT, supra note 136, at 9.

162. See The New York Society for the Prevention of Cruelty to Children, Tenth Annual REPORT, supra note 23, at 9; see also Folks, supra note 24, at 177 ("In only one state [Indiana] have governmental bodies been created to perform the duties elsewhere assumed by these societies [for the prevention of cruelty to children].").

163. In 1924, William J. Shultz tabulated each state's position, as of 1922, on a variety of offenses against children. He found that twenty-four states and the District of Columbia criminalized the exhibition of children on the stage, twenty-three states and the District of Columbia criminalized child begging, and eight states criminalized child peddling. See William J. Shul.tZ, The Humane Movement in THE UNITED STATES, 1910-1922 app. II at 275-77 (1924).

164. See Massachusetts Society for the Prevention of Cruelty to Children, First Annual RePort 5 (Boston, Wright \& Potter Printing Co. 1882) (Massachusetts society's charter).

165. See id. at 22 ("When the home life is not degraded, or can be essentially improved, it is better not to separate parent and child.").

166. Linda Gordon, who reviewed a sample of the confidential case records kept by the Massachusetts society, found that "[b]etween 1880 and 1920, seventy-four percent of the neglected children of single mothers were taken from those mothers by the MSPCC." Linda Gordon, Single Mothers and Child Neglect, I880-1920, 37 AM. Q. 173, 191 (1985).

167. See Massachusetts Society for the Prevention of Cruelty to Children, supra note 164, at 22 ("[I]nstitution life is not the natural life for children, and does not fit them for the best manhood and womanhood."); Massachusetts Society for the Prevention of Cruelty to Children, Ninth Annual RePort for 1889, at 13 (Boston, Wright \& Potter Printing Co. 1890) ("While we are obliged to send 
problem that they were confronting. Here, as in New York, the child cruelty society was much less concerned with physical abuse, and much more interested in holding parents criminally liable when their children occupied public space for commercial purposes. As early as 1883 , the Massachusetts society reported that its caseload reflected "a lessening of the number of cases of extreme cruelty by blows and other methods of physical torture." 168 In its eyes, the problem of child labor loomed larger and more dangerous, especially when that labor took place in public arenas. Like the New York society, the Massachusetts organization understood a child's peddling, begging, or performing to be conclusive evidence of parental cruelty, certain that the money these children earned went "often to gratify the appetite of a drunken father or mother, or both." 169

As New York had before it, the Massachusetts society convinced state legislators to create new forms of positive law that strictly limited the control that these particular parents exercised over their children. At the urging of the Massachusetts society, the Massachusetts Legislature agreed in 1882, for instance, to subject a parent to criminal punishment if he permitted the employment or exhibition of his "child under fifteen years of age, in dancing, playing on musical instruments, singing, walking on a wire or rope, or riding or performing as a gymnast, contortionist, or acrobat, in any circus or theatrical exhibition, or in any public place whatsoever." ${ }^{170}$ In 1884 , the legislature prohibited any public exhibition of deformed children. ${ }^{171}$ Three years later, the state also agreed to subject the parents of child peddlers and child beggars to strict criminal regulation. ${ }^{172}$

This conviction that child cruelty, and the need for legal intervention to limit

many children to institutions by order of court, we know their final destination should be a good family.").

168. Massachusetts Society for the Prevention of Cruelty to Children, Annual Report for 1882, at 13 (Boston, Wright \& Potter Printing Co. 1883).

169. Massachusetts Society for the Prevention of Cruelty to Children, Fourth Annual Report FOR 1884, at 22-23 (Boston, Wright \& Potter Printing Co. 1885) (campaigning for stringent criminal regulation of child peddling); see also MAssachusetTs Society for the Prevention of Cruelty to Children, Third Annual Report for 1883, at 21 (Boston, Wright \& Potter Printing Co. 1884) (supporting criminal penalties for parents who place their children in public performances on ground that "[t]he children are deprived of needed education, are kept from their beds till 11 P.M., are exposed to a life of excitement and wandering, as members of variety troupes, or at cheap shows"); id. (objecting to exhibitions "of deformed and mal-formed children").

170. Of the Employment of Children, and Regulations Respecting Them, Mass. Pub. Stat. ch. 48, $\S 8$ (1882). The statute recognized some exceptions for performances in church, school, or "on the special written permission of the mayor and aldermen of a city or of the selectmen of a town." Id.; see also Massáchusetts Society for the Prevention of Cruelty to Children, supra note 168, at 22-24 (arguing that the statute did not go far enough).

171. See An Act to prohibit the exhibition of deformities for hire, ch. 99, $\$ 1,1884$ Mass. Acts 78 , 78.

172. See An Act to prevent illegal peddling and begging by certain minors, ch. 422,1887 Mass. Acts 1087, 1087-88 ("Any parent . . . who [requires or permits his child] under the age of fifteen years, [to engage] in peddling without a license, when a license is required by law, or in begging,... shall be punished by a fine not exceeding two hundred dollars, or by imprisonment not exceeding six months."). 
parental authority, turned primarily on failed family-market orderings was widespread in the last quarter of the nineteenth century. ${ }^{173}$ Illinois provides another illustrative example. As early as 1877 , the state legislature enacted an anticruelty statute providing that parents could be imprisoned and lose permanent custody of their children if they allowed their children to participate in "the vocation or occupation, service, or purpose of singing, playing on musical instruments, rope or wire walking, dancing, begging or peddling, or as a gymnast, contortionist, rider or acrobat."174 Prompted in part by this law, the

173. The Brooklyn Society for the Prevention of Cruelty to Children, for instance, also operated on this view. As it noted after only three years in operation, its attention was increasingly "directed to little street beggars," along with the children who swept the streets, or "peddle[d] some small wares, which is only a cloak for begging." The Brooklyn society, much like its counterparts in Manhattan and Boston, took such commercial activities to be certain proof that the child laborers had "brutal and often drunken parents" who had "forced" their children to earn money out of greed and indolence. THE BROOKLYN Society for the Prevention of Cruelty to Children, Third Annual Report 4 (Brooklyn, Union Book \& Job Printing Establishment 1883).

The Queen City Society for the Prevention of Cruelty to Children, based in Buffalo, New York, similarly reported that it had prevented " $[\mathrm{m}]$ any children ... from begging, thereby saving them from that training school to pauperism and crime.” The Queen City Society for the Prevention of CRuelty to ChlldRen, AnNual Report, 1882, at 4 (Buffalo, no publisher 1882). Indeed, the society successfully lobbied in 1882 for a Buffalo city ordinance subjecting children and their parents to fines if the children were " allowed to loiter, peddle, or be engaged in any vocation on any of the streets of the city" after nine on summer evenings or eight on winter nights, "unless accompanied by or under the charge of some person of full age."' Id. at 4, 10 (quoting Buffalo city ordinance enacted on Sept. 11, 1882). The Queen City society applauded the Buffalo police for their "hearty coöperation" in enforcing this ordinance. Id. at 4. "In most instances," it elaborated, "the families of which these children were members were not in actual want." Id.

Along the same lines, the Toledo Humane Society, founded in 1884 to prevent cruelty against both children and animals, reported in its first year of operation that "the grossest cruelty" to children resulted not "from indiscriminate corporal punishment," but instead "from the fact that hundreds of [children] were being nursed in veritable hot beds of iniquity, and thus being prepared for lives of crime." First Annual Report of the Toledo Humane Society, for the Prevention of Cruelty to Animals and Children Organized, 1884, at 12 (Toledo, Comly \& Francisco 1885?). "Forcing children to beg" was, it explained, a "form of cruelty which prevail[ed] to an alarming extent" among parents who thought that "the world owed [them] a living, and [that their] children should go out and get it." Id. at 7 (original emphasis omitted). The society warned that " $[t]$ he result of this crime against society [was], generally, a house full of vagrants, thieves and vagabonds, who finally find their way into our infirmaries, refuges and jails." Id.

The California Society for the Prevention of Cruelty to Children, founded in San Francisco in 1876, was likewise devoted to "suppress[ing] the demoralizing practice of employing children, and especially young girls, to vend flowers and other articles of sale upon the public streets and in those places of business to which they can gain access-a practice that oftentimes involves results most painfully offensive to morality and paves the way to an inevitable life of shame." THE CALIFORNIA SOCIETY FOR the Prevention of Cruelty to Children, Thirteenth Annual Report for the Year Ending December 31, 1889, at 3-6 (San Francisco, Geo. Spaulding \& Co. 1890). The California society's campaign was greatly facilitated by two overlapping state statutes enacted in 1878 that subjected parents to criminal penalties and the loss of custody if their children participated in "the vocation, occupation, service, or purpose of singing, playing on musical instruments, rope or wire walking, dancing, begging, or peddling, or [performed] as a gymnast, acrobat, contortionist, or rider, in any place whatsoever" or (similarly) were found "begging, whether actually begging, or under the pretext of peddling." An Act relating to children, ch. $521, \S \S 1,3,1878$ Cal. Stat. 813,813-14; An Act for the protection of children, and to prevent and punish certain wrongs to children, ch. $520, \S \S 2-3,1878 \mathrm{Cal}$. Stat. 812, 812-13.

174. An Act to prevent and punish wrongs to Children, $\S \S 1,3,5,1877$ Ill. Laws 90, 90-91. 
Illinois Humane Society, originally dedicated solely to the protection of animals, unofficially investigated its first case of child cruelty in $1877 .{ }^{175}$

Within a few years, reformist concern in Illinois began to focus even more intently on children, particularly girls, who spent significant portions of their time on the streets, acquiring money in one way or another. Louise Rockwood Wardner, for instance, offered quite typical warnings as an Illinois delegate to the Annual Conference of Charities held in 1879, predicting that these children were destined to become "vagrants and outcasts at seven years of age, thieves at ten, ruffians at twelve, and inmates of penal institutions or houses of prostitution at fifteen or earlier." ${ }^{176}$ She concluded that child laborers had to be either orphans or children trapped with "vile, unprincipled, debauched, drunken parents, who [were] rearing them by teaching and example to a familiarity with vice." 177 Like many nineteenth-century Americans, Wardner found the prospect of girls' moral ruin particularly troubling. She advocated their institutionalization, arguing that commitment would rescue girls from their unscrupulous and unloving parents, and introduce them to the domestic arts. ${ }^{178}$

The Illinois Legislature responded to this growing reform impulse that same year, facilitating dramatic intervention into families without a father able to shield his dependents from commercial pursuits. Much like the 1877 statute, the Illinois Legislature's 1879 law provided that a girl could be removed from her parent's custody because she "frequent[ed] any street, alley or other place, for the purpose of begging or receiving alms" or "for other cause [was] a wanderer through streets and alleys, and in other public places." ${ }^{179}$ The 1879 statute, however, also provided for the incorporation of state-supervised Industrial Schools for Girls "to provide a home" for these children. ${ }^{180}$ The only evidence the statute offered to explain why the Industrial Schools would provide an

175. The society was then known as the Illinois Society for the Prevention of Cruelty to Animals. See Oscar L. Dudley, Sixteen Years' Work Among the Dependent Youth of Chicago, in History of CHILD Saving in the United States at the Twentieth National Conference of Charities and Correction in Chicago, June, 1893, at 99, 102-03 (Committee on the History of Child-Saving Work ed., Boston, Geo. H. Ellis 1893).

176. Louise Rockwood Wardner, Girls in Reformatories, in ProceEdngs of THE SIXTH ANNUAL Conference of Charties, Held at Chicago, June, 1879, at 178, 179 (F.B. Sanborn ed., Boston, A. Williams \& Co. 1879).

177. Id. at $179-80$.

178. As Wardner elaborated:

Shall we not, in taking the large number of young girls who are filling our city streets and alleys, our almshouses, and worse places, miscalled homes,- -shall we not, in protecting and sheltering them from temptation, guiding, controlling, and training them to become useful, good, independent women, and virtuous wives and mothers,--reach the very fountain from which flow the evils we desire to arrest?

Id. at 181 .

179. An Act to aid industrial schools for girls, $\S 3,1879$ IIl. Laws 309, 309-10; see also An Act to amend sections three (3), five (5) and nine (9) of an act entitled "An act to aid industrial schools for girls," approved May 28, 1879, in force July 1, 1879, § 1, 1885 Ill. Laws 243, 243 (virtually identical language).

180. An Act to aid industrial schools for girls $\S 1-2,14$. 
adequate home, where the girls' parents had not, was that the Industrial Schools would teach the girls to substitute housework - a proper female "avocation[]," done in private, and therefore not real labor at all-for commercial activity in the street. By statute, the schools were charged with instructing the girls in the "domestic avocations, such as sewing, knitting, and housekeeping in all its departments." 181

The Illinois Legislature was slower to create a parallel institutional structure for boys, but here agents of the Illinois Humane Society took the lead. The Illinois society officially included children in its jurisdiction in 1881, recognizing that child cruelty had already come to constitute two-thirds of the group's caseload. ${ }^{182}$ By 1887 , this transformed society had helped secure the equivalent statutory authorization for boys' institutions and the incorporation of the Illinois School of Agriculture and Manual Training for Boys. ${ }^{183}$

With the assistance of court-appointed counsel, a girl committed under the statute for female children challenged the law's constitutionality, on the theory that she had been imprisoned without the due process required for criminal confinement. ${ }^{184}$ But the Illinois Supreme Court accepted the State's argument that the Industrial Schools had properly appropriated the prerogatives of failed parents. The Industrial Schools, the court held, could exercise "the same power of needful restraint in the child's care and education as belonged to the parent" because the Schools were providing "for the needed control and care of female infants," where the children's parents had not. ${ }^{185}$ With the path cleared, the

181. Id. $\$ 10$.

182. The society also officially renamed itself the Illinois Humane Society in 1881 . See Dudley, supra note 175, at 104. By 1922, there were 307 humane societies in the United States that combined child and animal protection. See SHuLTZ, supra note 163, at 14.

183. See An Act to provide for and aid training schools for boys, § 3, 1883 Ill. Laws 168, 168-69; An Act to amend sections three (3), five (5) and nine (9) of "An act to provide for and aid training schools for boys," approved June 18, 1883, in force July 1, 1883, and to further amend said act by adding thereto a section to be numbered fourteen (14), $\S 1,1885$ Ill. Laws 238, 238-39; A Brief History, 16 Humane J. 39, 39 (1888); Dudley, supra note 175, at 107, 111-13; The Illinois Industrial Training School for Boys, 15 Humane J. 114, 114 (1887); Oscar L. Dudley, 17 Humane J. 25, 25 (1889). For a later Illinois statute that applied to both girls and boys, see An Act to regulate the treatment and control of dependent, neglected and delinquent children, $\$ 1,1899$ Ill. Laws 83, 83 (defining "neglected child" to include any child "who habitually begs or receives alms" and "any child under the age of 8 years who is found peddling or selling any article or singing or playing any musical instrument upon the street or giving any public entertainment").

184. See In re Ferrier, 103 Ill. 367, 369-71 (1882). Counsel for the girl relied on People v. Turner, 55 III. 280 (1870), which struck down a statute providing for the commitment of a child who "is destitute of proper parental care, or is growing up in mendicancy, ignorance, idleness or vice," id. at 282 (quoting statute). The Turner court, writing before the advent of the child cruelty movement, had found that definition of parental failure radically under-specified. See id. at 283-84 ("What is proper parental care? The best and kindest parents would differ, in the attempt to solve the question .... [T] he conclusion is forced upon us, that there is not a child in the land who could not be proved ... to be in this sad condition."). The statute at issue in Tumer also provided far fewer procedural protections than the 1879 Industrial Schools statute. See In re Ferrier, 103 Ill. at 370-71 (reviewing augmented protections under Industrial Schools statute).

185. In re Ferrier, 103 Ill. at 372; see also County of McLean v. Humphreys, 104 Ill. 378, 383-84 (1882) ("[The act only imposes restraints that] are essential to the comfort and the well-being of the 


\section{Illinois Humane Society systematically took children into custody for begging on the streets and arrested their parents. ${ }^{186}$}

\section{MOTHERS' PENSIONS}

In the first third of the twentieth century, this bifurcation in the law's treatment of parenthood began to take what would become its more prominent contemporary form. The second legal turning point examined in this Part concerns the mothers' pension laws that were enacted in twenty state legislatures between 1911 and $1913,{ }^{187}$ forty of the forty-eight states by $1920,{ }^{188}$ and every state but Georgia and South Carolina by 1935 . $^{189}$

unfortunate class of persons who are brought within its provisions. All governmental and parental care necessarily imposes more or less wholesome restraint, and we see nothing in the act which looks beyond this." (emphasis added)). The Wisconsin Supreme Court upheld a similar statute that provided for the commitment of children found "“in any public street or place for the purpose of begging," or " "found wandering in streets, alleys or public places, and belonging to that class of children called 'ragpickers."' Milwaukee Indus. Sch. v. Supervisors of Milwaukee County, 40 Wis. 328, 334 (1876) (quoting An Act authorizing industrial schools, ch. 325, § 5, 1875 Wis. Laws 632, 633). The court reasoned that the parents of these children had, by definition, "wholly failed to perform" their responsibilities, leaving the state "to assume parental authority." Id. at 338.

186. The president of the Illinois Humane Society noted in 1896 , for instance, that

there is no one here who is not more or less cognizant of the difficulties attending the treatment by this Society of child begging upon our public streets. It is a difficult matter to control. The youngsters know our officers so well that, when they appear in sight, these little vagrants will scuttle away, like so many rats, into hiding places and escape. They are all perfectly well aware they are doing that which is contrary to law. We are also made conscious of the difficulty of convicting these little children before our magistrates, who temper justice with mercy-sometimes, as we think, too much mercy-in the little ones' behalf; but we have been successful in several cases in bringing the parents, who are really responsible for this species of cruelty, to book.

Twenty-Seventh Annual Report of the Illinots Humane Society 8 (Chicago, Illinois Humane Society 1896); see also id. at 8-9 (recording the arrest of eight parents whose children the Illinois Humane Society caught begging in the streets).

187. Missouri passed the first mothers' pension law in 1911, but the statute was limited to one county. See An Act to provide for the partial support of poor women, whose husbands are dead or convicts, when such women are mothers of children under the age of fourteen (14) years and reside in counties now or hereafter having not less than two hundred and fifty thousand $(250,000)$ inhabitants and not more than five hundred thousand $(500,000)$ inhabitants, and now or hereafter having or holding a juvenile court, with an emergency clause, $1911 \mathrm{Mo}$. Laws 120. That same year, Illinois passed the first state-wide statute. See An Act to amend an Act entitled, "An Act relating to children who are now or may hereafter become dependent, neglected or delinquent, to define these terms, and to provide for the treatment, control, maintenance, adoption and guardianship of the person of such children," 1911 Ill. Laws 126. It was followed in 1913 by California, Colorado, Idaho, Iowa, Massachusetts, Michigan, Minnesota, Nebraska, New Hampshire, New Jersey, Nevada, Ohio, Oregon, Pennsylvania, South Dakota, Utah, Washington, and Wisconsin. See Theda Skocpol, Protecting Soldiers and Mothers: The Political Origins of Soclal Policy in the United States 446 tbl.9 (1992); Mark H. Leff, Consensus for Reform: The Mothers'-Pension Movement in the Progressive Era, 47 Soc. SERv. REv. 397, 401 tbl.1 (1973).

188. By the end of 1920, only Alabama, Georgia, Kentucky, Mississippi, New Mexico, North Carolina, Rhode Island, and South Carolina had not enacted a mothers' pension law. See SкocPol, supra note 187 , at 447 tbl.9; Leff, supra note 187 , at 401 tbl.1.

189. See SkocPol, supra note 187, at 447 tbl.9; Leff, supra note 187 , at 401 tbl.1. For discussions of the activist coalition that helped spur the rapid passage of the mothers' pension laws, see LINDA 
The mothers' pension laws, which authorized local governments to provide direct financial support to poor mothers, ${ }^{190}$ differed from the child cruelty societies in two important institutional respects that would also come to typify later legal regulation. First, these statutes established completely governmental programs, which were not dependent on enforcement by private reformers imbued with public powers. Second, and more crucially, these laws primarily accomplished their aims through the provision and refusal of much needed financial aid, building on a growing consensus among reformers of the period that this strategy was both more effective, ${ }^{191}$ and more cost-efficient, ${ }^{192}$ than removing children from their parents' custody. The legal regimes that eventually

Gordon, Pitied but Not Enttrled: Single Mothers and the History of Welfare, 1890-1935, at 38 (1994); SKoCPOL, supra note 187, at 464-65; and Leff, supra note 187 , at 405-13.

190. It is important to note that nearly all of the mothers' pension statutes permitted, rather than required, local government authorities to distribute aid. Jane M. Hoey, the director of the federal Bureau of Public Assistance, later estimated that "about 75 per cent of all the children receiving [mothers'] aid in 1934 lived in nine states. By 1935, probably less than one-half the counties with legal authority to grant mothers' aid were actually providing it." Jane M. Hoey, Aid to Families with Dependent Children, 202 Annals Am. ACAD. Pol. \& Soc. Sci. 74, 74 (1939). In 1921 and 1922, a reported 45,825 families were receiving mothers' pension grants. By 1931, the number had reached 93,620 families. See Children's Bureau, U.S. Dep'T of Labor, Pub. No. 220, Mothers' Aid, 1931, at 8 tbl.1 (1933).

191. By the turn of the century, many reformers had growing suspicions about the efficacy of child care institutions. See, e.g., Mary Conyngton, How to Help: A Manual of Practical Chartiy 186 (1909) ("If the mother is a fit person to have the custody of her children, poverty is not a valid reason for [separation] .... An institution, no matter how good, is a poor place for a child. Even a very poor home offers a better chance for its development ... ."); Charles H. Baker, Arguments in Favor of Public Outdoor Relief, in Proceedings of the National Conference of Chartites and Correction at the Eighteenth Annual Session Held in Indianapolis, Ind., May 13-20, 1891, at 31, 32 (Isabel C. Bartows ed., Boston, Geo. H. Ellis 1891) ("The feeling of kinship begotten in a home, however lowly, if it be a home of virtue, has an influence to lift us in the scale of being, which feeling and influence are not known, and cannot be known, in a normal sense, under the public roof."); E.E. Porterfield, How the Widow's Allowance Operates, 7 Child-Welfare MAG. 208, 208 (1913) ("A good mother can rear her children better than the best institution. A mediocre home is better than any institution. A child reared in any institution is more or less a human machine. The best citizens come from the home in which the influence of the mother is felt.").

192. See, e.g., Address by Rabbi Emil G. Hirsch, D.D., LL.D., PH.D., President National Conference of Jewish Charities, of Chicago, Ill., Delivered at the Conference Held in Washington, January 25 and 26, Called on Request of the President, in Proceedings of THE CONFERENCE on THE CARE OF DePENDENT Children Held at Washington, D.C. January 25, 26, 1909, S. Doc. No. 60-721, at 85, 90 (1909) ("In the long run, pensioning mothers is cheaper than building almshouses and jails and reformatories."); Remarks of Mr. Max Mitchell, of Boston, Mass., Superintendent Federated Jewish Charities, in Proceedings of the Conference on the Care of Dependent Children Held at Washington, D.C. JANUARY 25, 26, 1909, supra, at 49, 49-50 ("Instead of breaking up a home and paying for the board of her children in a private family, ... . let the amount involved be paid to the mother in the exercise of her own trade, which she already knows-a mother's trade-the bringing up of her children .....'); Ada J. Davis, The Evolution of the Institution of Mothers' Pensions in the United States, 35 AM. J. SoC. 573, 582 (1930) (explaining that mothers' pensions were supposed to function "without any increased burden on the taxpayer," the idea being that they would "cost considerably less than the institutional care of the child" and also "make it possible for the child to have the protective care and attention of the mother in the home"); Helen Todd Says Support Mothers, Womas's J., Jan. 9, 1915, at 14, 14 ("It needs a woman's sense to see the cruelty and folly of breaking up widowed homes. It costs more in the first place, and in the second, it kills child life and normal human development. It is good economy to help the mother to keep her home together . ..."' (quoting Helen Todd)). 
superseded the mothers' pension laws would make the same choice, and operate largely through the grant and denial of aid or benefits, rather than the grant and denial of custody.

A number of scholars, focusing on these structural innovations, have described the mothers' pension laws as a groundbreaking change in the legal regulation of the poor. ${ }^{193}$ And, indeed, the advocates of mothers' pension laws did express a commitment to honoring and rewarding the labor and contributions of needy mothers that was not nearly as visible in the work of the child cruelty societies. ${ }^{194}$ Yet the fundamental norms and presumptions that governed the actual operation of the mothers' pension programs carried over from the nineteenth century. The mothers' pension programs, like the cruelty societies before them, ran on the guiding principle that a father's failure to fully provide for his wife and children was grounds for subjecting both the failed father and the woman and children who were or should have been attached to him to legal rules wholly unlike those conventionally associated with family law.

Family law, as it was authoritatively defined in the early twentieth century, continued to be committed to the staunch protection of parental judgment and autonomy. The common law doctrine guarding a parent's right of correction, for instance, did not change noticeably from the late nineteenth to the early twentieth century. ${ }^{195}$ Indeed, the early twentieth century was marked by two

193. See 2 Grace Abbott, The Child and the State 229 (1938) (“[The mothers' pension laws] represented a revolt against the current policy of separating children from their mothers on the ground of poverty alone and caring for them at greater cost in institutions and foster-homes."); GoRDON, supra note 189 , at 38 ("The inadequacy of mothers' aid should not mask its historical significance as a welfare accomplishment. Breaking with laissez-faire and Social Darwinist assumptions, it not only asserted a public responsibility for the poor but also sought to remove relief from the stigma of pauperism and the poorhouse."); id. at 38-39 ("[Mothers' aid] offered, moreover, a feminist version of those principles, honoring the quintessential female labor, mothering .... Mothers' aid was a kind of child custody reform for the poor."); Michael B. Katz, In the Shadow of the Poorhouse: A Social History of Welfare IN AMERICA 124 (1986) ("By the early 1890s, child-saving strategies had changed radically ... . [M]ost reformers ... rejected the notion that children should be taken from their families simply on account of poverty.... This emphasis on family preservation reflected a major shift in reform thought .... Once family breakup was rejected, ... mothers' pensions had to follow.").

194. See, e.g., Helen Todd Says Support Mothers, supra note 192, at 14 ("“[I]t is preposterous that we should be willing to pension veterans for having blown the lives out of people and not pension women for putting life into people."' (quoting Helen Todd)); Our Christmas Wish for Women: That Every Decent Mother in America Could Have Her Babies With Her, DeLineAToR, Dec. 1912, at 413, 413 ("Set the children free! Let them go back to their mothers! And let the mothers earn their living from the State by doing the most useful thing they could possibly do-bring up their children!'); Mary Wood, The Legal Side of Industrial Betterment, in THE General Federation of Women's Clubs Eleventh Biennial Convention June 25 to July 5, 1912, San Francisco, Cal. Official Report 183, 185 (Mrs. George O. Welch ed., 1912) ("[W]idows [with 'small children'] should receive from the state, a pension sufficient to enable each to look after children and home.... The woman who produces citizens and soldiers should be placed in a class with the disabled soldier, during the period she is unable to earn for herself and children.").

195. See 1 Joel Prentiss Bishop, Bishop on Criminal Law 627 (John M. Zane \& Carl Zollmann eds., 9th ed. 1923) ("[I]f [a parent] acts in good faith, prompted by true parental love, without passion, and inflicts no permanent injury on the child, he should not be punished merely because a jury reviewing the case dissents from his judgment therein."); JAMES Schouler, LAW OF THE DOMESTIC Relations 
celebrated Supreme Court cases, Meyer v. Nebraska (1923) ${ }^{196}$ and Pierce v. Society of Sisters (1925), ${ }^{197}$ that importantly constitutionalized common law principles of deference to parental control and decision making. Meyer struck down a state statute that prohibited schools from teaching foreign languages to young children, holding that it unreasonably infringed upon a parent's right under the Due Process Clause of the Fourteenth Amendment to "establish a home and bring up children." 198 Pierce similarly held that a state law requiring parents to send their children to public, rather than private, schools was unconstitutional under the Due Process Clause because it "unreasonably interfere[d] with the liberty of parents and guardians to direct the upbringing and education of children under their control." ${ }^{199}$ Both decisions were grounded in the judgment that "[t]he child is not the mere creature of the State; those who nurture him and direct his destiny have the right, coupled with the high duty, to recognize and prepare him for additional obligations." ${ }^{200}$ In many arenas in the early twentieth century, in other words, the norms and presumptions conventionally associated with family law were endorsed, perpetuated, and sometimes even given constitutional backing. The application of common law principles of deference to parental judgment and autonomy was understood to be both appropriate and constitutionally required, for instance, where parents able to afford private schooling for their children were at issue. The mothers' pension programs, like their nineteenth-century predecessors, operated on the conviction that new and different bodies of law, shaped by much more interventionist, instrumental, and suspicious principles, needed to govern families in which the father, if alive, was unsuccessful in the wage labor economy, and his dependents required economic support from the public.

First, and perhaps more than anything else, the laws governing the mothers' pension programs were driven by an intense suspicion of fathers who were not supporting their families on their own. Much like the cruelty societies, the authors of the mothers' pension laws were certain that a family's poverty generally reflected a father's sloth or moral degeneracy, and they were determined to create no incentive toward either type of vice. The statutes absolutely excluded needy families that had a healthy father living with them, on the ground that these fathers were totally responsible for their family's own maintenance and had no legitimate reason for their failure. ${ }^{201}$ The mothers' pension programs also all but excluded families of color, understood to be particularly

$240 \mathrm{n} .1$ (1905) ("The law reluctantly interferes criminally in such cases unless the parental chastisement produces permanent injury or was maliciously inflicted.").

196. 262 U.S. 390 (1923).

197. 268 U.S. $510(1925)$.

198. Meyer, 262 U.S. at $397,399-400$.

199. Pierce, 268 U.S. at 530-31, 534-35.

200. Id. at 535 .

201. See infra text accompanying notes 206-11. 
prone to indolent reliance on the public. ${ }^{202}$ The only thorough study of the racial distribution of mothers' pensions found that ninety-six percent of the families receiving them in 1931 were white, as compared to just three percent who were African-American, and one percent who "belonged to other races." ${ }^{203}$ Discrimination was most intense in the South, ${ }^{204}$ but approximately half of all the black families identified as collecting mothers' pensions in 1931 lived in just two states: either Ohio or Pennsylvania. ${ }^{205}$

Even when a (white) father was absent or incapacitated, the mothers' pension laws still evaluated women and children in terms of judgments about the men who should have been supporting them but were not. Indeed, women's claims to pensions turned to a remarkable extent on assessments of men who were no longer there. Gendered norms about the way in which domesticity was sup-

202. See First Biennial Report of the Department of Social Welfare of the State of California, 1927-28, at 55 (1929) ("From its experience the Outdoor Relief [Department of the Los Angeles County Charities] believes that the feudal background of the Mexican makes it difficult, if not well nigh impossible, for him to understand and not abuse the principle of a regular grant of money from the state."); Mary Odem, Single Mothers, Delinquent Daughters, and the Juvenile Court in Early 20th Century Los Angeles, 25 J. Soc. Hist. 27, 29 (1991) ("In addition to the formal eligibility requirements established by the state, the Los Angeles County Outdoor Relief Department, which was responsible for processing county applications for aid, adopted a policy of refusing mothers' pensions to Mexican widows. County officials claimed that Mexican immigrants had a dangerous propensity for 'leaning' on the state.").

203. ChILdRen's Bureau, supra note 190, at 13.

204. See id. at 26-27. Almost all the mothers' pension statutes were facially neutral on questions of race. See White House Conference on Child Health and Protection, Dependent and Neglected ChILdRen: Report of the Committee on Socially Handicapped-Dependency and Neglect 301 (1933) ("The only statute relating to mothers' aid mentioning race or color as a factor conditioning the grant is found in Alaska."). But the South, the area of the country where the overwhelming majority of African-Americans lived in this period, was also the region to most aggressively pursue two different practical strategies for keeping black families off the mothers' pension rolls. First, some southern states simply delayed enacting mothers' pension laws, and then funded mothers' pension programs in only a limited number of counties. See id. at 301-02; supra notes 187-89 and accompanying text. Second, the mothers' pension programs that did exist in the South gave local administrators enormous authority, which they exercised by systematically excluding applicants who were not white. Between 1924 and 1926, for instance, approximately $29 \%$ of the population of North Carolina was African-American, but African-Americans received only $4(1.63 \%)$ of the 246 mothers' pensions that the state provided. See White house Conference on Child Health and Protection, supra, at 302. Similarly, only two African-American families were known to have ever received a mothers' pension in Florida. See id.

205. See Children's Bureau, supra note 190, at 13; see also Joanne L. Goodwin, An American Experiment in Paid Motherhood: The Implementation of Mothers' Pensions in Early Twentieth-Century Chicago, 4 GENDER \& Hist. 323, 336 tbl.1 (1992) (reporting that African-Americans constituted two percent of the Chicago population in 1911 and six percent of the poor relief rolls, but they received no mothers' pensions; in 1920, African-Americans constituted four percent of the Chicago population and eight percent of the poor relief rolls, and received three percent of the mothers' pensions); CHLDREN's Bureau, U.S. Dep't of Labor, Pub. No. 109, Proceedings of Conference on Mothers' Pensions 2, 4 (1922) ("[Q]uestionnaires were sent in February to 125 mothers' allowance and other public agencies throughout the country, and we have received 45 well-considered replies.... Eleven [of these 45] agencies made deviations from the [budget] schedule on account of nationality. One agency had a Mexican problem which affected the use of the schedule. Another agency figured a low estimate for food and clothing for foreign families. A third agency granted lower allowances for Italian and Czechoslovakian families."). 
posed to be organized were so inscribed in the mothers' pension laws that mothers with precisely the same need for aid were treated very differently based on their relationships with men, notwithstanding the fact that most of the women eligible for mothers' pensions were not in those relationships anymore.

Within (white) families with only a mother present, the mothers' pension laws (which were sometimes called widows' pension laws) favored the widowed over the deserted, the deserted over the divorced, and the divorced over the never married. Marital status served as a proxy for the mother's sexual morality, with widowhood at the virtuous end of the spectrum and unmarried motherhood at the other. But it was also used to identify those few families that might have an acceptable explanation for being without a father's steady financial support. In a program without an understanding of the structural sources of poverty, widows had the best excuse for their financial need. As the New York State Commission on Relief for Widowed Mothers explained, "the misfortune that follows upon the decease of the poorer laborer is not caused in any way by those who must suffer."206 Moreover, providing relief to widows could not "in any way increase the number of worthy families in distress," while "[t]o pension desertion or illegitimacy would, undoubtedly, have the effect of a premium upon these crimes against society." ${ }^{207}$ Where every mothers' pension statute included widows, just three states by 1931 explicitly covered mothers who had never married and just ten more states covered them implicitly. ${ }^{208}$ Deserted mothers, in turn, were eligible in thirty-five out of forty-five states and divorced mothers in twenty-one. ${ }^{209}$ Local administrators, moreover, privileged widows more intently than even the statutory provisions suggest. Nationwide in $1931,82 \%$ of the mothers receiving mothers' pensions were widows. ${ }^{210}$ Mothers who had never married were explicitly eligible for aid in Michigan, but only $25(1.25 \%)$ of the 2000 mothers' pension recipients in a 1933-1934 study actually fell into that category, as compared to $1226(61.30 \%)$ widows, 325 (16.25\%) deserted wives, 175 (8.75\%) divorced wives, 151 (7.55\%) wives with a physically or mentally incapacitated husband, and $98(4.90 \%)$ wives with a husband in prison. ${ }^{211}$

206. State of New York, Report of the New York State Commission on Relief for Widowed MOTHERS 21 (1914).

207. Id.

208. See Children's Bureau, supra note 190, at 3. Michigan, Nebraska, and Tennessee were the three states that explicitly included mothers who had never been married. See id. at 3 n. 11 .

209. Twenty-five states specifically included deserted mothers, and eleven states specifically included divorced mothers. Ten additional states implicitly included both categories. See id. at 3 . Thirty-seven states (twenty-seven explicitly) included mothers whose husbands were imprisoned. Forty-three states (thirty-three explicitly) included mothers whose husbands were physically or mentally incapacitated, although five of those states required that the husband be living in an institution. See id.

210. See id. at 11 (also noting that $5 \%$ of the mothers had been deserted, $4 \%$ were married to a man who was physically disabled, $3 \%$ were married to a man who was mentally disabled, another $3 \%$ were married to a man who was imprisoned, and $2 \%$ were divorced).

211. See Reba F. Harris, Michigan State Welfare DeP't, Mothers' Aid in Michigan: A Report of STATE-WIDE STUdY 3-5 (1934); see also id. at 4 ("In 21 counties certain types of cases were refused aid 
The mothers' pension laws reflected a consuming dissatisfaction with fathers who had failed to support their wives and children, and a willingness to express this antipathy by penalizing the women and children associated with the unsuccessful family men. In addition, however, the mothers' pension laws directed almost as much suspicion at the mothers who needed public aid because they had no husband able to support their family. The statutes took the fact that these women had turned to the state for economic assistance as grounds for questioning their fitness for motherhood, scrutinizing their behavior, and regulating their relationships with their children. Virtually every mothers' pension law included a provision limiting the program to mothers who were "physically, mentally and morally fit." 212 The exact characteristics needed to satisfy those criteria were usually left unspecified to maximize the discretion of the local administrators who determined eligibility and conducted home visits to monitor continued compliance. ${ }^{213}$ But the concern with fitness reflected the fact that this popula-

by the Judges of Probate although the law does not grant him such power. For example-in 17 counties the children of divorced or unmarried mothers are not allowed Mothers' Aid.").

212. See, e.g., Aid to Mothers and Children-Act of 1913 Amended, § 11(4), 1915 III. Laws 243, 244 ("[S]uch mother must, in the judgment of the court, be a proper person, physically, mentally and morally fit, to have the care and custody of her children."). By the start of 1929 , only Arizona, California, Connecticut, New Jersey, and Texas did not include substantially similar language in their mothers' pension statutes. Connecticut and Texas, however, explicitly limited their mothers' pension programs to widows, and New Jersey included only widows and women raising orphans. See $\mathrm{CHLL}_{\mathrm{HL}}$ dren's Bureau, U.S. Dep't of Labor, Chart No. 3, A Tabular Summary of State Laws Relating to Public Aid to Chlldren in Their Own Homes in Effect January 1, 1929 and the Text of the Laws of Certain States 4-25 (3d ed. 1929).

213. Recipients of mothers' pensions in Illinois, for instance, were "subject to the friendly visitation of a probation officer." An Act to amend an Act entitled, "An Act relating to children who are now or may hereafter become dependent, neglected or delinquent, to define these terms, and to provide for the treatment, control, maintenance, adoption and guardianship of the person of such children," $\$ 1,1911$ IIl. Laws 126, 126. In the first 11 months of the Illinois program, 17 out of 306 families lost their grants for such reasons "as the death of the mother, or her conceded unfitness from causes and conditions arising subsequent to the order for relief." Merritt W. Pinckney, Public Pensions to Widows: Experiences and Observations Which Lead Me to Favor Such a Law, in Proceedings of the National Conference of Charities and Correction at the Thirty-Ninth Annual Session Held in Cleveland, OhIo JUNe 12-19, 1912, at 473, 476 (Alexander Johnson ed., 1912). For examples of other mothers' pension statutes requiring home visits, see An Act To provide home care for dependent children in the District of Columbia, ch. 647, $\S 5,44$ Stat. pt. 2, at 758, 759 (1926) (requiring a mothers' pension administrator to visit "every home for which an allowance is made" as often as "necessary to observe the conditions which obtain in the home, the care which the child is receiving, and to offer such friendly counsel and advice as may be helpful to the mother and the child"); and An Act to provide for suitably aiding mothers with dependent children, ch. 763, § 3, 1913 Mass. Acts 726, 727-28 (requiring mothers' pension administrators to visit the home of each recipient family "at least once in every three months," in order to report on "the condition of the home and family" and decide whether to continue aid).

During home visits, administrators commonly looked for signs of extramarital sexuality, alcoholic beverages, or sloppy housekeeping. See Mary F. Bogue, Children's Bureau, U.S. Dep't of Labor, Pub. No. 184, Administration of Mothers' Aid in Ten Localities with Special Reference to Health, Housing, Education, and ReCreation 29, 40 (1928) (reporting that mothers' pension administrators in Allegheny County, Pennsylvania conducted home visits "at least once a month" to make sure, inter alia, that recipients were not keeping any "men boarders or lodgers other than [a] brother or father"); THIRD Annual Report of the Board of Child Welfare of the City of New York, January 1, 1918 to DECEMBER 31, 1918, at 18 (1919) (explaining that the board would not grant or continue a mothers' 
tion of mothers was considered a potential threat to both individual children and the nation at large. Influential Americans in this era, as in the late nineteenth century, increasingly believed that the fate of the United States depended on the eugenic composition of the country's population and understood vast numbers of their fellow citizens to be irredeemably inferior. A majority of states in the late nineteenth and early twentieth centuries, for instance, passed laws prohibiting the marriage of the "feebleminded," 214 a condition that was variously defined but taken to be inheritable. ${ }^{215}$ The mothers who applied for mothers' pensions were frequently foreign-born, reflecting immigrants' disproportionate share of poverty. ${ }^{216} \mathrm{By}$ the dominant logic of the day, that alone identified them as predisposed to "inborn socially inadequate qualities" that threatened the nation's survival. ${ }^{217}$ But poverty itself was also generally taken to be excellent evidence of eugenic unfitness and feeblemindedness. ${ }^{218}$ So was female sexual

pension if the mother was "mentally, morally [or] physically" unfit; if she had "a record of intemperance, wastefulness, or of misconduct;" if "the presence and behavior of lodgers are such as to bring the widow into disrepute;" or if "the home and the children are not kept clean and orderly, or are otherwise neglected, or where the children are unnecessarily kept from school or from work").

214. See Matthew J. Lindsay, Reproducing a Fit Citizenry: Dependency, Eugenics, and the Law of Marriage in the United States, 1860-1920, 23 L. \& SoC. INQuIRY 541, 542 (1998) ("The Connecticut legislature led the way in 1895 , prohibiting 'feebleminded, imbecilic, and epileptic men and women under 45 years of age' from marrying. Similar legislation was then adopted throughout the nation. By 1929, 29 states barred 'imbeciles,' 'idiots,' 'lunatics,' the 'feebleminded,' and those of 'unsound mind' from marriage." (citations omitted)).

215. See Charles Benedict Davenport, Heredity in Relation to Eugenics 67 (1911) ("In view of the certainty that all of the children of two feeble-minded parents will be defective how great is the folly, yes, the crime, of letting two such persons marry."); Thurman B. Rice, Racial Hygiene: A Practical Discussion of Eugenics and Race Culture 133 (1929) ("Its inheritance is well understood. Feeble-mindedness is a recessive condition, a condition due to the lack of some normal determiner. It is for this reason that practically all of the children of two hereditarily feeble-minded parents are feeble-minded.... Under no circumstances should a feeble-minded person be permitted to bear children.").

216. For instance, German immigrants in Chicago constituted seven percent of the city population in 1911, and eleven percent of the poor relief rolls. They received twenty percent of the mothers' pensions. Irish immigrants constituted three percent of the population, accounted for ten percent of the relief rolls, and received twenty-two percent of the pensions. Italian immigrants constituted two percent of the population, accounted for eight percent of the relief rolls, and received eight percent of the pensions. Polish immigrants constituted six percent of the population, accounted for nineteen percent of the relief rolls, and received fourteen percent of the pensions. See Goodwin, supra note 205, at 336 tbl.1.

217. Analysis of America's Modern Melting Pot: Hearings Before the House Comm. on Immigration and Naturalization, 67th Cong. 755 (1923) (statement of Dr. Harry H. Laughlin, Eugenics Record Office, Carnegie Institution) ("The outstanding conclusion is that, making all logical allowances for environmental conditions, which may be unfavorable to the immigrant, the recent immigrants, as a whole, present a higher percentage of inborn socially inadequate qualities than do the older stocks."); see also DAVENPORT, supra note 215 , at 219 ("[U]nless conditions change . . , the population of the United States will, on account of the great influx of blood from South-eastern Europe, rapidly become darker in pigmentation, smaller in stature, more mercurial, more attached to music and art, more given to crimes of larceny, kidnapping, assault, murder, rape and sex-immorality...."); J.B. Peabody, Putting It Up to Philanthropy, 29 SuRver 98, 99 (1912) ("Instead of decreasing our own unfit classes, we go on adding to them by admitting every year thousands of unfit immigrants.").

218. See DAVENPORT, supra note 215 , at 80 ("Barring a few highly exceptional conditions poverty means relative inefficiency and this in turn usually means mental inferiority."); VICTORIA C. WOODHULL 
immorality, a charge to which women living without a husband would always be more vulnerable. ${ }^{219}$

Even if a mother managed to prove her basic fitness despite the presumptions against her, the mothers' pension laws still sought to closely control her interactions with her children. Indeed, where the common law and its codifications systematically deferred to a parent's judgment and authority, the suspicion of mothers receiving mothers' pensions was so intense that the programs operated to defeat their own stated goals, and often placed women in near impossible situations. For example, mothers' pension statutes and local administrators routinely required mothers to spend the vast majority of their time at home with their children, without providing them with adequate funds to do so. The policies demanding a mother's presence reflected the conviction that children needed constant supervision of a sort that recipients of mothers' pensions could not be trusted to provide if the issue was left to their own judgment. Sophonisba Breckinridge, a prominent supporter of mothers' pensions, explained the need for a mother's constant presence at home in language that echoed dozens of cruelty society reports, reasoning that this sort of vigilance was necessary to keep children away from "that life of the street which is at once so alluring and demoralizing." ${ }^{220}$ But, at the same time, mothers' pension grants tended to be paltry, because the programs were chronically underfunded and states were desperately afraid of encouraging fathers to abandon their families or wives to leave their husbands. ${ }^{221}$ In fact, the grants were so

Martin, The RaPid Multiplication of THE UNFIT 38 (New York, no publisher 1891) ("The best minds of to-day have accepted the fact that if superior people are desired, they must be bred; and if imbeciles, criminals, paupers, and [the] otherwise unfit are undesirable citizens they must not be bred."); RICE, supra note 215 , at 138-39 ("The term 'pauper' is often misused. In this place it is used to designate an individual who does not wish or try to earn his living,--one who is perfectly content to accept charity indefinitely. Feeble-minded persons are often of this type ....").

219. See 15 S. Doc. No. 61-645, at 67 (1911) ("There is a growing recognition of the fact that there are many women and girls who are too defective mentally to be safe in the outside world, and who, if left unrestrained, will inevitably become mothers of illegitimate children.”); STUART Alfred QuEEN \& Delbert Martin ManN, Social Pathology 163-64 (1925) ("Feeblemindedness and mental imbalance doubtless greatly increase the probability of an irregular sex life, involving, as they do, lack of foresight, weakened powers of inhibition and tendency to yield to the impulse of the moment."); RiCE, supra note 215 , at 291 ("The problem of prostitution is to a very large extent the problem of the defective girl.... In the light of the Binet test findings, the woman of scarlet is usually found to be a foolish child who needs the care and the protection of the more fortunate members of society."); Many Favor School for Feeble-Minded, Providence DaILY J., Feb. 22, 1907, at 10 ("'Feeble-minded women who are loose in the community are often notoriously loose in another sense. It is as one would expect since there is always a marked impairment and sometimes a complete atrophy of the moral sense in feeble-minded persons." (quoting Dr. G.A. Blumer)).

220. Sophonisba Preston Breckinridge, Neglected Widowhood in the Juvenile Court, 16 Aм. J. Soc. 53,60 (1910).

221. The maximum monthly pension varied between states. For instance, New Jersey's maximum allowance in 1914 was " $\$ 9$ a month for one child, $\$ 14$ for two children, and $\$ 4$ for each additional child." Illinois offered up to " $\$ 15$ for one child and $\$ 10$ for each additional child . . (not to exceed in all $\$ 50$ for any one family)." Children's Bureau, U.S. Dep’t of Labor, Pub. No. 7, Laws Relating to "Mothers' Pensions" in the United States, Denmark and New Zealand 10 (1914). Northern industrial 
small that mothers' pension statutes and regulations explicitly contemplated that mothers, and often even their older children as well, would earn additional money elsewhere. The mothers' pension law that Illinois enacted in 1915, for instance, included detailed guidelines covering the wage work of mothers' pension recipients. ${ }^{222}$ Mothers' pension administrators in Chicago, moreover, held that any healthy child in a recipient family who was "legally old enough to work" because at least fourteen years old had to "be counted a wage earner" and "contribute his share to the family income." ${ }^{, 23}$ As a result of these crosscutting impulses, each driven by distrust for mothers who had called on the state for economic aid, mothers' pension laws and administrators pushed mothers into jobs like home laundry or piecework, among the most time-consuming and least lucrative forms of labor. ${ }^{224}$

states tended to be more generous than southern and western agricultural states. In June 1931, the average monthly grant per family varied from $\$ 69.31$ in Massachusetts and $\$ 55.09$ in Rhode Island, to $\$ 7.29$ in Oklahoma and $\$ 4.33$ in Arkansas. See CHILdRen's Bureau, supra note 190, at 17 ; see also supra text accompanying notes $206-07$.

222. See Aid to Mothers and Children-Act of 1913 Amended, § 11(3), 1915 Ill. Laws 243, 244. A 1923 study of 942 mothers' pension recipients living in nine locations found that $52 \%$ were earning money, with the proportions ranging "from 21 per cent in Boston and Haverhill [Massachusetts] to 67 and 69 per cent in Denver [Colorado] and Westchester County [New York]." Florence NesBrtT, Children's Bureau, U.S. Dep't of Labor, Pub. No. 118, Standards of Public Aid to Children in Their Own Homes 2, 17 (1923); see also Research Section, Federal Emergency Relief Administration, Research Bull. No. D-6, An Analysis of the "Unemployable” Families and Non-Family Persons on URBan Relief Rolls, December 1934, at 2 (1935) ("That most of the female heads now on [mothers' pension] relief still consider themselves in the labor market is evidenced by the fact that about 60 percent of them reported that they were working or seeking work.").

223. "A normally strong child in a pensioned family in Chicago [was] allowed to remain in school after he [was] 14 only on condition that the amount he would contribute to the family income [was] forthcoming from some other source." Edith Abbott \& Sophonisba P. Breckinridge, Children's Bureau, U.S. Dep't of Labor, Pub. No. 82, The Administration of The Aid-to-Mothers Law IN Illinols 157 (1921); see also Third Annual Report of THE BoARd of ChILd Welfare of the CITY of New York, JANUARY 1, 1918 to DeCEMBer 31, 1918, supra note 213, at 18-19 (providing that mothers' pensions would "not be granted or continued" "[t]o families where, without valid excuse, the children of working age fail to contribute adequately towards the support of the home").

224. Illinois, for instance, stated that its mothers' pension program was designed to keep a mother from "work[ing] regularly away from her home and children." Aid to Mothers and Children-Act of 1913 Amended $\S 11(3)$. If a recipient wanted to work outside the home, the state required her to secure a court order approving her work schedule and confirming that "such work [could] be done by her without the sacrifice of health or the neglect of home and children." Id. The director of the Rhode Island Mothers' Aid Bureau similarly reported in 1925 that every mothers' pension applicant who was found to be "away from her home all day at work in a mill or factory" was "advised to give up this work and return to the job of caring for and training her own children. Other work of a less confining nature such as jewelry work at home, sewing, cleaning by the hour, and part-time work in lunch-rooms was secured for these mothers." Bureau of Mothers' Aid, State of Rhode Island and Providence Plantations, Second annual Report of the State Public Welfare Commission to the General Assembly at Its JANUARY SESSION, 1925, at 6 (1925); see also HARRIS, supra note 211, at 14 ("[Mothers' pension recipients in Michigan have] the impression that if [they go] outside of the home to work even for a short time the grants will be discontinued .... Our records show that in most counties this fear is based on actual facts ...."). Denver, Colorado, Minneapolis, Minnesota, and some counties in Pennsylvania limited mothers receiving pensions to three days a week of work outside the home. See NESBIT, supra note 222, at 2, 19. In 1917 and 1918, Mary F. Bogue, the acting supervisor of the Mothers' Assistance 


\section{The Modern Divide in the Legal Regulation of Parenthood}

The bifurcation in the legal treatment of parenthood has persisted since the era of the mothers' pensions. The law of parenthood, as it is authoritatively understood, remains deferential to parental judgment and strongly predisposed against intervention. But it continues to be the case that the law takes the provision of financial support through certain government programs associated with failed fatherhood and dependency as grounds for subjecting entire families to rules and norms that are interventionist, instrumental, and wholly at odds with those conventionally identified with the law of parental relations.

To some extent, this divide in the legal regulation of parenthood has escaped critical analysis precisely because family law is still generally and officially defined to encompass only those rules and presumptions that apply to families regarded as economically self-reliant. But more fundamentally, the near impossibility under current constitutional law of raising a successful legal challenge to the bifurcation has contributed to the collapse of substantive political and popular debate about whether particular transfers of economic assistance should be cause for a complete reversal of the legal rules governing parent and child.

The present constitutional framework upholds the bifurcation in the law's treatment of parental relations as a matter of law and accepts it as a matter of common sense. In reasoning about the divide in the law of parenthood, this jurisprudence has simply adopted the perspective of the bifurcation's creators. The dual regime is understood to raise few questions and require little examination, even though many of the reasons historically offered to establish, explain, and defend the bifurcation would be rejected by large numbers of modern Americans as unconvincing and illegitimate. It is long past time for sustained reflection about whether and why the law should continue to perpetuate the divide in the regulation of parenthood.

\section{A. THE ENDURING BIFURCATION}

The divide in the legal treatment of parenthood, already structurally clear by the time of the mothers' pensions, was only solidified with the advent of the New Deal. The mothers' pension laws themselves were soon superseded by other programs that provided financial support to poor mothers. As part of the Social Security Act of 1935, the federal government established Aid to Dependent Children (ADC)-renamed Aid to Families with Dependent Children (AFDC) in 1962-which appropriated federal matching funds to state programs

Fund in Harrisburg, Pennsylvania, visited 166 mothers' pension recipients in twelve rural Pennsylvania counties. See Mary F. Bogue, Problems in the Administration of Mothers' Aid, in Proceedings OF THE National Conference of Social Work at the Forty-Fifth Annual Session Held in Kansas City, Missouri MAY 15-22, 1918, at 349, 352-53 (1919). She found that three-fourths of the women were earning wages, but "over one-half of those earning were doing day's work or washing in their own homes or both." Id. at 354 . 
that satisfied federal conditions. ${ }^{25}$ In 1996, Congress replaced AFDC with Temporary Assistance for Needy Families (TANF), also funded jointly by the federal government and the states. ${ }^{226}$

$\mathrm{ADC}$ was enacted quickly and relatively uncontroversially. It was generally understood to be simply an extension of the mothers' pension programs that the vast majority of states had already authorized. ${ }^{227}$ As a result, it attracted remarkably little attention from either critics or supporters of the New Deal, although southern congressmen did make sure that state and local ADC agencies were free to employ a wide variety of strategies to exclude AfricanAmericans from the rolls. ${ }^{228}$ The enactment of TANF, in contrast, was highly contested, characterized by advocates and opponents alike as a revolutionary

225. See Social Security Act, ch. 531, §§ 401-406, 49 Stat. 620, 627-29 (1935). On the name change, see Public Welfare Amendments of 1962, Pub. L. No. 87-543, § 104, 76 Stat. 172, 185.

226. See Personal Responsibility and Work Opportunity Reconciliation Act of 1996, Pub. L. No. 104-193, § 103(a), 110 Stat. 2105, 2112 (codified as amended at 42 U.S.C. $\$ \S 601-619$ (Supp. V 1999)).

227. As Linda Gordon has explained:

While Old-Age Insurance and Unemployment Compensation-Titles II and III of Social Security-were extremely controversial, ADC (Title IV) and the other public assistance programs... were uncontested. Everyone agreed that ADC would be drafted by the Children's Bureau. No one from the various technical and advisory committees that [Edwin] Witte [who directed the design of the Social Security Act] established had anything to suggest about ADC. Nothing illustrates so profoundly the maleness of the social insurance perspective as does the total silence about single mothers and children in their deliberations about this bill. Witte accepted as given, from the moment he first heard the Children's Bureau plan, that there should be federal contributions to the state and local mothers' aid programs and left the design to the bureau.

So ADC was quickly drafted by Grace Abbott, Katharine Lenroot, and Martha Eliot. Their speed reflects the fact that they anticipated no controversy and that ADC was not even the Children's Bureau's highest priority.

GoRDON, supra note 189 , at $256,147$.

228. See id. at 265-80, 284. Between 1937 and 1940, only fourteen to seventeen percent of ADC recipients were African-American, greater participation than had been allowed under the mothers' pension program but still much less than the proportion of need. See GunNar Myrdal, An American Dilemma: The Negro Problem and Modern Democracy 359 (1944). In seven southern states, moreover, African-Americans were underrepresented even compared to their proportion of the state population. African-Americans in Georgia, for instance, constituted just eleven to twelve percent of the ADC caseload between 1937 and 1940, but thirty-eight percent of the state's population under age fifteen. See $i d$. One field supervisor explained these exclusionary practices this way in the late 1930s:

"The number of Negro cases are few due to the unanimous feeling on the part of staff and board that there are more work opportunities for Negro women and to their intense desire not to interfere with local labor conditions. The attitude that 'they have always gotten along' and that 'all they'll do is have more children' is definite .... There is a hesitancy on the part of the lay boards to advance too rapidly over the thinking of their own communities which see no reason why the employable Negro mother should not continue her usually sketchy seasonal labor or indefinite domestic service rather than receive a public-assistance grant."

Mary S. Labaree, Unmarried Parenthood Under the Social Security Act, in Proceedings of the National Conference of Social Work Selected Papers Sixty-Sixth Annual Conference Buffalo, New York JUNE 18-24, 1939, at 446, 454 (1939). 
change in welfare law. ${ }^{229}$ Yet both of these successor regimes, the relatively peaceful transition and the supposed revolution, were governed to a tremendous extent by the same fundamental norms, presumptions, and modes of operation that the mothers' pension programs had adopted. Each used the provision and denial of much needed financial aid (but not, usually, the provision and denial of custody) to regulate families in which there was no father able to support his dependents, and the mother had called on the state for economic assistance. Each functioned on the guiding principle that where either parent in these families was concerned, the law needed to be suspicious of parental judgment, eager to scrutinize parental conduct, and anxious to limit parental autonomy and reshape parental relations. Meanwhile, entirely different norms and rules continued to be thought wholly appropriate for families not seen as dependent or tainted by failed fatherhood and continued to be enforced in what was officially defined as family law.

A few examples will suffice to illustrate the governing norms that shaped the programs following in the path of the mothers' pensions. Let's begin with ADC. From the start, this program was grounded in a suspicion of fathers who had failed to support their families, on the assumption that there was almost no acceptable reason for that state of affairs. Initially, ADC absolutely excluded families with two healthy parents present, and it only gave the states the option of including them in $1961 .{ }^{230}$ The language of the federal statutory scheme may have been gender-neutral (a linguistic change from many of the mothers' pension laws), ${ }^{231}$ but the underlying reasoning and the results were starkly

229. See, e.g., 141 Cong. Rec. 8496 (1995) (statement of Rep. Shaw) ("[The Personal Responsibility Act, which replaces AFDC with TANF,] is nothing short of a revolution in social policy that replaces the current failed welfare system with one that will better meet the needs of the poor and get millions into work and off welfare."); GwENDOLYN Mink, WELFARE's END 133 (1998) ("The Personal Responsibility Act removes poor single mothers from the welfare state to a police state.").

230. See An Act To amend title IV of the Social Security Act to authorize Federal financial participation in aid to dependent children of unemployed parents, and for other purposes, Pub. L. No. 87-31, \& 1, 75 Stat. 75, 75-76 (1961).

231. With one exception, the federal statutes governing the ADC program were formally genderneutral from the start, part of a trend toward using gender-neutral language in laws with a disproportionate impact on women that began even before the advent of the modern equal protection doctrine on sex discrimination. See Jill Elaine Hasday, Contest and Consent: A Legal History of Marital Rape, 88 CAL. L. Rev. 1373, 1502-03 (2000). The definition of a "'dependent child"” in the Social Security Act of 1935, for instance, included any

child under the age of sixteen who has been deprived of parental support or care by reason of the death, continued absence from the home, or physical or mental incapacity of a parent, and who is living with his father, mother, grandfather, grandmother, brother, sister, stepfather, stepmother, stepbrother, stepsister, uncle, or aunt, in a place of residence maintained by one or more of such relatives as his or their own home.

Social Security Act, ch. 531, § 406(a), 49 Stat. 620, 629 (1935). In 1968, Congress added a sex-specific provision to the statutes governing $\mathrm{ADC}$, giving states the option of providing benefits to families whose dependent children had been deprived of parental support because of their father's unemployment, but not extending the same benefits when a mother was unemployed. See Social Security Amendments of 1967, Pub. L. No. 90-248, § 203, 81 Stat. 821, 882-84 (1968). In 1979, the Supreme 
sex-specific. As its creators understood from the beginning, ${ }^{232}$ ADC, like the mothers' pension programs before it, would serve a population that included very few fathers and instead consisted overwhelmingly of poor mothers and their children. ${ }^{233}$

Even when a father was not present, moreover, the states and localities that administered ADC still evaluated women and children in terms of the men who should have been providing for them but were not. Although the Social Security Act officially opened the ADC program to children with either a dead, absent, or incapacitated parent, ${ }^{234}$ ADC administrators initially followed the pattern of the mothers' pension programs in strongly favoring widows and their children, whose husbands and fathers had the best excuse for their failure to support their dependents. ${ }^{235}$ A federal survey in 1936 and 1937, for instance, found that a full

Court, which now applied heightened scrutiny to questions of sex discrimination, held that the explicit sex-based classification in this statute violated the equal protection component of the Due Process Clause of the Fifth Amendment. See Califano v. Westcott, 443 U.S. 76, 89 (1979).

232. The legislators and policymakers who devised ADC in 1935 routinely discussed the program in sex-specific terms, operating on the explicit assumption that it would serve poor mothers and their children. See, e.g., H.R. REP. No. 74-615, at 10 (1935) ("One clearly distinguishable group of children ... for whom better provision should be made, are those in families lacking a father's support. Nearly 10 percent of all families on relief are without a potential breadwinner other than a mother whose time might best be devoted to the care of her young children."); 79 ConG. REC. 5862 (1935) (statement of Rep. Fuller) ("[In visualizing 'the great good and happiness' that ADC will bring,] I can see the careworn, dejected widow shout with joy upon returning from the neighbor's washtub after having received assurance of financial aid for her children."); see also supra note 227 and accompanying text.

233. The precise statistical evidence collected about the ADC/AFDC program varied over time, but all the available evidence confirms that the overwhelming number of adult recipients of ADC/AFDC were female. In 1961, for instance, $793,753(89.7 \%$ ) out of 884,441 surveyed families receiving ADC had a mother in the home, compared to 225,787 (25.5\%) with a father in the home. See DIVISION OF Program Statistics and Analysis, U.S. Dep't of Health, Education, and Welfare, Characteristics of Families Receiving Aid to Families with Dependent Children, November-December 1961, at tbls.12, 23 (1963). In 1971, 2,345,700 (92.9\%) out of 2,523,900 surveyed families receiving AFDC had a mother in the home, as compared to $472,900(18.7 \%)$ families with a father in the home. See National Center for Social Statistics, U.S. Dep't of Health, Education, and Welfare, Findings of the 1971 AFDC Study; Part I. Demographic and Program Characteristics tbls.16, 21 (1971). In $1981,3,412,670$ surveyed families receiving AFDC had a mother in the home $(3,076,928$ of these mothers were receiving AFDC), compared to 342,130 families with a father in the home (283,924 of these fathers were receiving AFDC). See OfFice of Policy \& Evaluation, U.S. Dep't of Health and Human Services, Findings of the May 1981-May 1982 Aid to Families with Dependent Children STUDY 6 tbl.15 (1982). In 1990, there were 3,437,784 adult female recipients of AFDC in surveyed families, and 374,187 adult male recipients. See OfFice of FAMILY Assistance, U.S. Dep't of Health and Human Services, Characteristics and Financial Circumstances of AFDC Recipients, Fy 1990, at 42 tbl.20, 46 tbl.24 (1990). In 1996, the last full year for which AFDC statistics are available, there were 3,431,682 adult female recipients in surveyed families, and 501,119 adult male recipients. See Office of Planning, Research and Evaluation, U.S. Dep't of Health and Human Services, Characteristics AND FinanCIAL CiRCuMstances of AFDC ReCipIENTS, FY 1996, at 28 tbl.22, 31 tbl.25 (1996).

234. See Social Security Act $§ 406$ (a).

235. See Hoey, supra note 190, at 76 (director of the federal Bureau of Public Assistance reporting in 1939 "that some states have been relatively slow in bringing into their new programs families who, though not eligible under their old mothers' aid laws, might legally be aided under the more inclusive provisions now in effect"). 
sixty-one percent of the mothers receiving ADC were widowed, compared to twenty-five percent who were deserted, divorced, or separated. ${ }^{236}$ In addition, only two percent of the children receiving ADC were living with mothers who had never been married, and no such cases were noted in five of the thirty states reporting. ${ }^{237}$ This strategy of devoting such a large proportion of ADC benefits to widows and their children eventually became practically implausible. The 1939 amendments to the Social Security Act, for instance, removed many widows and their children from the ADC program by making them eligible for the far more generous benefits provided under the Social Security Act's old-age and survivors insurance program, ${ }^{238}$ discussed in more detail below. ${ }^{239}$ But the normative commitments underlying $\mathrm{ADC}$ remained intact. In fact, the suspicion that ADC directed at families associated with failed fathers only intensified when widows no longer dominated the program.

Indeed, state $\mathrm{ADC}$ programs were so certain that a family's poverty generally reflected a father's moral or character failings, and were so anxious to avoid creating any incentives in that direction, that they eventually went to the extreme of seeking responsibility from men with only tenuous connections to dependent families. Here again, the practical consequences of this wide-ranging suspicion of failed fathers fell heavily on children and on mothers, who found their conduct monitored and harshly controlled. By 1968, nineteen states and the District of Columbia had adopted "substitute parent" or "man-in-the-house" rules. ${ }^{240}$ Whether these state statutes and regulations were written in genderneutral terms or sex-specific language, ${ }^{241}$ they functionally and predictably

236. See id. at $76 \&$ n. 2 .

237. See id. at 78 .

238. As originally enacted in 1935, the Social Security Act provided old-age insurance benefits only to workers. See Social Security Act $\S \S 202(a), 210$. In 1939, however, Congress amended the program before it went into effect. See id. $\S 202$ (a) (providing that old-age insurance payments would not be made until January 1, 1942). These 1939 amendments entitled wives, widows, and dependent minor children to collect old-age or survivors insurance benefits based on the employment history of a husband or father. See Social Security Act Amendments of 1939, ch. 666, § 201, 53 Stat. 1360, 1362-65. For an excellent account of the enactment of the 1939 amendments, see Alice Kessler-Harris, Designing Women and Old Fools: The Construction of the Social Security Amendments of 1939, in U.S. History as Women's History 87, 91-92 (Linda K. Kerber et al. eds., 1995) (arguing that "Congress added dependent wives and aged widows in order to shore up the legitimacy of a system in trouble. It did this by making the benefits of already-covered (mostly white) males more adequate by granting extra benefits to those who had aged wives to support and extra insurance to those with young children who survived them.").

239. See infra text accompanying notes 270-79.

240. See King v. Smith, 392 U.S. 309, 337-38 (1968) (Douglas, J., concurring). The nineteen states were: Alabama, Arizona, Arkansas, Florida, Georgia, Indiana, Kentucky, Louisiana, Michigan, Mississippi, Missouri, New Hampshire, New Mexico, North Carolina, Oklahoma, South Carolina, Tennessee, Texas, and Virginia. See id.

241. Unlike the federal ADC statutes, see supra note 231 and accompanying text, many of the state laws and regulations governing the ADC program in the 1950s and 1960s (before the Supreme Court applied heightened scrutiny to questions of sex discrimination) were written in sex-specific language. For instance, the Alabama regulation at issue in King v. Smith (1968) provided that "an "able-bodied man, married or single, [would be] considered a substitute father of all the children of the applicant- 
operated by denying a family eligibility for ADC if the mother had a sexual relationship with a man, on the categorical assumption that the family had now found a private means of support. ${ }^{242}$ This "substitute father" did not necessarily have any biological or legal connection to the mother or her children. ${ }^{243}$ But the ADC programs insisted that these men should take responsibility nonetheless and did not want to encourage them otherwise, a strategy that the programs actually pursued by refusing aid to women and their children. The Supreme Court eventually held in 1968 that the Social Security Act prohibited states from considering a man to be a child's parent for purposes of ADC eligibility, when the man was not supporting the child and had no legal obligation to do so. ${ }^{244}$ Yet the basic premise that there was virtually no excuse for a father's failure to support his family, if he was in fact the family's father, remained firmly in place. $^{245}$

The ADC program also took the fact that a mother had no husband able to provide for her family, and needed financial assistance, as grounds to doubt her competence as a parent, strictly regulate her behavior, and closely inspect her conduct. Even the Congress that enacted ADC into being assumed that any mother eligible for the new program could legitimately be suspected of unfitness, and it indicated in the committee reports accompanying the Social Security Act that states were authorized to condition ADC eligibility on an applicant's "moral character." ${ }^{246}$ By 1941, thirty-one of the forty-five states with opera-

... mother' in three different situations." 392 U.S. at 313-14 (original emphasis omitted) (quoting Alabama Manual for Administration of Public Assistance, pt. I, c. II, § VI). For other examples of state laws and regulations that were written in sex-specific language, see sources cited infra notes 242, 248.

242. Regulations issued in South Carolina in 1956, for example, stated that ADC benefits would be terminated if a man "visit[ed] frequently for the purpose of living with the [mother]," even if the man had no legal or biological relationship to the family and had made no commitment to it. 4 SouTH Carolina Dep't of Public Welfare, Poljicies and Procedures in Public Assistance 40 (Oct. 1956) (on file with author; South Carolina Department of Archives and History). "Where there [was] a pattern of the mother having a series of relationships, resulting in children or not, this [was] considered the same as if she ha[d] a continuous common-law relationship with the same man." Id. Mississippi's regulations for 1954 similarly provided that a child's assistance payments would be discontinued if the child's mother lived with a man or gave birth to an illegitimate child. See Dep'T of Public Welfare, State of MississipPI, НАNDBOок 62 (July 1, 1954) (on file with author; Mississippi Department of Archives and History). For an example of a substitute father rule in operation, see Rios v. Hackney, 294 F. Supp. 885, 886 (N.D. Tex. 1967) (turning on the question of whether the plaintiff "was or had been cohabiting with a man who was not the legal father of the minor plaintiffs, her children, which fact, if established, would have required that public welfare funds be withheld from plaintiffs under the 'substitute father' regulation adopted by the defendant Board of Public Welfare").

243. See sources cited supra note 242.

244. See King, 392 U.S. at 329-30. In the wake of the Supreme Court ruling, the Department of Health, Education, and Welfare (HEW) issued a regulation, upheld in 1970, that established that states could also not assume that the child had access to the man's income. See Lewis v. Martin, 397 U.S. 552, 554, 559-60 (1970); 45 C.F.R. $§ 203.1$ (1969).

245. The King opinion, for instance, reported with approval that Congress had made "[e]very effort ... to locate and secure support payments from persons legally obligated to support a deserted child." King, 392 U.S. at 332.

246. S. ReP. No. 74-628, at 36 (1935); H.R. Rep. No. 74-615, at 24 (1935); see also 79 Cong. ReC. 5679 (1935) (statement of Rep. Jenkins) ("I think every child is entitled to the care of its mother if she 
tional ADC programs had promulgated what were known as "suitable home" rules, ${ }^{247}$ which regulated mothers by threatening to withdraw the financial assistance on which they and their children depended. ${ }^{248}$ Florida's suitable home law of 1959 , for instance, provided that a home would be considered unsuitable for purposes of ADC eligibility if the parent living with the child (virtually always the mother) failed "to provide a stable moral environment for the child, by engaging in promiscuous conduct either in or outside the home, or by having an illegitimate child after receiving an assistance payment from the department, or by otherwise failing to demonstrate an intent to establish a stable home." 249

States frequently used surprise home visits, or required scheduled inspections, to monitor compliance with their suitable home (and substitute father) rules. These visits, often conducted in the middle of the night or the early morning if the object was to take the family by surprise, operated on the premise that mothers receiving economic assistance because of failed fatherhood required and deserved a form and level of scrutiny that would have appeared absolutely unnecessary and inappropriate if directed at more financially successful families. ${ }^{250}$

is at all worthy."). The federal Bureau of Public Assistance endorsed suitable home policies in 1940 See Bureau of Public Assistance, Federal Security Agency, Bureau Circular No. $9 \S 209$, at 1 (May 1, 1940), quoted in Winifred Bell, Aid to Dependent ChILdRen 35-36 (1965). However, it retracted its endorsement in 1945 (without prohibiting the policies) on the ground that:

The "suitable home" provision ... may be in part an expression of the community's concern for the protection of the welfare of the children in that sector of the population in which families suffer more than average hazards. This provision, if it is used as an eligibility requirement, will not, however, protect children. It simply precludes them from receiving aid to dependent children.

Jane M. Hoey, Bureau of Public Assistance, Federal Security Agency, State Letter No. 46 to State Agencies Administering Approved Public Assistance Plans: "Suitable Home" Provisions of State Plans for Aid to Dependent Children 3 (Mar. 5, 1945) (on file with author; Library of the Office of Family Assistance). For a similar passage in a published summary of State Letter No. 46, see "Suitable Home" Provisions of State Plans for Aid to Dependent Children, Soc. SecurtTy Bull., Apr. 1945, at 19, 19.

247. See BELL, supra note 246 , at 30.

248. Like the mothers' pension laws before them, state ADC programs primarily relied on the provision and denial of financial aid, rather than the removal of children from their parents' custody. Only approximately $0.5 \%$ of the children affected by Florida's 1959 suitable home law, for example, were actually removed from their homes by court order. See Roland J. Chilton, Consequences of a State Suitable Home Law for ADC Families IN Florida 202 (1968). In 1960, the Louisiana Legislature enacted a suitable home law that disqualified a family if the mother had ever given birth to an illegitimate child while receiving ADC payments, unless the family could convince their local welfare administrators "that the mother ha[d] ceased illicit relationships and [was] maintaining a suitable home for the child or children." Act No. 251, § 1, 1960 La. Acts 525, 527. Under this policy, over twenty-three thousand children were dropped from the ADC rolls in the summer of 1960, but left at home. See Bureau of Public Assistance, U.S. Dep't of Health, Education, and Welfare, Review of Practice Under the Suttability of Home Policy in Aid to Dependent Children in Louisiana, JUNE-OCTOBER 1960, at 10 (1960).

249. House Bill No. 312, § 2, 1959 Fla. Laws ch. 59-202; see also supra note 248 (describing Louisiana suitable home statute).

250. Given the poor's chronic lack of access to counsel before the mid-1960s, see infra notes 285-86 and accompanying text, authoritative legal sources generally considered and reported the 
As in the mothers' pension programs, women (and children) applying for or receiving ADC were measured and governed through a set of judgments about the men to whom they were or should have been attached. Women associated with failed male providers found their reproductive work automatically devalued, their skill as mothers openly questioned, and their morality (especially in sexual matters) immediately in doubt and rigidly regulated. Indeed, states with suitable home policies took it upon themselves to assume a place among the single mothers receiving ADC akin to that of a jealous and suspicious husband, distrustfully scrutinizing a woman's behavior for signs of laxity or licentiousness and refusing to tolerate sexual conduct outside of marriage. Children's claims to ADC, in turn, revolved around the state's exacting assessment of their mothers' conduct. The suitable home rules, remember, functioned by denying aid to needy children as well as to their mothers.

Congress, for its part, placed some limits on the harshness of suitable home rules in 1962, requiring states that excluded "unsuitable" families from ADC to provide those families with "adequate care and assistance" from general relief

surprise visits that government investigators made to the homes of ADC recipients only in the context of government prosecutions based on evidence obtained this way. For examples of these accounts, see People v. Shirley, 360 P.2d 33, 34 (Cal. 1961) (in bank) ("The social worker visited defendant at her home.... and found a Mr. Shirley there, fully clothed but wearing bedroom slippers. Two days later, ... investigators from the district attorney's office called at defendant's home about 2:30 a.m. and found Shirley in bed in her bedroom."); People v. Rozell, 28 Cal. Rptr. 478, 480 (Dist. Ct. App. 1963) ("An investigator of the district attorney's office visited Mrs. Rozell's residence in October 1961 about 10:45 one evening. Wilson Colvin was in the home and articles of men's clothing were discovered .... A social worker stated that on January 15, 1962, she visited Mrs. Rozell ... [W]hen Mrs. Rozell opened the door [the social worker] walked to the kitchen in time to see a man running out the back door."); People v. Phipps, 12 Cal. Rptr. 681, 683 (Dist. Ct. App. 1961) ("Between 2:00 and 3:00 a.m. on January 28, 1959, investigators went to the Phipps home to investigate the truth of reports that $\mathrm{Mr}$. Phipps was frequenting the home of Mrs. Phipps."); and Blackmone v. United States, 151 A.2d 191, 194 (D.C. 1959) ("[T]hree investigators of the Department of Public Welfare went to the house occupied by Mrs. Blackmone. Two of them went to the rear of the premises, and after a short wait, they observed a man running from the rear door in his bare feet and shirt sleeves."). Most legal academics writing before the mid-1960s followed the courts in paying little, if any, attention to the practice of surprise visits. In 1963, Charles Reich wrote one of the first academic articles to ever consider the subject, relying in part on the accounts of surprise visits revealed during prosecutions. See Charles A. Reich, Midnight Welfare Searches and the Social Security Act, 72 YALE L.J. 1347, 1352-53 (1963).

By the late 1960s, federal regulations required state ADC agencies to refrain, in "taking applications and determining eligibility for assistance," from "practices that violate[d] the individual's privacy or personal dignity, or harass[ed] him, or violate[d] his constitutional rights." U.S. DEP'T OF HeALTH, Education, and Welfare, Handbook of Public Assistance Administration $\S 2300$ (a) (1969). These regulations advised states to

especially guard[] against violations of legal rights and common decencies in such areas as entering a home by force, or without permission, or under false pretenses; making home visits outside of working hours, and particularly making such visits during sleeping hours; and searching in the home, for example, in rooms, closets, drawers, or papers, to seek clues to possible deception.

Id. Many states, however, continued to require ADC recipients to submit to home visits as a condition of aid, and the Supreme Court upheld the constitutionality of this practice in 1971. See infra text accompanying notes $288-310$. 
rolls that typically provided less aid. ${ }^{251}$ But with that caveat in place, suitable home rules and their governing logic of suspicion remained a part of the ADC program throughout its life. ${ }^{252}$

The TANF program, which replaced ADC, operates on similar principles. TANF was enacted as part of the Personal Responsibility Act of $1996,{ }^{253}$ a law most prominently defended and explained in the Contract with America that served as a unifying campaign document for House Republicans in the 1994 election. ${ }^{254}$ The Contract, like the ADC program before it, identified fathers as the family members preeminently responsible for the financial maintenance of their offspring. ${ }^{255}$ It acknowledged, moreover, essentially no legitimate reason why a father might not be able to provide for his children, explaining that the fathers of children receiving ADC had responded strategically to the perverse incentives toward irresponsibility supposedly created by the ADC program itself. ${ }^{256}$ But the Contract also took a mother's economic need, and the fact that

251. Public Welfare Amendments of 1962, Pub. L. No. 87-543, $\S 107$ (b), 76 Stat. 172, 189. A year before this statute was enacted, Arthur Flemming, then in his final days as Secretary of HEW, had issued what became known as the "Flemming Ruling." See Bureau of Public Assistance, Dep't of Health, Education, and Welfare, State Letter No. 452 (Jan. 17, 1961), reprinted in Appendix at 278-80 (plaintiffs' exhibit 1), King v. Smith, 392 U.S. 309 (1968) (No. 949). This ruling had not prohibited states from employing suitable home policies. Indeed, it endorsed the use of such policies, explaining that " $[w]$ henever there is a question of the suitability of the home for the child's upbringing, steps should be taken to correct the situation or, in the alternative, to arrange for other appropriate care of the child." Id. at 279. But the Flemming Ruling had barred state ADC programs from disqualifying a family based on the unsuitability of its home, when the state left the children in that home. See id. ("E]ffective July 1, 1961: A State plan for aid to dependent children may not impose an eligibility condition that would deny assistance with respect to a needy child on the basis that the home conditions in which the child lives are unsuitable, while the child continues to reside in the home."). Congress's 1962 statute represented a weakening of this standard.

252. See 45 C.F.R. $\$ 233.90$ (b)(1) (2000) ("A child may not be denied AFDC either initially or subsequently 'because of the conditions of the home in which the child resides', or because the home is considered 'unsuitable', unless 'provision is otherwise made pursuant to a State statute for adequate care and assistance with respect to such child'." (quoting Social Security Act § 404(b))).

253. See Personal Responsibility and Work Opportunity Reconciliation Act of 1996, Pub. L. No. 104-193, § 103(a), 110 Stat. 2105, 2112 (codified as amended at 42 U.S.C. $\S \S 601-619$ (Supp. V 1999)).

254. See Contract with America: The Bold Plan by Rep. Newt Gingrich, Rep. Dick Armey and the House Republicans to Change the Nation 6 (Ed Gillespie \& Bob Schellhas eds., 1994).

255. In important respects, the Contract's TANF proposal operated on the premise that healthy family life depended on economic support by a male breadwinner. Indeed, the proposal was importantly structured on the assumption that forcing men to take financial responsibility for their children was a key solution to poverty and dependency. As the Contract repeatedly stressed, its TANF program required mothers to "identify the fathers [of their children] as a condition for receiving AFDC payments [as well as food stamps and public housing], except in cases of rape and incest." Once identified, most fathers of children receiving TANF would be subject to a child support suit by the state. Id. at 66; see also id. at 69,71. In addition, a number of other provisions structured the provision of aid under TANF in order to increase both a mother's and a father's incentives to marry. For example, "mothers age eighteen who [gave] birth to illegitimate children [had to] live at home in order to receive aid-unless the mother marrie[d] the biological father or marrie[d] an individual who legally adopt[ed] the child." Id. at 70-71.

256. See id. at 65 ("Isn't it time for the government to encourage work rather than rewarding dependency? The Great Society has had the unintended consequence of snaring millions of Americans 
her children had no father financially supporting them, as grounds for suspecting her judgment as a parent, discounting the value of her reproductive labor, and constraining her autonomy. Like the ADC program, the Contract judged and regulated women linked to failed fathers on the basis of their association with these unsuccessful family men. In fact, the Contract assumed from the start that the principles it endorsed and the restrictions it proposed would operate most directly on women and their children, ${ }^{257}$ who would constitute the overwhelming majority of TANF recipients even though the program's statutory scheme would be formally gender-neutral. ${ }^{258}$

In particular, the Contract was explicitly determined to use the government's

into the welfare trap. Government programs designed to give a helping hand to the neediest of Americans have instead bred illegitimacy, crime, illiteracy, and more poverty."); id. at 75 ("Republicans understand one important thing ignored by most Democrats-incentives affect behavior .... It's time to change the incentives and make responsible parenthood the norm and not the exception.").

257. In advocating the adoption of TANF, the Contract routinely and systematically assumed that the adults who would receive TANF and be subject to its conditions would be mothers. See, e.g., id. at 66 ("Mothers under the age of eighteen may no longer receive AFDC payments for children born out of wedlock and mothers who are ages eighteen, nineteen, and twenty can be prohibited by the states from receiving AFDC payments and housing benefits."); id. at 68 ("Although almost half of the mothers who enter AFDC can be expected to leave within two years, most return. Long-term users often are young, never married, and high school dropouts; and most AFDC families begin with a birth to a teenager."); $i d$. at 70 ("The savings generated from this provision to deny AFDC to minor mothers (and to mothers age eighteen to twenty if the state elects that option) is returned to the states in the form of block grants to provide services--but not cash payments-to help these young mothers with illegitimate children.").

258. The Personal Responsibility Act requires every state TANF program to provide the federal government with a wide variety of demographic information about the people receiving TANF. Interestingly enough, this statute, which requires data about age, marital status, race, educational status, and citizenship, does not specifically instruct the states to compile information about the sex of TANF recipients. See Personal Responsibility and Work Opportunity Reconciliation Act of $1996 \S 411$ (codified at 42 U.S.C. $\$ 611$ (Supp. V 1999)).

After the Personal Responsibility Act was enacted, the federal administrative office with jurisdiction over TANF, the Administration for Children and Families in the U.S. Department of Health and Human Services, proposed rules to require state TANF programs to collect sex-based statistics. See Temporary Assistance for Needy Families Program (TANF), 62 Fed. Reg. 62,124, 62,172, 62,180 (proposed Nov. 20, 1997) (to be codified at 45 C.F.R. pts. 270-75). But the federal regulators did not immediately require states to collect such information. See Office of Planning, Research, and Evaluation, U.S. Dep't of Health and Human Services, Transmittal No. TaNF-ACF-PI-97-6, Temporary Assistance for Needy Families Program: Program Instruction (1997) (Emergency TANF Data Report).

Accordingly, the federal government does not have any sex-based statistics for TANF from the start of the program through the end of fiscal year 1999. See Temporary Assistance for NeEdy Families (TaNF) Program, U.S. Dep't of Health and Human Services, Characteristics and Financial Circumstances of TANF Recipients, Fiscal Year 1999, at 1-7 (1999); Temporary Assistance for Needy Families (TANF) Program, U.S. Dep't of Health and Human Services, Characteristics and Financial Circumstances of TANF Recipients, Fiscal Year 1998, at 1-5 (1998); Temporary Assistance for Needy Families (TANF) Program, U.S. Dep't of Health and Human Services, Characteristics and Financial Circumstances of TANF ReCipients, July-September 1997, at 1-4 (1997).

However, the federal government's final rules for data collection, issued in April 1999, require state TANF programs to submit information about the sex of the people receiving TANF. See Temporary Assistance for Needy Families Program (TANF), 64 Fed. Reg. 17,720, 17,907, 17,910, 17,912, 17,922, $17,925,17,927$ (Apr. 12, 1999) (to be codified at 45 C.F.R. pts. 260-65). The first such statistical information, for fiscal year 2000, is scheduled to be published in December 2001. See E-mail from Sean D. Hurley, Administrator, Office of Planning, Research, and Evaluation, Administration for Children 
power to provide or deny financial support to women receiving TANF as a means of affecting their reproductive decisions in the direction of constraining childbearing. On the Contract's account, women who were rearing children by themselves while receiving ADC were not performing "work." Their caretaking simply did not count as "a productive job" worth recognizing or rewarding. ${ }^{259}$ The Contract promised that its proposed legislative reform would reduce the number of children that TANF recipients bore by making raising children under TANF extremely arduous. ${ }^{260}$

The Personal Responsibility Act that Congress enacted included dramatic manifestations of this commitment. Perhaps most strikingly, it permits states to freeze a family's benefit levels if the mother bears an additional child while receiving TANF, ${ }^{261}$ and offers a substantial annual bonus to the five states that reduce their illegitimate births by the greatest amount. ${ }^{262}$ By October 1997, twenty-two state TANF programs had so-called "family cap" or "child exclusion" policies in place. Seventeen of these states provided no additional TANF

and Families, U.S. Dep't of Health and Human Services, to Jill Hasday (Oct. 30, 2001) (on file with author).

Although the statistics are not yet available, there is no reason to think that the sexual composition of the TANF population differs markedly from the sexual composition of the ADC population, in which adult women vastly outnumbered adult men. See supra note 233 and accompanying text. Indeed, this is perhaps one reason why the Personal Responsibility Act overlooked the need for sex-based statistics. The sexual composition of the TANF population was so predictable that it might have been taken to be a matter of common knowledge not requiring more rigorous analysis.

259. Contract with AMERICA, supra note 254, at 65 ("To ensure that welfare offers a helping hand rather than a handout, we require that welfare beneficiaries work so they can develop the pride and self-sufficiency that comes from holding a productive job."); see also id. at 67 ("More than twenty-five years later, Johnson's War on Poverty has been an unqualified failure. Despite spending trillions of dollars, it has had the unintended consequence of making welfare more attractive than work to many families...."); id. at 69 (noting that the Contract's TANF proposal "requires 50 percent of AFDC recipients to work by 1996 ").

260. See, e.g., id. at 65 ("To reverse skyrocketing out-of-wedlock births that are ripping apart our nation's social fabric, we provide no welfare to teenage parents and we require that paternity and responsibility be established in all illegitimate births where welfare is sought."); id. at 70 ("The Personal Responsibility Act is designed to diminish the number of teenage pregnancies and illegitimate births.").

261. See Personal Responsibility and Work Opportunity Reconciliation Act of $1996 \S 103$ (a) (codified at 42 U.S.C. $\S 602(a)(7)(A)(i i i)$ (Supp. V 1999)). The Contract with America had advocated making the family cap a mandatory part of the TANF program. See CoNTRACT WITH AMERICA, supra note 254 , at 70-71 ("The bill also includes a number of other provisions to reduce illegitimacy .... Mothers already receiving AFDC will not receive an increase in benefits if additional children are born out of wedlock.").

262. See Personal Responsibility and Work Opportunity Reconciliation Act of $1996 \S$ 103(a) (codified as amended at 42 U.S.C. $\$$ 603(a)(2) (Supp. V 1999)). This provision was amended in 1997 so that the annual bonus is awarded to the five states that reduce their proportion of illegitimate births by the greatest amount, rather than the five states that reduce their absolute number of illegitimate births by the greatest amount. See Balanced Budget Act of 1997, Pub. L. No. 105-33, § 5502(b), 111 Stat. 251, 607. The 1997 amendment did not alter the requirement that a state is only entitled to a bonus if its abortion rate for the year in question is lower than its abortion rate for 1995. See Personal Responsibility and Work Opportunity Reconciliation Act of $1996 \S 103$ (a) (codified as amended at 42 U.S.C. $\S 603(\mathrm{a})(2)(\mathrm{C})(\mathrm{i})(\mathrm{I})(\mathrm{bb})$ (Supp. V 1999)). 
benefits for a child conceived and born while her mother was receiving TANF, and the rest provided for reduced or restricted increases in aid. ${ }^{263}$

ADC and TANF have continued the law's tradition of interventionist and instrumental regulation directed at poor families without a father able to support them. But although these programs regulate the rights, responsibilities, and relationships of family members, they (like their predecessors) are not considered part of, or even relevant to, what is authoritatively defined as family law. Family law as it is officially understood-the family law that governs more economically successful families-continues to support and enforce the same basic principles of deference to parental prerogatives that characterized the common law. Government programs regulating families considered financially self-sufficient, moreover, track these "official" presumptions and norms, even when distributing financial aid.

The state of the law in the 1950s and 1960s provides a good initial vantage point for considering this continued, and unexamined, bifurcation. These were decades that saw the ADC program at perhaps its most aggressive, ${ }^{264}$ but the authoritative accounts of family law in this era betrayed no sign of that. Instead, they articulated slight variations on the positions that common law courts had endorsed over a century before, and affirmed the law's consistent commitment to protecting parental authority. William Prosser, author of the most influential torts treatise in the middle of the twentieth century and reporter for the second restatement of torts, ${ }^{265}$ made the historical continuity with common law principles explicit in discussing a parent's right of correction. "A husband or father, as the head of the household, was recognized by the early law as having

263. See L. Jerome Gallagher et al., Urban Institute, One Year After Federal Welfare Reform: a Description of State Temporary Assistance for Needy Families (TANF) Decisions as of October 1997, at VI-8 (1998). By February 1999, twenty-three states had some form of family cap policy in place. See Shelley Stark \& Jodie Levin-Epstein, Center for Law and Social Policy, Excluded Children: Family Cap in a New Era 3 (1999).

So far, the evidence on the effect that family cap provisions have on birth rates is still sketchy and inconclusive. As of 1999 , only two of the first fourteen states to enact family cap policies, Arkansas and New Jersey, had completed studies comparing the behavior of welfare recipients who were subject to a family cap to similar recipients who were not. See id. at 6 \& 18 n.24 (noting that Arizona's evaluation period will end in June 2002). Arkansas's study, begun in 1994 and completed in 1997, found that the state's family cap policy had no statistically significant effect on birth rates. See CAROLYN TURTURRO ET al., The University of Arkansas at Little Rock School of Social Work, Arkansas Welfare Waiver Demonstration Project: Final Report, July, 1994 Through June, 1997, at 1-2 (1997). Capped families experienced an average of 0.16 births during the studied period, as compared to an average of 0.14 births among the control group. See id. at 80 . New Jersey's study, begun in 1993 and completed in 1996, reported a significant effect on birth rates, but also a rise in abortion rates. See MichaEL. J. Camasso et al., A Final Report on the Impact of New Jersey's Family Development Program, at v (1998). Among ongoing welfare cases, families subject to the state's family cap experienced a birth rate that was approximately nine percent lower than the birth rate for families in the control group. See id. Among new welfare cases, families subject to the family cap experienced a birth rate that was twelve percent lower than the birth rate for families in the control group. However, the abortion rate among the families new to welfare was fourteen percent higher in the group subject to the family cap. See id.

264. See supra text accompanying notes $230-52$.

265. See Restatement (SECOND) of Torts, at iii (1965). 
authority to discipline the members of his family," Prosser explained. ${ }^{266}$ "As to children, the privilege remains, despite any modern theories that to spare the rod is not to spoil the child. A parent, or one who stands in the place of a parent, may use reasonable force, including corporal punishment, for discipline and control." ${ }^{267}$ The Model Penal Code, in turn, reported that family law, properly understood, was even more deferential to parental prerogatives. The code's drafters stated, for instance, that requiring a parent to use only reasonable force was "too extreme" a curb on parental authority. ${ }^{268}$ As they elaborated, "so long as the person exercising parental authority acts for the purpose of safeguarding or promoting the child's welfare (including the specific purpose of preventing or punishing misconduct), we think he should be privileged in penal law unless he culpably creates substantial risk of . . . excessive injuries." 269

These official accounts of family law ignored, and were at odds with, the norms and presumptions that governed the ADC program, which was driven by suspicion of parental judgment, and an eagerness to scrutinize parental conduct and constrain parental behavior. Yet the norms endorsed in the twentieth century's authoritative accounts of family law did shape many modern government programs that regulated family relationships and determined the legal rights and responsibilities of family members, but were not popularly associated with failed fatherhood. Two examples nicely illustrate this pattern: The first involves a program promulgated alongside ADC, and the second focuses on some of the proposed bills introduced at the same time as TANF.

The 1935 Social Security Act that created ADC also established a program of old-age and survivors insurance, ${ }^{270}$ which is today commonly referred to simply as "Social Security." In addition to entitling workers to old-age benefits based on their history of paid employment, ${ }^{271}$ this program provides financial support to the spouses, ${ }^{272}$ dependent minor children, ${ }^{273}$ and dependent parents of these workers. ${ }^{274}$ Like ADC or TANF, the Social Security program is a form of family law, structuring the legal rights and responsibilities that family members have

266. William L. Prosser, Handbook of the Law of Torts 139 (3d ed. 1964).

267. Id.; see also RESTATEMENT (SECOND) OF TORTS, supra note $265, \S 147(1)$ ("A parent is privileged to apply such reasonable force or to impose such reasonable confinement upon his child as he reasonably believes to be necessary for its proper control, training, or education.").

268. Model Penal Code $\S 3.08 \mathrm{cmt} .1$, at 71 (Tentative Draft No. 8, 1958).

269. Id. The Model Penal Code defined "excessive injuries" as "death, serious bodily harm, disfigurement, extreme pain or mental distress or gross degradation." Id. \$3.08(1)(b), at 69.

270. See Social Security Act, ch. 531, §§ 1-210, 49 Stat. 620, 620-25 (1935). For a discussion of the crucial 1939 amendments to the Social Security Act that entitled wives, widows, and dependent minor children to receive old-age or survivors insurance benefits based on the record of employment that a husband or father had established, see supra note 238 and accompanying text.

271. See 42 U.S.C. $\$ 402$ (a) (1994) (old-age insurance benefits).

272. See id. $\S 402$ (b) (wife's insurance benefits); id. $\S 402$ (c) (husband's insurance benefits); id. $\S 402$ (e) (widow's insurance benefits); id. $\S 402$ (f) (widower's insurance benefits).

273. See id. \$ 402(d) (child's insurance benefits).

274. See id. $\S 402(\mathrm{~g})$ (mother's and father's insurance benefits); id. $\S 402(\mathrm{~h})$ (parent's insurance benefits). 
based on their family status. In many ways, it is also a redistributive scheme designed to respond to economic need among families in which the male breadwinner has stopped working or died. Large numbers of Social Security recipients collect much more money from the program than they or their family members ever paid in Social Security taxes. ${ }^{275}$ But receiving Social Security is not culturally taken to be a mark of economic dependency or failed fatherhood. Instead, Social Security is popularly characterized as a benefit that husbands and fathers (and, significantly less frequently, wives and mothers) ${ }^{276}$ have earned for themselves and their families through their employment. ${ }^{277}$ Accordingly, the authors of Social Security, operating on principles implicitly understood but never fully explained, have seen no reason to deviate from the norms conventionally associated with family law.

In the Social Security program, as in ADC or TANF, the legal treatment that women and children receive importantly turns on judgments about the men who head or should head their households. The husbands and fathers who are the primary beneficiaries under the Social Security program are considered successful and self-reliant family men, and they, along with their wives and children, are therefore subject to deference and respect rather than scrutiny and suspicion. The Social Security program protects family autonomy and self-government in ways that contrast starkly with the presumptions guiding a legal regime like ADC or TANF. The latter programs, regulating women and children associated with failed fathers, discount both paternal and maternal judgment, closely monitor parents, and control their behavior. ${ }^{278}$ In contrast, the payments that the Social Security program distributes to family members are entitlements that recipients enjoy solely because of their family status. The Social Security

275. See Michael J. Boskin et al., Social Security: A Financial Appraisal Across and Within Generations, 40 NAT'L TAX J. 19, 22 (1987); Michael D. Hurd \& John B. Shoven, The Distributional Impact of Social Security, in Pensions, Labor, AND Individual Cholce 193, 193 (David A. Wise ed., 1985).

276. Most female recipients of Social Security collect spousal benefits, rather than benefits based on their own work histories. In 1999, for example, only $37.6 \%$ of the women aged 62 or older who were receiving Social Security collected benefits based on their own work records. In contrast, $35.1 \%$ of the female recipients collected spousal benefits because their employment histories did not qualify them for worker benefits at all. The other $27.3 \%$ could have collected benefits based on their own work histories, but instead collected spousal benefits because they entitled the women to higher payments. See SocIAL Security Administration, Annual Statistical Supplement to the Social Security Bulletin, 2000, at 177 tbl.5.A 14, 345 (2001).

277. For accounts of how this cultural understanding of the Social Security program was created, see Jerry R. Cates, Insuring Inequality: Administrative Leadership in Social Security, 1935-54, at 104 (1983) ("The phrase social security as used in the 1935 Act meant public assistance as well as conservative social insurance. Over the years, the phrase has come to mean, for most people, only the social insurance system. This is symbolic of and, in part, attributable to the SSB's [Social Security Board's] drive to segregate social insurance from public assistance and to identify the agency with the more desirable of the two systems."); and Fraser \& Gordon, supra note 56, at 322 ("Equally deliberate was the construction of the differential in legitimacy between the two tracks of the welfare system. The Social Security Board propagandized for Social Security Old Age Insurance . . . precisely because, at first, it did not seem more earned or more dignified than public assistance.").

278. See supra text accompanying notes $230-63$. 
program does not investigate whether recipients are fit parents, or children, or wives, or husbands; no morals or sexual relationships are examined, no households inspected. When a man entitled to Social Security dies or retires, his wife and his dependent minor children are automatically entitled to receive Social Security benefits. ${ }^{279}$ When a man is absent or incapacitated in a family applying for ADC or TANF, the requirements, regulations, and restrictions governing benefits to that mother and her children whirl into activity.

The Contract with America that introduced TANF was similarly committed to protecting familial autonomy and parental judgment, where families not tainted with failed fatherhood were concerned. The same Contract that endorsed the Personal Responsibility Act also proposed a number of bills designed to increase other parents' rights of control and privacy, and to provide these supposedly self-sufficient parents with considerable financial support. The "Family Reinforcement Act," for instance, would have given parents the right to prevent their children from participating in any federally funded survey or analysis that would question children about their family's political, medical, sexual, financial, or religious characteristics. ${ }^{280}$ It also included a tax credit of up to $\$ 5000$ for families adopting a child, and a $\$ 500$ tax credit for families with a dependent elderly parent or grandparent at home. ${ }^{281}$ The Contract explained that this bill reflected a determination to support parents on the conviction that "parents know what's best for their children-not the government."282 The Contract similarly championed another bill, which would have reduced taxes, on the ground that it would enable women in two-parent, "middle-class families" to stay at home and personally supervise their children. ${ }^{283}$ TANF, of course, hardly operated on such principles of deference and respect, or evinced such concern about the value of mothers' reproductive labor. ${ }^{284}$ But the Contract took it as a matter of (unstated) fact that its TANF proposal, and the future TANF recipients, were somehow outside the confines of family law.

\section{B. THE EVASION OF CRITICAL SCRUTINY}

The bifurcation in the legal regulation of parenthood has endured for more than a century, but has never been fully acknowledged, explained, or justified. The Contract with America, for instance, never actually indicates why opposing norms should govern the Personal Responsibility Act and the other bills to regulate families that the Contract endorses. The Social Security program has

279. See statutory provisions cited supra notes $271-74$.

280. See Contract with America, supra note 254, at 80-81. This bill was introduced in the House of Representatives on January 4, 1995. See Family Reinforcement Act, H.R. 11, 104th Cong. (1995).

281. See Contract WITH AMErica, supra note 254, at 80-81.

282. Id. at 83 .

283. Id. at 15 (explaining that current tax rates were forcing "middle-class families" to put "a second earner [read: wife and mother] in the market not to support the household but to support the cost of government").

284. See supra text accompanying notes 253-63. 
never explicitly addressed why the rules and presumptions that it operates under should be so different from those shaping ADC or TANF. Authoritative accounts of family law, in turn, make no reference to the tradition of legal regulation that extends from the child cruelty societies to the Personal Responsibility Act.

In part, the divide in the law's treatment of parental relations has evaded critical scrutiny in political and popular discourse precisely because family law is still officially and commonly defined to include only those rules that govern families deemed financially self-reliant. The legal regimes that have emerged to regulate families tainted by failed fatherhood and economic dependency are not conventionally counted as being part of family law. Although they regulate the rights, obligations, and relationships of family members, they are typically considered to fall within the sole jurisdiction of the law of poverty or welfare, rather than being recognized as forms of welfare that are also and at the same time forms of family law. This way of classifying and envisioning the law helps obscure the division in the legal regulation of parental relations, by safely placing opposing regimes into different legal categories. Phrased another way, the assumption that examples of social welfare regulation or poverty law cannot also be instances of family law helps preserve the illusion that the law of parenthood has remained pastoral and largely unchanged over time, by defining this body of law to include only those forms of regulating family life that still reflect the common law tradition.

More importantly, however, the protection that our existing constitutional framework accords to the bifurcation in the law of parenthood has collapsed sustained normative debate about whether particular transfers of money should be the occasion for a complete reversal in the norms and presumptions that the law employs to govern parents. Contemporary constitutional jurisprudence makes it virtually impossible to mount a successful legal challenge against government programs that condition the provision of crucial financial support to poor families on their surrender of legal and constitutional rights to autonomy and privacy that they would otherwise possess. Indeed, modern courts considering the bifurcation in the law's treatment of parenthood have reasoned from within the same structure that produced the bifurcation in the first place, adopting the perspective of the divide's creators without questioning or rigorously examining any of their premises. With few opportunities in constitutional law to discuss or remedy the bifurcated normative regime governing the law of parenthood, the issue has not attracted much sustained interest or analysis.

The poor's chronic lack of access to counsel meant that courts were slow to hear any cases that challenged the divide in the legal regulation of parenthood. ${ }^{285}$ But after the federal government began funding legal assistance for the

285. Indeed, King v. Smith, 392 U.S. 309 (1968), which considered Alabama's substitute parent regulation, see id. at 311, was the first Supreme Court opinion to review any aspect of the ADC program, in operation since 1935 . Only two Supreme Court opinions before King even use the terms ADC or AFDC. See Damico v. California, 389 U.S. 416, 416-17 (1967) (per curiam) (holding that 
poor in the mid-1960s, ${ }^{286}$ a number of suits were brought raising the issue. ${ }^{287}$ They quickly encountered almost insuperable obstacles. In particular, one case that reached the Supreme Court proved especially pivotal.

As discussed above, state ADC programs routinely policed compliance with their policies by inspecting the homes of families receiving support. ${ }^{288} \mathrm{New}$ York, like at least fifteen other states, ${ }^{289}$ had statutes and regulations that required ADC recipients to consent to these "home visits" as a condition of aid. ${ }^{290}$ Barbara James, the plaintiff in Wyman v. James (1971), had been expelled from New York's ADC program because she refused to agree to such a visit, and she sued challenging the constitutionality of New York's rule. ${ }^{291}$ James based her claim on precedent establishing that government agents lack the constitutional authority to search a person's home without a warrant, ${ }^{292}$ relying on an emerging legal argument that commentators generally term the doctrine of "unconstitutional conditions." 293

This argument was based on a number of Supreme Court cases decided in the years before Wyman that appeared to endorse the proposition that governments cannot condition the receipt of public benefits on the waiver of constitutional rights, unless the government has a legitimate interest, unrelated to compromising constitutional rights, in imposing the condition. Many of the leading cases in this line of jurisprudence had addressed, in particular, the terms on which a state government could distribute financial support or public employment, although none had involved a program as culturally stigmatized as ADC. In Speiser v. Randall (1958), ${ }^{294}$ for instance, a group of veterans had sued challenging the constitutionality of a California law that conditioned eligibility for a veterans' property tax exemption on the veteran's willingness to sign a loyalty

welfare claimants could pursue their claims for relief under the Civil Rights Act, even though they had not first sought relief under state law providing administrative remedies); Lynumn v. Illinois, 372 U.S. 528, 533-34 (1963) (holding that petitioner's oral confession was coerced where police threatened her with the termination of her ADC payments and the loss of her children).

286. See Frances Fox Piven \& Richard A. Cloward, Regulating the Poor: The Functions of Public Welfare 248-340 (1971).

287. See, e.g., Dandridge v. Williams, 397 U.S. 471, 474-75, 486-87 (1970) (rejecting a constitutional challenge against a Maryland regulation that limited the amount of ADC benefits that a family could receive to $\$ 250$ a month, regardless of family size); King, 392 U.S. at 333 (holding that Alabama's substitute parent regulation was inconsistent with the Social Security Act, and accordingly not reaching the constitutional issue).

288. See supra note 250 and accompanying text.

289. See Jurisdictional Statement of Appellant Wyman at 14 n.*, Wyman v. James, 400 U.S. 309 (1971) (No. 69).

290. See Wyman, 400 U.S. at 311-12.

291. See id. at 313-14.

292. See id. at 312-13.

293. See, e.g., Richard A. Epstein, Unconstitutional Conditions, State Power, and the Limits of Consent, 102 Harv. L. Rev. 4 (1988); Kathleen M. Sullivan, Unconstitutional Conditions, 102 HaRv. L. REv. 1415 (1989); Cass R. Sunstein, Why the Unconstitutional Conditions Doctrine Is an Anachronism (with Particular Reference to Religion, Speech, and Abortion), 70 B.U. L. Rev. 593 (1990).

294. 357 U.S. 513 (1958). 
oath. ${ }^{295}$ The Supreme Court struck down the California law, reasoning that " $[t] \mathrm{o}$ deny an exemption to claimants who engage in certain forms of speech is in effect to penalize them for such speech .... The appellees are plainly mistaken in their argument that, because a tax exemption is a 'privilege' or 'bounty,' its denial may not infringe speech." ${ }^{296}$ Similarly, in Keyishian v. Board of Regents (1967), ${ }^{297}$ the plaintiffs, faculty members at a state university in New York, had been let go at the end of their employment contracts or had been informed they would be dismissed for their refusal to sign certificates stating that they were not presently Communists and had notified the president of the State University of New York if they had ever been Communists in the past. ${ }^{298}$ The Supreme Court struck down this policy as well, explaining that " "the theory that public employment which may be denied altogether may be subjected to any conditions, regardless of how unreasonable, has been uniformly rejected." "299 "'It is too late in the day to doubt that the liberties of religion and expression may be infringed by the denial of or placing of conditions upon a benefit or privilege." " 300

Barbara James's claim in Wyman could have easily fit into this line of reasoning. The New York policy that she challenged conditioned her receipt of public benefits from the ADC program on her agreement to waive constitutional rights she would otherwise possess, namely the Fourth Amendment right to bar government agents from searching her home without a warrant. Moreover, the facts of Wyman, perhaps even more dramatically than those of Speiser or Keyishian, amply supported the key insight behind the notion that conditioning a public benefit on the waiver of constitutional rights should raise a constitutional question. James was not forced to apply for or collect ADC, but she had extremely compelling reasons to do so. After all, James was eligible to receive ADC precisely because she and her infant son had no other financial resources available to them. ${ }^{301}$ Conditioning the receipt of this benefit on the waiver of constitutional rights functionally operated (here, as in Speiser or Keyishian) in a way that was similar to a penalty imposed on James for asserting her Fourth Amendment rights, which of course would be subject to (probably successful) constitutional challenge. Indeed, because James was under such tremendous pressure to forfeit her rights, because she had so few other realistic options, New York's policy functionally resembled (although of course it was not

295. See id. at 514-15.

296. Id. at 518 .

297. 385 U.S. 589 (1967).

298. See id. at 591-92. One additional plaintiff, a nonfaculty library employee, was fired when he refused to answer the question: "'Have you ever advised or taught or were you ever a member of any society or group of persons which taught or advocated the doctrine that the Government of the United States or of any political subdivisions thereof should be overthrown or overturned by force, violence or any unlawful means?" $I d$. at 592 .

299. Id. at 605-06 (quoting Keyishian v. Bd. of Regents, 345 F.2d 236, 239 (2d Cir. 1965)).

300. Id. at 606 (quoting Sherbert v. Verner, 374 U.S. 398, 404 (1963)).

301. See Wyman v. James, 400 U.S. 309, 313-15 (1971). 
precisely the same as) a direct government order that simply denied James protection against warrantless searches outright.

But the Supreme Court decided the Wyman case on wholly different terms, which would make it all but impossible to mount a successful constitutional challenge against government programs that condition the provision of aid to poor families on their surrender of privacy and autonomy. The Wyman Court held that a mother's agreement to allow an ADC caseworker to visit her home was fully voluntary, so that the caseworker's visit was not a search at all within the meaning of the Fourth Amendment. ${ }^{302}$ As the Court explained, any mother receiving $\mathrm{ADC}$ who did not want a state worker to visit her home could simply refuse to agree to the visit, without fear of criminal prosecution: "If consent to the visitation is withheld, no visitation takes place." ${ }^{303}$ To be sure, such an act would result in the state terminating the aid on which the family relied for its support, but the Court held that this penalty did not change the fundamentally voluntary nature of the transaction or raise a constitutional issue. ${ }^{304}$

This was not the conception of consent and coercion that appeared to be driving the Speiser and Keyishian decisions, although it did have some deep historical roots in the jurisprudence of family law. Common law courts and commentators had long defended the application of marital status rules, which fixed marital rights and duties in the law and made them unchangeable by private agreement, by explaining that married people had voluntarily subjected themselves to these rules when they agreed to marry. This argument about voluntariness had dismissed as irrelevant any economic or social pressure that may have pushed women, in particular, into marriage. ${ }^{305}$ It had not been traditionally applied in the parent-child context, presumably because it would be difficult to characterize a child as having voluntarily agreed to his birth to his biological parents. But the Court drew on a similar conception of voluntariness in Wyman, where aid was at stake. States, in the Court's interpretation of the Constitution, were free to use the provision and denial of financial support to subject families on ADC to nonnegotiable requirements, even if the form the intervention took was wholly at odds with the norms conventionally associated with the law of parent and child, and the constitutional protection of the home.

Indeed, the Wyman opinion took the notion that different rules should apply to families receiving ADC as a matter of common sense. After finding that the required home visits were not searches within the meaning of the Fourth Amendment, the Court went on to note that even if the required visits did "somehow" constitute involuntary searches (even if, in other words, they did trigger constitutional scrutiny under something like an unconstitutional conditions theory), they ultimately raised no constitutional objection under the Fourth

302. See id. at $317-18$.

303. Id.

304. See id.

305. See Hasday, supra note 231 , at $1386-88,1398-1400$. 
Amendment because they were reasonable. ${ }^{306}$ The Court based this latter judgment on two somewhat contradictory arguments. The first contended that New York needed the right to require home visits in order to make sure that mothers receiving ADC were not committing fraud, endangering their children, or otherwise behaving improperly. ${ }^{307}$ The second asserted that mothers subjected to home visits by ADC caseworkers only benefitted from these visits and had nothing to fear, because the caseworker was "not a sleuth but rather, we trust, ... a friend to one in need," dispensing helpful advice and assistance. ${ }^{308}$ Despite their crosscutting impulses, both arguments were ultimately grounded in the assumption-never stated but adopted as a matter of course-that the fact that a mother was receiving ADC was grounds to suspect that she needed outside supervision and guidance to monitor and improve her behavior.

After all, parents who receive other government benefits (like Social Security, to cite a prominent example examined earlier) ${ }^{309}$ have never been routinely subjected to home visits. Certainly, those programs also raise the possibility that families will obtain government funds through fraud, or that the aid provided through those programs will be used to support families in which children are subject to dangerous or simply mediocre parenting. But a program like Social Security does not automatically presume that every one of its recipients is liable to be fraudulent, or abusive, or incompetent at any moment, even though the families it serves are facing the stresses created when a breadwinner stops working or dies and are often very eager to receive the relatively generous financial benefits that the Social Security program provides. Any concerns that the Social Security program does have about preventing those problems, moreover, are tempered by a commitment to protecting the family lives of recipients from unnecessary disturbance. Inspections of these families' homes without a warrant would be considered unnecessary and improper intrusions into familial autonomy and privacy. The Wyman Court, in contrast, made no reference to the principles of respect and deference conventionally associated with family law, obviously convinced they did not properly apply in this case. On its view, it was reasonable for the New York ADC program to rely on warrantless searches, without compiling any of the particularized evidence about a specific household that securing a warrant would require. Any mother receiving ADC could reasonably be suspected and scrutinized, automatically.

The argument that the Wyman Court put forth to defend home visits should be deeply familiar, by this point. The authors of the mothers' pension laws, remember, had harbored a very similar suspicion of program recipients; they operated on the conviction that the mothers receiving these pensions could not be trusted to provide adequate care for their children unless forced to stay at

306. Wyman, 400 U.S. at 318.

307. See id. at 318-19.

308. Id. at 322-23.

309. See supra text accompanying notes $270-79$. 
home, but they were equally certain that recipients could not be trusted with adequate funds to enable them to stay home. ${ }^{310}$ The Wyman decision al'so resembles the line of legal regulation extending from the child cruelty societies to the TANF program in that its commitment to the bifurcation in the legal regulation of parenthood-its certainty that poor families without a father able to support them do not merit the deference otherwise accorded to a parent's household government-is more deeply felt, than fully explained. When the Wyman decision all but precluded successful constitutional challenges to this bifurcated regime, it ensured that future cases, and the legal and political decision makers who follow them, would have little cause to consider the issue in more depth.

The unconstitutional conditions doctrine has survived in a number of arenas since Wyman, although none of these cases appears to raise pressing issues of class, race, or gender. Where the property rights of landowners are at issue, for instance, the Supreme Court has held that a government cannot condition approval of a building permit on the property owner's agreement to dedicate a portion of her land to flood control and traffic improvements, ${ }^{311}$ or on the owner's agreement to give the public an easement across her beachfront property. ${ }^{312}$ With the free speech rights of the media at stake, the Court has ruled that a government cannot condition a tax exemption for periodicals on the subject matter of the magazine, ${ }^{313}$ or condition funding to a noncommercial educational broadcasting station on the station's agreement not to engage in editorializing. ${ }^{314}$ Public employees have also been successful with unconstitutional conditions arguments, with the Court finding that a government cannot condition public employment on the surrender of the due process right to notice and an opportunity to respond before termination, ${ }^{315}$ or condition continued

310. See supra text accompanying notes $220-24$.

311. See Dolan v. City of Tigard, 512 U.S. 374, 377, 396 (1994); id. at 385 ("Under the well-settled doctrine of 'unconstitutional conditions,' the government may not require a person to give up a constitutional right-here the right to receive just compensation when property' is taken for a public use-in exchange for a discretionary benefit conferred by the government where the benefit sought has little or no relationship to the property.").

312. See Nollan v. Cal. Coastal Comm'n, 483 U.S. 825, 827, 841-42 (1987).

313. See Ark. Writers' Project, Inc. v. Ragland, 481 U.S. 221, 223, 234 (1987); id. at 230 ("If articles in Arkansas Times were uniformly devoted to religion or sports, the magazine would be exempt from the sales tax under $\$ 84-1904(\mathrm{j})$. However, because the articles deal with a variety of subjects (sometimes including religion and sports), the Commissioner has determined that the magazine's sales may be taxed."). .

314. See FCC v. League of Women Voters, 468 U.S. 364, 366, 402 (1984).

315. See Cleveland Bd. of Educ. v. Loudermill, 470 U.S. 532, 535, 541, 546-48 (1985); id. at 541 ("'While the legislature may elect not to confer a property interest in [public] employment, it may not constitutionally authorize the deprivation of such an interest, once conferred, without appropriate procedural safeguards."' (quoting Arnett v. Kennedy, 416 U.S. 134, 167 (1974) (Powell, J., concurring in part and concurring in result in part))). However, the government is free to terminate public employees "without the full panoply of rights which attend a trial-type adversary hearing." See Amett, 416 U.S. at 151 (plurality opinion). 
public employment on membership in a particular political party. ${ }^{316}$
But constitutional challenges since Wyman to the bifurcation in the law of
parental relations have been summarily rejected, ${ }^{317}$ on the ground-crucial to

316. See Elrod v. Burns, 427 U.S. 347, 349, 360-61, 373 (1976) (plurality opinion); id. at 361 ("The denial of a public benefit may not be used by the government for the purpose of creating an incentive enabling it to achieve what it may not command directly.").

317. There are four successful right-to-travel or citizenship cases that might be considered exceptions to this proposition. But, ultimately, I think that they are not properly classified as challenges to the law's bifurcated treatment of parental relations. Decided before Wyman, Shapiro v. Thompson, 394 U.S. 618 (1969), held that a state could not condition eligibility for welfare assistance like ADC on an applicant's one-year residence in the state, see id. at 621-22 \& n.1, 641-42. Memorial Hospital $v$. Maricopa County, 415 U.S. 250 (1974), similarly held that a state could not condition eligibility for free nonemergency medical care on an indigent's one-year residence in the county where he sought care, see id. at 251, 269-70. Most recently, Saenz v. Roe, 526 U.S. 489 (1999), held that a state could not condition eligibility for full TANF benefits on an applicant's one-year residence in the state, even if the state provided the applicant with the amount of TANF benefits that she would have received had she remained in her prior state of residence, see id. at 492-93, 495-96, 507-08. Along the same basic lines, Graham v. Richardson, 403 U.S. 365 (1971), held that a state could not condition eligibility for welfare benefits upon United States citizenship or require aliens to have spent a specified number of years in the United States, see id. at 366, 376, 380.

In my opinion, however, none of these cases squarely implicates the divide in the law of parental relations. Indeed, they do not seem particular to the welfare context at all. To be sure, the statutes challenged in Shapiro, and perhaps those at issue in some of the other cases as well, placed financial pressure on parents receiving welfare to stay in their current state of residence. But none of these statutes appears to have been motivated by a desire to subject families associated with failed fatherhood to special forms of suspicion and interference not applied to the households of more successful family men, which is the key normative hallmark of the legal tradition extending from the child cruelty societies to the Personal Responsibility Act. Instead, states defended the statutes at issue in these cases with variations on the same essential argument that they have employed to defend the lower tuition rates that public universities offer to students who have resided in the state for a specified amount of time or that Alaska, in particular, has used to defend a dividend distribution program according preferential treatment to established state residents: namely, that a state has a legitimate interest in favoring its own long-time residents in distributing limited resources and will best be able to offer generous benefits to those residents if it can prevent newcomers from immediately claiming an equal share and raising the state's total costs in a way thought to be undesirable or unfair. See Saenz, 526 U.S. at 497; Memorial Hospital, 415 U.S. at 263; Graham, 403 U.S. at 372; Shapiro, 394 U.S. at 627-28. The Supreme Court almost always rejects this sort of argument, in the welfare context and out. See, e.g., Zobel v. Williams, 457 U.S. 55, 56, 65 (1982) (striking down Alaskan statutory scheme that distributed income derived from the state's natural resources to the adult citizens of the state in varying amounts based on the length of each citizen's residence in the state); Vlandis v. Kline, 412 U.S. 441, 452 (1973) (holding that state university cannot deny a student in-state tuition rates on the basis of a permanent and irrebutable presumption of nonresidence).

In addition, there is one case, United States Department of Agriculture v. Moreno, 413 U.S. 528 (1973), that might be considered closer to a successful constitutional challenge to an aspect of the bifurcated law of parenthood. Moreno considered the constitutionality of a federal statute that excluded from the food stamp program any household containing an individual who was unrelated to any other member of the household. See id. at 529. The statute created enormous incentives for households to restructure themselves. See id. at 537-38. In that sense, it was quite typical of the interventionist norms that the law has repeatedly applied to families associated with dependency and failed fatherhood, although, in fact, the statute's legislative history indicates that the law was actually passed "to prevent so-called 'hippies' and 'hippie communes' from participating in the food stamp program." Id. at 534.

In Moreno, the Court struck down this statute. See id. at 538. That result stands in important contrast to Wyman, as well as to the cases discussed below. See infra notes 318-49 and accompanying text. At the same time, the Moreno Court did not rely on a theory of unconstitutional conditions, or hold that 
the Wyman decision as well-that the disputed policies affected only voluntary behavior and hence could not infringe upon any constitutional rights at all. Consider how the Supreme Court quickly disposed of two challenges to policies that conditioned some welfare benefits on the restructuring of familial relations. In Lyng v. Castillo (1986), ${ }^{318}$ the Supreme Court held that it raised no constitutional issues for the federal food stamp program, which provided subsidized food vouchers to $\mathrm{ADC}$ recipients and other poor families, to deny or reduce benefits to closely related families that lived together, but generally bought their food and prepared their meals separately. ${ }^{319}$ Such a statutory scheme placed tremendous financial pressure on poor people to reorder their family lives so that all closely related families residing in the same house ate together. But the Court found, nonetheless, that the law did not "'directly and substantially' interfere with family living arrangements and thereby burden a fundamental right" because it did not actually "order or prevent any group of persons from dining together." ${ }^{320}$ Along the same lines, Bowen v. Gilliard $(1987)^{321}$ held that the federal government could structure the ADC program so that some families would have significantly greater financial resources available to them if the mother sent one or more of her children to live in another household. ${ }^{322}$ The

any fundamental rights of privacy or liberty were infringed upon by the challenged law. It simply ruled that the particular statutory classification at issue failed the rational basis test applied to every law passed by Congress because there was no rational reason to believe that the rule would serve the food stamp program's purposes of improving nutrition among low-income households and supporting the agricultural industry or that it would help to minimize fraud in the program. See Moreno, 413 U.S. at 533-38.

318. 477 U.S. 635 (1986).

319. See id. at $636-43$.

320. Id. at 638 (quoting Zablocki v. Redhail, 434 U.S. 374, 386-87 \& n.12 (1978)). The Castillo Court also noted that it was "exceedingly unlikely that close relatives would choose to live apart simply to increase their allotment of food stamps, for the cost of separate housing would almost certainly exceed the incremental value of the additional stamps." Id.

Lyng $v$. International Union, 485 U.S. 360 (1988), was decided in very similar terms. This case considered the constitutionality of a federal statute that prohibited households from entering the food stamp program while any member of the household was on strike and that denied households already enrolled in the food stamp program any additional benefits needed because the income of the striking member had decreased. See id. at 362. In upholding the law, the Court explained that:

it is "exceedingly unlikely" that [the challenged statute] will "prevent any group of persons from dining together." Even if isolated instances can be found in which a striking individual may have left the other members of the household in order to increase their allotment of food stamps, "in the overwhelming majority of cases [the statute] probably has no effect at all." The statute certainly does not "order" any individuals not to dine together; nor does it in any other way " directly and substantially interfere' with family living arrangements."

Id. at 365-66 (quoting Castillo, 477 U.S. at 638).

321. 483 U.S. 587 (1987).

322. More specifically, Bowen challenged an amendment to the federal laws governing ADC that conditioned receipt of ADC on the parent's agreement to assign to the state the right to receive child support payments for any child living in the parent's household. See id. at 589-94. The net effect of this amendment was to reduce the overall financial resources of most families on ADC who had been receiving child support payments for at least one child, a loss that a family could only recover by sending the child for whom child support was being received to live elsewhere. See id. at 594, 601-02. 
Court concluded that such a statute presented no constitutional questions either, because a mother making such a choice was acting freely: "That some families may decide to modify their living arrangements in order to avoid the effect of" such a policy, the Court reasoned, "does not transform the [law] into an act whose design and direct effect are to "intrud[e] on choices concerning family living arrangements."

Having determined that no constitutional rights could be infringed upon by these two statutory schemes, the Court felt the need to only briefly state why it was altogether reasonable for Congress to regulate family relationships among recipients of welfare benefits in this way. As in Wyman, the Court relied heavily on conclusory (but historically resonant) justifications steeped in suspicion and worries about fraud, while simultaneously denying that the challenged policies would have an adverse effect on the family life of the people affected. It explained in Castillo, for instance, that "the Legislature's recognition of the potential for mistake and fraud and the cost-ineffectiveness of case-by-case verification of claims that individuals ate as separate households unquestionably warrant[ed]" Congress's decision to reduce or deny benefits based on the categorical assumption that closely related families living in the same house bought their food and prepared their meals together. ${ }^{324}$ The Court saw no cause to elaborate on the reasons why concerns about fraud should loom so large as a rationale for the law's treatment of family relations among recipients of food stamps, when such worries do not play nearly as large a role in other programs that distribute benefits to family members but are not popularly associated with economic dependency or failed fatherhood. ${ }^{325}$ That fact was taken as a given, here as in Wyman, as was the proposition that it was unremarkable and untroubling for the government to use the provision and denial of aid as a means of pushing families receiving stigmatized benefits like food stamps into reordering the internal structures of their familial relationships. With no evident qualm or nod to the norms of deference, respect, and noninterventionism generally understood to characterize the law's treatment of family life, the Court concluded in Castillo that it would be relatively easy and unproblematic "for close relatives ... to accommodate their living habits to a federal policy favoring common meal preparation." ${ }^{326}$

323. Id. at 601-02 (quoting Moore v. City of East Cleveland, 431 U.S. 494, 499 (1977)).

324. Castillo, 477 U.S. at $640-41$.

325. See supra text accompanying notes $270-79$.

326. Castillo, 477 U.S. at 643 . The Court similarly asserted in Bowen that the policy challenged in that case left families receiving ADC better off (compared, of course, to receiving no ADC benefits at all). As the Court explained:

The law does not require any custodial parent to apply for AFDC benefits. Surely it is reasonable to presume that a parent who does make such an application does so because she or he is convinced that the family as a whole-as well as each child committed to her or his custody - will be better off with the benefits than without.

Bowen, 483 U.S. at 608-09. 
Since deciding Wyman, the Court has also employed the mode of argument used to dispose of constitutional challenges to the bifurcated treatment of parental relations more broadly, in litigation that more generally addresses the reproductive rights of poor women. An apt example can be found among the Court's decisions upholding laws that deny poor women access to abortions under Medicaid, a joint federal-state program that provides medical care, including that associated with childbirth, to recipients of ADC or TANF and to other indigent people. Maher $v$. Roe (1977), ${ }^{327}$ for instance, rejected a constitutional challenge to a Connecticut regulation that refused to provide poor women who received their medical care through the state Medicaid program with firsttrimester abortions, unless the abortions were "medically necessary.",328 The regulation was explicitly intended to push pregnant women receiving Medicaid into giving birth to a child, ${ }^{329}$ wielding a form of pressure that could only be applied with such intensity to women who were eligible for state-supported health care precisely because they lacked the financial resources to pay for medical procedures like abortions on their own. But the Maher Court held, nonetheless, that the regulation did not impinge upon a woman's constitutional right to have a first-trimester abortion, or create a problematic divide between poor women and privileged women, who would have much greater practical access to abortion services. ${ }^{330}$ Instead, the Court explained, here as in Wyman and its progeny, that the Connecticut regulation raised no such constitutional issues because any steps that a woman took or decisions that she made in light of this law would be fully voluntary and not coerced or created in any way by the state. "An indigent woman who desires an abortion suffers no disadvantage as a consequence of Connecticut's decision to fund childbirth; she continues as before to be dependent on private sources for the service she desires," the Maher Court reasoned. ${ }^{331}$ "The State," the Court continued, "may have made childbirth a more attractive alternative, thereby influencing the woman's decision, but it has imposed no restriction on access to abortions that was not already there." ${ }^{, 32}$ Harris v. McRae $(1980)^{333}$ similarly upheld the constitutionality of a series of federal laws (popularly known as the "Hyde Amendments") that denied states reimbursement for the cost of certain medically necessary abortions that they chose to provide under their Medicaid programs. ${ }^{334}$ Like the Connecticut regulation upheld in Maher, the Hyde Amendments were explicitly designed to use the provision and denial of aid to make it much more difficult for poor women enrolled in the Medicaid program to obtain abortions. ${ }^{335}$ Yet the Court again held that the challenged laws did not infringe upon an indigent

327. 432 U.S. 464 (1977).

328. Id. at $466-67,480$.

329. See id. at $475,478-80$.

330. See id. at 474 .

331. Id.

332. Id.

333. 448 U.S. 297 (1980).

334. See id. at $300-03,326$.

335. See id. at 315 . 
woman's constitutional right to abortion, concluding that the woman's choice remained free and unconstrained by the state: "Although Congress has opted to subsidize medically necessary services generally, but not certain medically necessary abortions, the fact remains," the Court explained, "that the Hyde Amendment leaves an indigent woman with at least the same range of choice in deciding whether to obtain a medically necessary abortion as she would have had if Congress had chosen to subsidize no health care costs at all."336

But the record of the recent litigation on the family cap provisions applied to welfare recipients is perhaps the most dramatic illustration of the status, treatment, and interest that courts currently bestow on constitutional cases that challenge the divide in the law of parental relations. This case law has two very notable characteristics. Its first prominent feature is its sparseness. Even before the Personal Responsibility Act of 1996 authorized states to enact family cap provisions in their TANF programs, nineteen states had received waivers from the federal government enabling them to make family caps part of their ADC programs. By October 1997, twenty-two states had family cap policies in place. ${ }^{337}$ All of these provisions, however, have resulted in only two (unsuccessful) legal challenges pursued to the point of a published court opinion, a sign

336. Id. at 316-17; see also Rust v. Sullivan, 500 U.S. 173, 203 (1991) ("Petitioners contend . . . that most Title $\mathrm{X}$ clients are effectively precluded by indigency and poverty from seeing a health-care provider who will provide abortion-related services [since federal law prohibits family planning clinics that receive federal funding under Title $X$ from using those federal funds to provide abortion-related services]. But once again, even these Title $X$ clients are in no worse position than if Congress had never enacted Title X."); Webster v. Reprod. Health Servs., 492 U.S. 490, 509 (1989) ("Missouri's refusal to allow public employees to perform abortions in public hospitals leaves a pregnant woman with the same choices as if the State had chosen not to operate any public hospitals at all.").

The Court did note in Maher that "[i]f Connecticut denied general welfare benefits to all women who had obtained abortions and who were otherwise entitled to the benefits, ... strict scrutiny might be appropriate." 432 U.S. at 474-75 n.8. It similarly remarked in Harris that "[a] substantial constitutional question would arise if Congress had attempted to withhold all Medicaid benefits from an otherwise eligible candidate simply because that candidate had exercised her constitutionally protected freedom to terminate her pregnancy by abortion." 448 U.S. at 317 n.19. On the Court's view, either of these imagined regimes of exclusion might count as a "penalty" imposed for exercising a constitutional right, rather than simply "a refusal to subsidize" the exercise of that right. Maher, 432 U.S. at 474-75 n.8; Harris, 448 U.S. at 317 n.19. It is not clear what underlies this judgment and proposed distinction. Certainly, the logic of voluntariness that the Court deployed in Maher and Harris could be extended to uphold the Court's imagined statutes. The Court could reason in these future cases, as it did in Maher and Harris, that pregnant indigent women exercise a legally free choice in deciding whether to have an abortion, because the state does not actually compel them to carry their fetuses to term. To be sure, the indigent pregnant women who do choose to have an abortion will never again be eligible for general welfare benefits and/or Medicaid. But the logic of Maher and Harris might indicate that this result should be understood as leaving those women no worse off than if general welfare benefits and/or the Medicaid program had never existed. All that said, however, the Court's decision to raise constitutional questions about these imagined regulatory regimes does suggest that the Court thinks that there has to be some limit to its arguments from voluntariness.

337. See Gallagher ET AL., supra note 263, at VI-8 ("15 [states] had a family cap in place prior to the passage of PRWORA [the Personal Responsibility Act] in August 1996. The other 7 states did not implement a family cap until after PRWORA, however all but 3 states . . had received permission for a family cap under waivers."); Office of the Assistant Secretary for Planning and Evaluation, Dep't of Health and Human Services, Setting the Baseline: A Report on State Welfare Waivers 6 (1997). 
that potential plaintiffs recognize the difficulties that such suits confront ${ }^{338}$ The second striking feature of this case law, linked to the first, is how little attention it devotes to the normative premises underlying the family cap policies in the absence of a live constitutional question as to their legal validity.

Consider, for instance, the opinion that the U.S. Court of Appeals for the Third Circuit issued in C.K. v. New Jersey Department of Health and Human Services (1996), which rejected a challenge to New Jersey's family cap policy. ${ }^{339}$ This policy, initiated under waiver in $1992,{ }^{340}$ provided that families entering the ADC program would receive (somewhat) more aid for each additional child they contained, reflecting the added costs of raising more children. However, families would not receive any more aid from the New Jersey ADC program to cover the costs of an additional child, if that child was conceived and born while her mother was already receiving ADC. ${ }^{341}$ The policy explicitly intended to use the state's power over the financial support it granted and denied as a means of influencing the reproductive decisions of women receiving ADC. Specifically (and in this way unlike the antiabortion legislation upheld in Maher and Harris), ${ }^{342}$ it sought to give women receiving ADC a stark incentive not to have more children. Indeed, in its application to the federal government for a waiver to implement the family cap policy, the New Jersey Department of Health and Human Services "explicitly described the choice to have a child while receiving public support as "irresponsible [and] not socially desirable." ${ }^{343}$ Plaintiffs, a class consisting of individuals in families subject to the New Jersey family

338. See C.K. v. N.J. Dep't of Health \& Human Servs., 92 F.3d 171 (3d Cir. 1996), aff'g 883 F. Supp. 991 (D.N.J. 1995); N.B. v. Sybinski, 724 N.E.2d 1103 (Ind. Ct. App. 2000). A New Jersey Superior Court judge also issued an oral decision in August 2000 rejecting a challenge to the state's family cap provisions that was brought under the New Jersey Constitution. The plaintiffs had contended that the family cap policy in New Jersey violated the state's equal protection guarantee and interfered with a woman's fundamental right under the state constitution to decide whether to have additional children. See Randall J. Peach, Judge Upholds N.J.'s Welfare Cap Linked to Birth of Added Children, N.J.L.J., Sept. 4, 2000, at 8 (reporting oral decision in Sojourner A. v. N.J. Dep't of Human Servs., No. ESX-L-10171-97 (N.J. Super. Ct. Law Div. Aug. 30, 2000)); Appeal Likely on Welfare Cap, N.J. Law., Sept. 4, 2000, at 2 (reporting that plaintiffs expect to appeal).

A class of plaintiffs recently had more success challenging the administration of the family cap program in Nebraska, but this suit only contested the way in which the Nebraska Department of Health and Human Services had interpreted the state's family cap law. In Mason v. State, No. CI 00-3389 (Neb. Dist. Ct. Oct. 26, 2001), all of the named adult plaintiffs were mothers who received ADC payments for the support of some of their children, but received federal Supplemental Security Income for themselves because they suffered from recognized disabilities that prevented them from working, see slip op. at 1-3. These plaintiffs successfully established that the statutory provision creating Nebraska's family cap policy was not meant to apply to families like their own, with a parent who is unable to work. See id. at 9-11.

339. See C.K., 92 F.3d at $177-78,195$.

340. See id. at 177.

341. See id. at 179 ("The provision challenged in this action is section 3.5 of the chapter, an amendment to then-existing state law that eliminates the standard AFDC grant increase (e.g., \$102 for a second child and $\$ 64$ for a third child) for any child conceived by and born to an AFDC recipient.").

342. See supra text accompanying notes $327-36$.

343. C.K., 92 F.3d at 180 (quoting App. at 183). 
cap, ${ }^{344}$ challenged the policy on statutory, regulatory, and constitutional grounds. ${ }^{345}$ Most of their arguments fell in the first two categories, however, an acknowledgment of how difficult it is to raise a successful claim under the current constitutional framework. ${ }^{346}$

The Court of Appeals, for its part, quickly disposed of the plaintiffs' claims under the Due Process and Equal Protection Clauses, after also rejecting their statutory and regulatory contentions. It explained, employing a logic deeply reminiscent of the Wyman opinion and its Supreme Court progeny, that New Jersey's family cap placed no burden on reproductive choice and was, instead, "neutral with respect to that choice." ${ }^{347}$ This was the case, the court held, because the New Jersey policy that denied additional aid to mothers who had another child while receiving ADC, also did not provide additional aid to mothers who had no more children while on ADC. Either way, whether a woman had more children or not, she received no increase in financial support. A woman's decision about whether to have another child thus remained fully voluntary, free, and uncoerced as a matter of constitutional law, despite the fact that mothers who did have more children while on ADC would be left with less support for each child than even the ADC program otherwise thought appropriate. ${ }^{348}$ The constitutional question effortlessly (if bizarrely) answered, the court saw no need to question or examine the normative validity of subjecting women receiving ADC (or now TANF) to forms of interventionist and instrumental regulation wholly at odds with the norms governing the rest of family law. It was simply a moot issue. ${ }^{349}$

\section{THE NEED FOR NORMATIVE DELIBERATION}

The ease with which our current constitutional regime dismisses legal challenges to the bifurcated regulation of parenthood has discouraged sustained normative debate on the subject. But the lack of realistic constitutional possibilities should not preclude serious reflection about whether the divide in the law of parenthood should persist as a matter of legislative and regulatory policy. Indeed, such reflection is particularly needed in an arena that has been missing

344. See id. at 177 n.l.

345. See id. at 177-78.

346. See id. at 181-94.

347. Id. at 195. In making this determination, the court did not see the need to actually cite any cases, except the district court opinion in the case before it. See id. at 194-95.

348. See id. N.B. v. Sybinski, 724 N.E.2d 1103 (Ind. Ct. App. 2000), rejected a constitutional challenge to Indiana's family cap policy on similar grounds, reasoning that the policy "does not deprive the Class of the right to have children; rather, it merely chooses not to subsidize the increased costs of an additional child," id. at 1110; see also id. at 1109 ("Indiana has done nothing to bar a TANF recipient from keeping a capped child in the home; rather, the State has merely chosen not to subsidize the parents' fundamental right by removing the automatic benefit increase associated with an additional child under the AFDC program."); $i d$. ("The fact that some families may choose to remove a capped child from their home in order to avoid the effects of the family cap does not give the rule coercive effect and make it unconstitutional.").

349. See C.K., 92 F.3d at 195. 
the forms of deliberation that constitutional adjudication can sometimes supply.

The crucial unexplored question does not concern how much welfare the government should provide, a much discussed subject in recent years. ${ }^{350}$ Instead, it asks why the provision of welfare should be reason to completely alter the legal norms that govern a family's relations. Why should it be the case that a father's failure to provide, together with a mother and child's call for government support through certain tainted programs, is still enough to subject every member of that family to legal rules and presumptions that are interventionist, instrumental, and wholly opposed to those conventionally associated with family law? Why should the law sustain two separate and very different normative regimes for governing parenthood whose application turns on whether money is transferred in this particular social modality?

Constitutional courts and legislative policymakers have hardly begun to frame this question, much less formulate a normative response. In fact, courts have endorsed America's record of dual regimes for governing parenthood with little question. In considering the law's bifurcated treatment of parental relations, they have accepted and reasoned from within the very structure that created the divide.

It may be that one could offer a convincing defense for the current structure of the legal regulation of parenthood. To be honest, I am deeply skeptical that such a defense exists. If the deference that the common law tradition accords to a parent's household government does not adequately recognize a child's right to be protected from parental abuse and excess, the tradition of legal regulation extending from the child cruelty societies to the Personal Responsibility Act evinces an enthusiasm for disrupting parental prerogatives that turns on particular forms of economic failure rather than, for instance, actual evidence of child abuse.

The more important point, however, is that so far we have not even begun to have a sustained national conversation about whether and why the legal treatment of parenthood should be divided as it is now. The bifurcation in America's law of parental relations is widely taken to be a matter of common sense that is beyond the need for rigorous explanation. Yet to the extent that these common sense intuitions rest, as they fundamentally appear to, on the familiarity created by past practice, that history can no longer be taken to provide an adequate

350. For typical statements in this debate, see 141 ConG. Rec. 15,450 (1995) (extended remarks of Rep. Cunningham) ("'The spending on welfare, food stamps, AFDC, and others must decrease. These programs have increased to $54 \%$ of the total federal budget with no end in sight. If this spending continues on the same course, you will authorize spending of all our tax dollars on programs that are designed to help only a fraction of our nation's population." (quoting a "Contract from Americans" received from constituents)); and Robert C. Fellmeth, Beyond the Buzzwords, What Reform Really Means, L.A. Times, Nov. 24, 1995, at B7 ("Child advocates wonder why some people are so outraged over the $1.5 \%$ of the federal budget spent on AFDC, given the much larger waste on corporate subsidies, and the expenditure of 20 times this amount on the elderly."). 
justification. Many of the reasons historically offered for the divide's creation and maintenance would not convince large numbers of modern Americans. Indeed, the impulses behind the creation and maintenance of the bifurcation in the law's treatment of parental relations have frequently reflected a vision of class, race, and gender that portions of our contemporary legal and constitutional culture actively repudiate in other contexts. We can no longer comfortably rely on the long record of past practice to explain and perpetuate the bifurcation in the law of parenthood. The time for serious deliberation about the divide is long overdue. 